\title{
Análise de ferramentas computacionais para planejamento estratégico do uso do solo e transportes
}

Dissertação apresentada à Escola de Engenharia de São Carlos da Universidade de São Paulo, como parte dos requisitos para a obtenção do título de Mestre em Ciências, Programa de Pós-Graduação em Engenharia de Transportes.

Área de concentração: Planejamento e Operação de Sistemas de Transporte.

Orientador: Prof. Dr. Antônio Nélson Rodrigues da Silva. 


\begin{abstract}
AUTORIZO A REPRODUC̃̃̃ E DIVULGACÃO TOTAL OU PARCIAL DESTE TRABALHO, POR QUALQUUER MEIO CONVENCIONAL OU ELETRÔNICO, PARA FINS DE ESTUDO E PESQUISA, DESDE QUE CITADA A FONTE.
\end{abstract}

Ficha catalográfica preparada pela Seção de Tratamento da Informação do Serviço de Biblioteca - EESC/USP

Rocha, Gustavo Rennó
R672a Análise de ferramentas computacionais para

planejamento estratégico do uso do solo e transportes / Gustavo Rennó Rocha ; orientador Antônio Nélson Rodrigues da Silva. -- São Carlos, 2010.

Dissertação (Mestrado-Programa de Pós-Graduação em Engenharia de Transportes. Área de Concentração em Planejamento e Operação de Sistemas de Transportes -- Escola de Engenharia de São Carlos da Universidade de São Paulo, 2010 .

1. Planejamento estratégico. 2. Uso do solo.

3. Demanda por transporte. 4. Países em desenvolvimento.

5. Ferramentas de planejamento. I. Título. 


\section{Resumo}

A constante ausência de planejamento urbano nos países em desenvolvimento é um dos principais fatores responsáveis pela ineficiência da infraestrutura pública de suas cidades, o que é agravado pelo fato de que muitas dessas cidades permanecem em processo de crescimento. Essa falta de planejamento gera inúmeros problemas, principalmente com relação à mobilidade e ao transporte, que por sua vez desencadeiam uma série de outros problemas. Dentre as principais limitações do planejamento sob tais condições, destaca-se a falta de ferramentas apropriadas. Propõe-se assim a caracterização de um modelo para o planejamento estratégico do uso do solo e transportes, com o qual é realizada uma aplicação na cidade de São Carlos, utilizando dados e ferramentas disponíveis. Dessa forma, são analisados os procedimentos executados tanto do ponto de vista técnico do planejamento, quanto do ponto de vista operacional das ferramentas e programas utilizados. Com isso, busca-se construir uma base referencial no sentido de auxiliar o uso, adaptação e desenvolvimento de ferramentas computacionais de planejamento urbano, principalmente para aplicações em cidades médias de países em desenvolvimento e com enfoque no transporte por ônibus. Baseando-se nas principais técnicas de planejamento compatíveis com essa abordagem, o modelo foi definido através de etapas sequenciais, desde a preparação dos dados reunidos, a projeção geográfica de futuros usos do solo, até a previsão e visualização da demanda por transporte urbano. Desse modo, utilizando apenas dados de fácil obtenção, como as informações do Plano Diretor, dados censitários e levantamentos de outras fontes confiáveis, é possível avaliar o impacto do crescimento urbano sobre o sistema de transportes. Para executar o modelo, fez-se uso dos programas What if? e TransCAD, trabalhando os dados através de seus Sistemas de Informações Geográficas e com o eventual auxílio de planilhas eletrônicas. Através da aplicação, o modelo produziu dois cenários distintos, representando diferentes padrões de ocupação e viagem, de acordo com as respectivas hipóteses consideradas. A grande diferença entre os resultados obtidos em cada cenário pode ser explicada principalmente pela falta de políticas de incentivo e controle da ocupação do solo. Entretanto, ambos os cenários apresentaram resultados semelhantes em alguns pontos da cidade, representando tendências bastante prováveis para os próximos anos. As ferramentas e procedimentos utilizados mostraram um bom desempenho do modelo, apesar de eventuais detalhes que podem ser aprimorados.

Palavras chave: planejamento estratégico, uso do solo, demanda por transporte, países em desenvolvimento, ferramentas de planejamento. 



\section{Abstract}

The absence of a regular urban planning practice in developing countries is one of the main causes of an inefficient use of the public infrastructures. That is aggravated by the fact that many cities of those countries are still growing. That lack of planning generates many mobility and transportation issues, which in turn result in many other problems. One of the constraints faced by planners to cope with that reality is the unavailability of suitable planning tools. As a consequence, a model for strategic land use-transport planning is proposed in this study. The model is then applied in the city of São Carlos, making use of available data and tools. The procedures applied are analyzed in two ways: from a planning standpoint and also regarding the operational performance of the planning tools and computer packages used. The purpose of the process was to build a reference framework for the use, adaptation and development of computer tools for urban planning, with a clear focus on medium-sized cities of developing countries that rely on buses for urban public transportation. The model was based on available and intensely used planning techniques compatible with the proposed approach. It was defined in sequential steps, from the data collection and treatment, the estimation and spatial distribution of projected urban land uses, to the evaluation and visualization of future urban transport demand. In such a way, it is possible to evaluate the impacts of urban growth on the transport system with data available in the city's Master Plan, census data files and other reliable sources. As the model was implemented in the computer programs What if? and TransCAD, the data used was treated in Geographic Information Systems and electronic spreadsheets. The model application produced two distinct scenarios, which represent different land use distributions and travel patterns resulting from the adopted hypotheses. The main difference found in the results obtained in the scenarios can be explained by the lack of policies for incentive and control of the urban land uses. However, both scenarios have shown similar results in specific points of the city, what suggests some likely trends for the near future. The tools and procedures used have indicated a good overall model performance, although there are details in which improvements can be done.

Keywords: strategic planning, land use, transportation demand, developing countries, planning tools. 



\section{Lista de figuras}

Figura 4.1 - Uso do solo predominante por quadra em São Carlos, 2000............................ 37

Figura 4.2 - Cadastro dos loteamentos de São Carlos, 2010 ............................................. 38

Figura 4.3 - Condições de desenvolvimento urbano para São Carlos, de acordo com os cenários 1 (esquerda) e 2 (direita).

Figura 4.4 - Padrão de crescimento esperado para São Carlos, de acordo com os

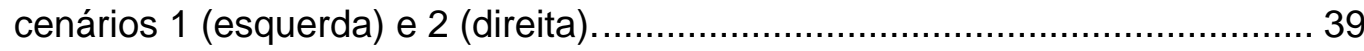

Figura 4.5 - Zonas de análise de tráfego para São Carlos............................................. 40

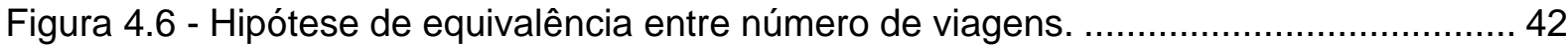

Figura 4.7 - Projeções de uso do solo para São Carlos, 2020......................................... 46

Figura 4.8 - Projeções de uso do solo para São Carlos, 2030........................................ 47

Figura 4.9 - Projeções dos fluxos de viagem por ônibus para São Carlos, 2000................. 48

Figura 4.10 - Projeções dos fluxos de viagem por ônibus para São Carlos, 2020............... 49

Figura 4.11 - Projeções dos fluxos de viagem por ônibus para São Carlos, 2030 .................... 50

Figura 5.1 - Fluxograma geral de procedimentos do modelo proposto. ............................. 52

Figura 5.2 - Simbologia utilizada no Fluxograma. ....................................................... 53

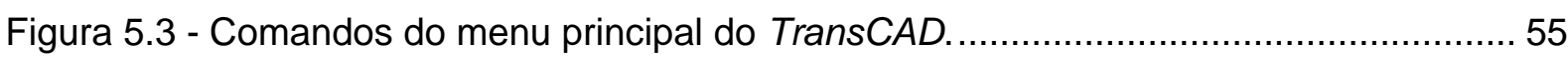

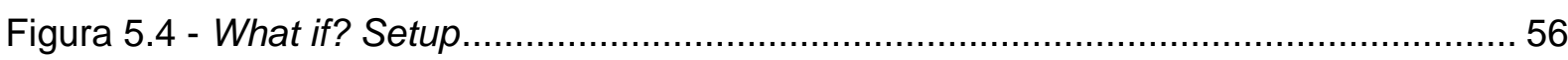

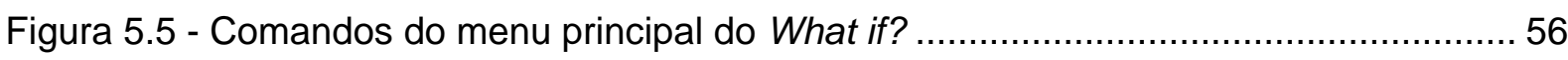

Figura 5.6 - What if? - ferramenta Adequabilidade (Suitability) ....................................... 57

Figura 5.7 - What if? - ferramenta Projeções (Project / Values)...................................... 58

Figura 5.8 - What if? - ferramenta Demanda (Demand) ................................................ 59

Figura 5.9 - What if? - ferramenta Alocação do Uso do Solo (Allocation). ............................ 60

Figura 5.10 - TransCAD - ferramenta Balanceamento de Vetores (Planning / Balance)........ 64

Figura 5.11 - TransCAD - ferramenta Modelo Gravitacional

(Planning / Trip distribution / Gravity application).

Figura 5.12 - TransCAD - ferramenta Alocação Tudo ou Nada

(Planning / Traffic assignment - Method: All or nothing).

Figura 5.13 - TransCAD - ferramenta Mapa Temático com Classificação por Cores (Map / Color theme). 70

Figura 5.14 - TransCAD - ferramenta Mapa Temático com Classificação por Objetos em Escala (Map / Scaled-symbol theme).

Figura 5.15 - TransCAD - ferramenta Calibração do Modelo Gravitacional (Planning / Trip distribution / Gravity calibration). 



\section{Sumário}

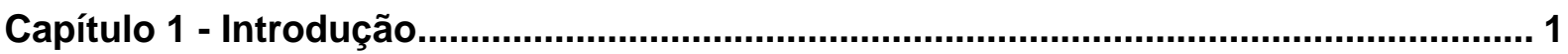

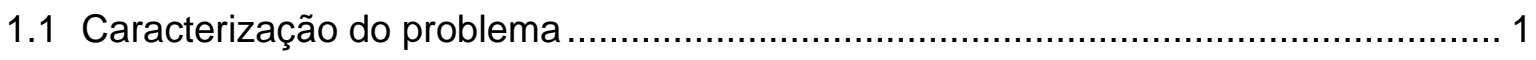

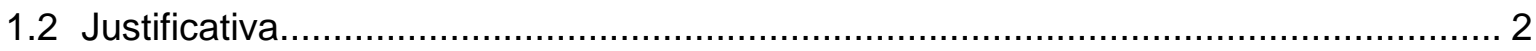

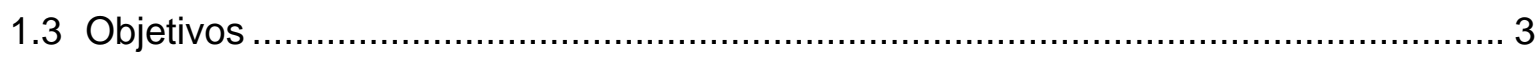

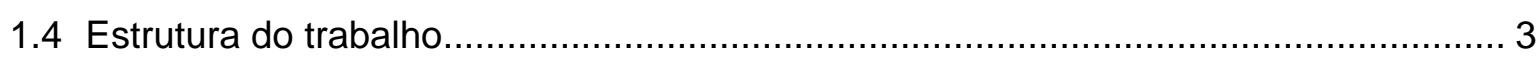

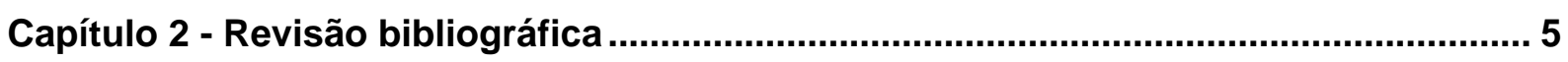

2.1 O processo de urbanização e o crescimento das cidades....................................... 5

2.1.1 A história da urbanização ............................................................................. 5

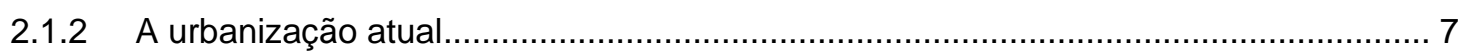

2.2 O planejamento urbano e suas principais vertentes ............................................ 10

2.2.1 O processo de planejamento urbano .................................................................. 10

2.2.2 O Plano Diretor e o Planejamento Estratégico …………....................................... 11

2.3 Técnicas de planejamento urbano e de transportes .......................................... 13

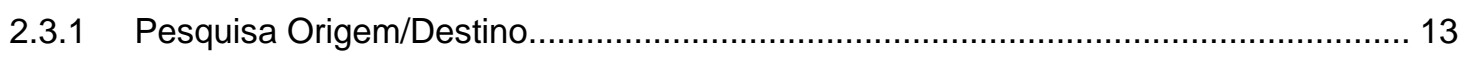

2.3.2 Modelos sequenciais de demanda (quatro etapas) .............................................. 14

2.3.2.1 Primeiro passo: geração de viagens ......................................................... 15

2.3.2.2 Segundo passo: distribuição de viagens .................................................. 15

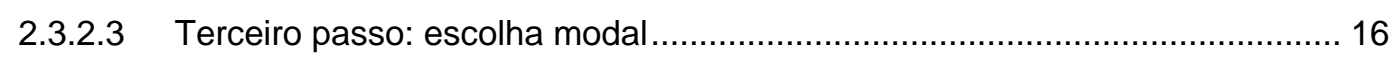

2.3.2.4 Quarto passo: alocação de tráfego.......................................................... 16

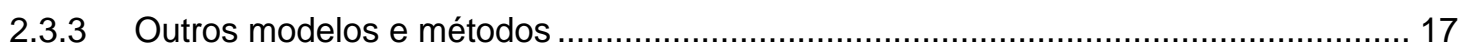

2.3.3.1 Métodos baseados em fatores de crescimento ............................................. 17

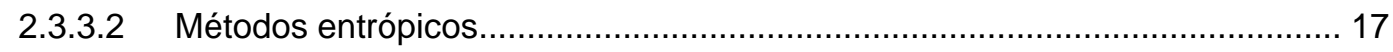

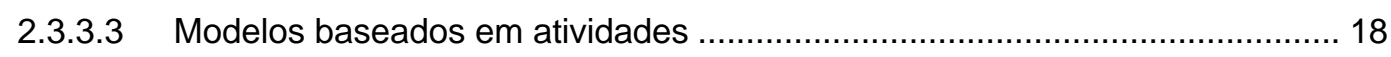

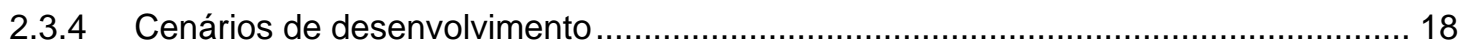

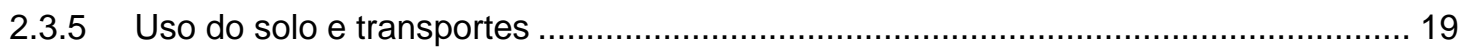

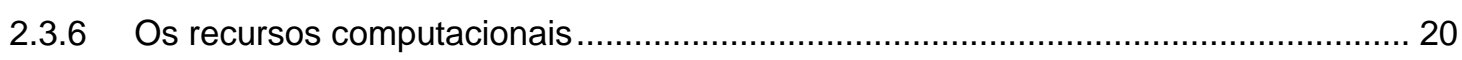

2.3.6.1 Ferramentas computacionais de planejamento urbano para países em

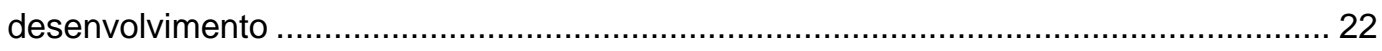

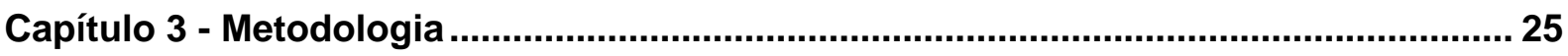

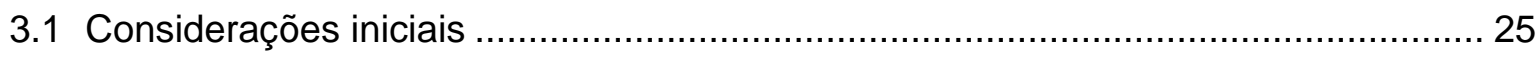

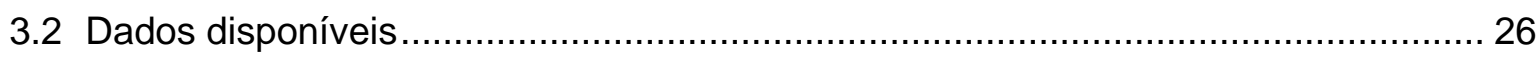

3.2.1 Plano Diretor de Desenvolvimento Urbano...................................................... 27

3.2.2 Instituto Brasileiro de Geografia e Estatística (IBGE) ........................................... 27

3.2.3 Fundação Sistema Estadual de Análise de Dados (SEADE) ................................... 27 


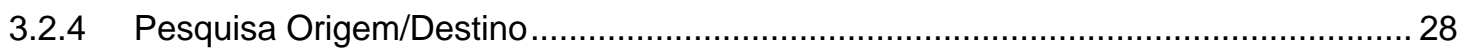

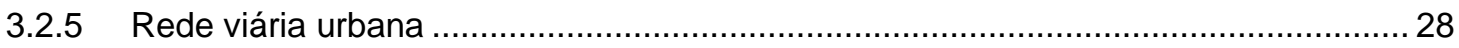

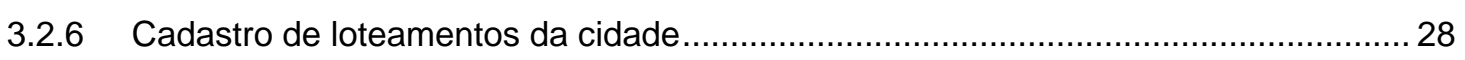

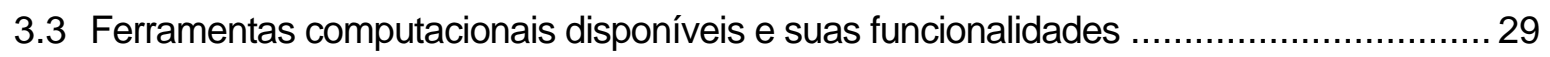

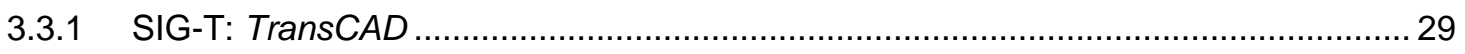

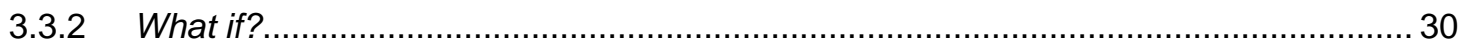

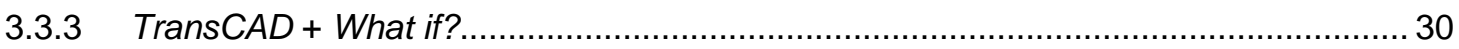

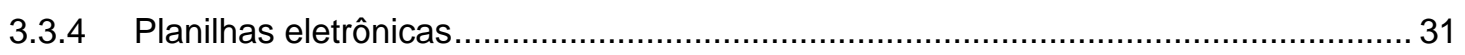

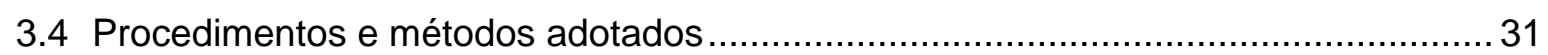

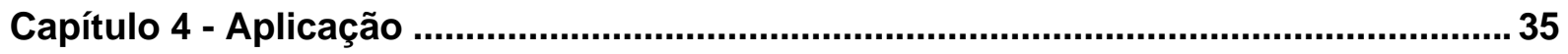

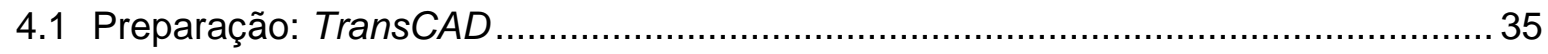

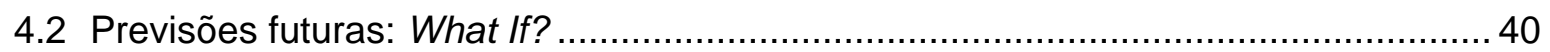

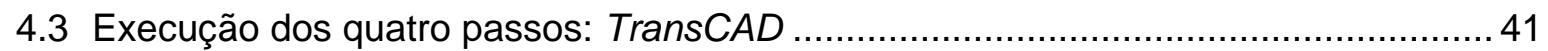

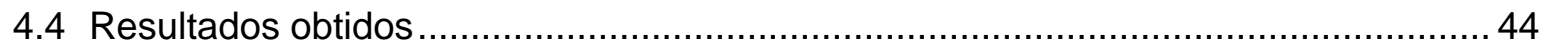

4.4.1 What if?: Cenários futuros de ocupação e uso do solo............................................... 44

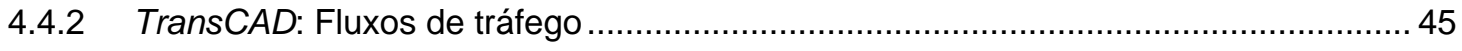

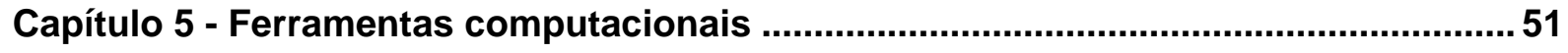

5.1 As ferramentas utilizadas na aplicação do modelo ............................................ 51

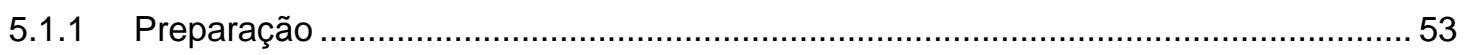

5.1.1.1 Sistema de Informações Geográficas ............................................................... 53

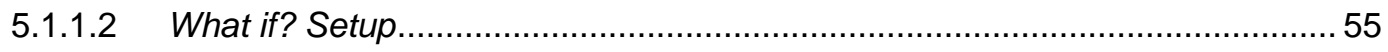

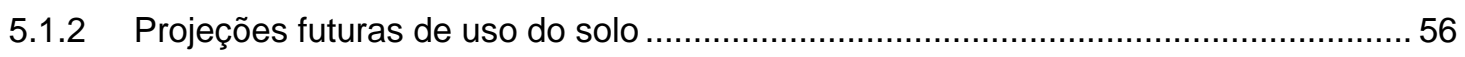

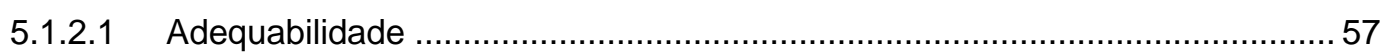

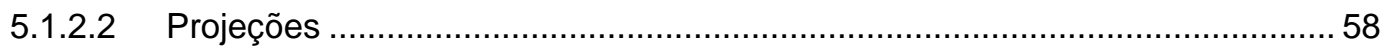

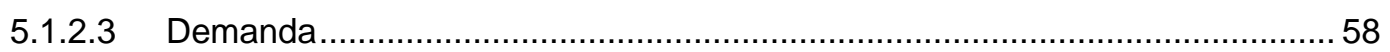

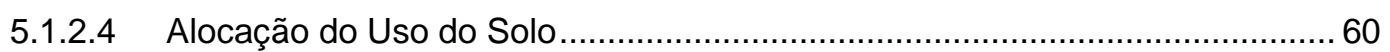

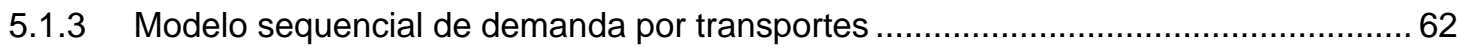

5.1.3.1 Balanceamento de Vetores (Primeiro passo: geração de viagens).................. 63

5.1.3.2 Modelo Gravitacional (Segundo passo: distribuição de viagens) ..................... 64

5.1.3.3 Método de divisão modal (Terceiro passo: escolha modal) ............................ 65

5.1.3.4 Alocação Tudo ou Nada (Quarto passo: alocação de tráfego)......................... 66

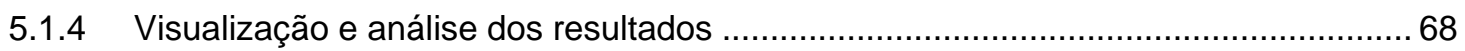

5.1.4.1 Mapa Temático com Classificação por Cores ................................................. 69

5.1.4.2 Mapa Temático com Classificação por Objetos em Escala.............................. 71

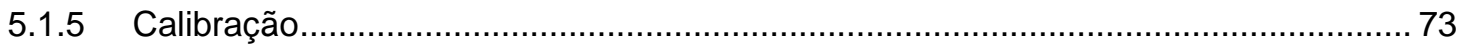

5.1.5.1 Calibração do Modelo Gravitacional ....................................................... 73

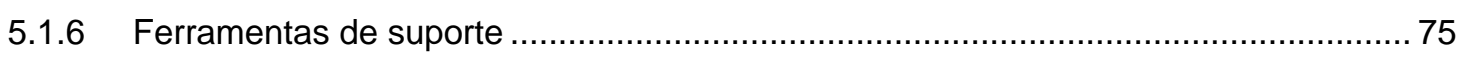

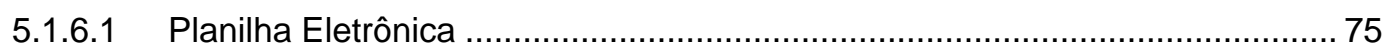




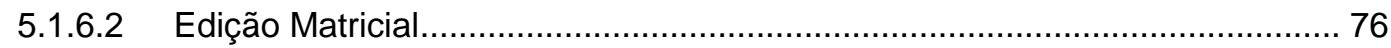

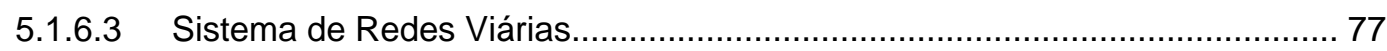

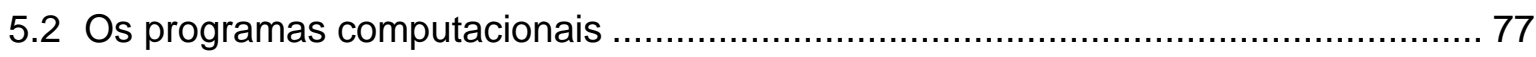

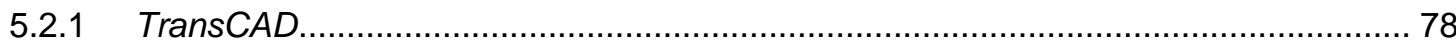

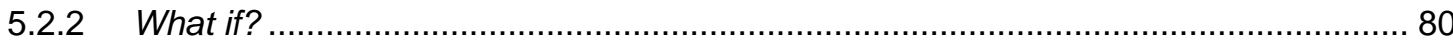

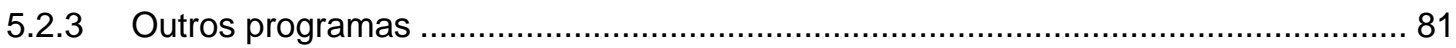

5.3 Adaptação e desenvolvimento de ferramentas e programas................................... 83

5.4 Aplicações e benefícios para o processo de planejamento ....................................... 84

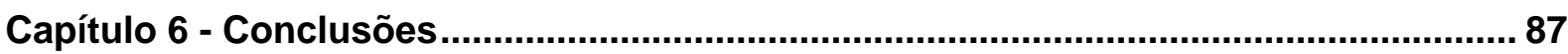

6.1 Conclusões sob o ponto de vista da aplicação .................................................... 87

6.2 Conclusões sob o ponto de vista operacional...................................................... 90

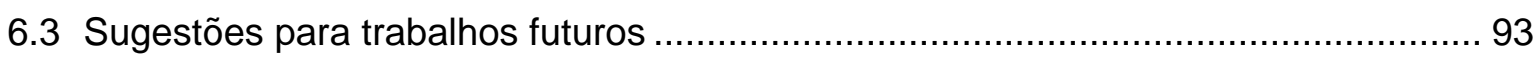

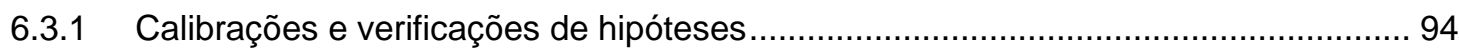

6.3.2 Aplicações com diferentes ferramentas .............................................................. 95

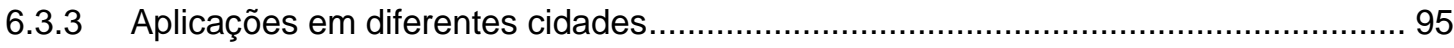

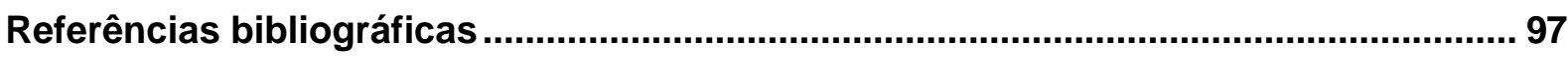





\section{Capítulo 1 - Introdução}

\subsection{Caracterização do problema}

Grande parte das cidades brasileiras apresenta uma característica comum em relação ao desenvolvimento urbano. As áreas urbanas dos municípios, ainda em processo de crescimento, são pouco ou sequer planejadas. Esse fato muitas vezes acarreta deficiências dos sistemas urbanos, principalmente no que diz respeito à mobilidade e ao transporte, geralmente mais visíveis em cidades de médio a grande porte. Essa realidade se aplica a muitas cidades dos países em desenvolvimento, onde a constante falta de recursos e informações desestimula o processo de planejamento por parte dos governos. Estes muitas vezes precisam investir pesadamente em medidas paliativas, quando muito mais eficiente seria investir no planejamento. Isso permitiria a antecipação dos problemas futuros e a execução de medidas preventivas muito menos custosas do que as usuais medidas corretivas, o que proporcionaria melhores condições de vida e um desenvolvimento mais sustentável.

Nesse sentido, as atividades comerciais, industriais, educacionais, recreativas, entre outras, somente são possíveis através do deslocamento de pessoas e produtos, gerando fluxos de viagens urbanas que ocupam diariamente as vias e outras infraestruturas públicas. Essas atividades são essenciais à vida nas cidades, representando fatores importantes para o seu desenvolvimento econômico e social. Sendo assim, o transporte urbano tem fundamental importância no processo de desenvolvimento das cidades (FERRAZ; TORRES, 2004). Deve-se mencionar, ainda, o caráter social do transporte coletivo, ao garantir a mobilidade da população que, por diversos motivos, não pode usufruir de meios de transporte particulares.

Uma maneira de medir os níveis de demanda por transporte é através do número de viagens (número de veículos, número de pessoas, etc.). Portanto, para fins de planejamento, é necessário determinar a quantidade de viagens realizadas no presente e estimar a quantidade de viagens que serão realizadas no futuro. Porém, nesse ponto é importante destacar que o número de viagens realizadas em 
uma determinada cidade estará sempre restrito à capacidade de atendimento da infraestrutura de transporte disponível. Por esse motivo, o número real de viagens não representa fielmente a demanda por viagens, já que indica apenas a quantidade de viagens que o sistema de transporte existente permite realizar (KANAFANI, 1983). Em outras palavras, para evitar que o desenvolvimento urbano seja condicionado a uma infraestrutura inadequada, é preciso investigar o número de viagens que seriam feitas caso houvesse condições satisfatórias. Dessa forma, para que as cidades possam atender convenientemente às suas necessidades de transporte, são necessários métodos de planejamento adequados às condições em que serão aplicados.

\subsection{Justificativa}

Diante desses fatos, fica clara a necessidade de meios que viabilizem um processo de planejamento em transporte urbano de qualidade, compatível à realidade dos países em desenvolvimento. Para isso, é fundamental dispor de ferramentas adequadas, que sejam capazes de executar métodos e modelos, utilizando dados de fácil obtenção e trabalhando com procedimentos de fácil compreensão. Dessa forma, minimiza-se a necessidade de investimentos com o levantamento de dados e com a qualificação de mão de obra especializada. Entretanto, a maioria das ferramentas disponíveis no mercado não prioriza esses aspectos. Além disso, faltam interfaces de visualização atrativas, principalmente quando se trata da apresentação dos resultados. Geralmente se dá prioridade para outros aspectos, também importantes, como a precisão e confiabilidade das informações obtidas, sendo comum o uso de modelos tradicionais de regressão linear, como em Anderson et al. (2006). Porém, com o baixo nível de precisão dos dados que normalmente se têm disponíveis nos países em desenvolvimento, não é vantajosa a utilização de modelos muito precisos, tanto do ponto de vista da viabilidade, quanto da qualidade dos resultados (ORTÚZAR; WILLUMSEN, 2006). Além disso, métodos simplificados têm demonstrado resultados com baixa amplitude de erros, principalmente para aplicações em cidades menores (ANDERSON; OLANDER, 2002). Por fim, a abordagem principal das ferramentas para esse tipo de planejamento deve se basear nos preceitos de orientação à tomada de decisões, 
propondo alternativas convincentes de intervenção, o que mais uma vez justifica sua desejada simplicidade.

\subsection{Objetivos}

Este trabalho tem como principal objetivo a construção de uma base referencial para o uso, adaptação e desenvolvimento de ferramentas computacionais voltados à prática do planejamento urbano, cujas condições favoreçam aplicações principalmente em cidades médias de países em desenvolvimento. Propõe-se, nesse sentido, a caracterização de um modelo sequencial para a previsão da demanda por transporte urbano, com foco nas viagens realizadas por transporte público e baseado nas necessidades de planejamento particulares desses países. Pretende-se, neste modelo, utilizar dados de fácil obtenção, executando procedimentos simples que, baseando-se em hipóteses realistas, possam gerar resultados de fácil interpretação. Busca-se, através de uma aplicação prática do modelo, analisar as ferramentas e procedimentos utilizados, explorando os resultados tanto do ponto de vista da aplicação, quanto do ponto de vista operacional dos programas e ferramentas. Procura-se levantar argumentos que contribuam com a consolidação do modelo, tornando-o acessível e atrativo aos investimentos públicos e incentivando o planejamento urbano.

\subsection{Estrutura do trabalho}

O trabalho inicia-se com uma revisão acerca dos principais temas envolvendo a prática do planejamento urbano, onde são apresentadas algumas técnicas de planejamento em transportes, suas funcionalidades e principais aplicações, conteúdo do capítulo 2. No capítulo 3 são apresentados os recursos disponíveis na cidade de São Carlos para utilização no processo de planejamento urbano, definindo uma metodologia que se adéque às características de cidades de países em desenvolvimento. No capítulo 4 é aplicada esta metodologia para estimar o uso do solo e a demanda por viagens na cidade de São Carlos, fornecendo uma base para análise das ferramentas e procedimentos utilizados. No capítulo 5 é feita uma análise de todas as ferramentas utilizadas nessa aplicação, sob distintos pontos de vista operacionais e aspectos de viabilidade e incentivo para o processo de 
planejamento. No capítulo 6 são apresentadas as conclusões e algumas sugestões para trabalhos futuros, encerrando-se o trabalho com a lista de referências bibliográficas utilizadas. 


\section{Capítulo 2 - Revisão bibliográfica}

É apresentada neste capítulo uma breve revisão dos temas envolvidos no presente estudo, conforme a literatura pesquisada. Essas informações têm o papel de contextualizar a prática do planejamento urbano nos países em desenvolvimento, expondo suas principais dificuldades e técnicas. São apresentados métodos e modelos de planejamento urbano em transportes, servindo de base para a escolha de uma metodologia adequada às características de uma cidade média localizada em um país em desenvolvimento, tema do capítulo 3, e sua aplicação na cidade de São Carlos, tema do capítulo 4. São ainda abordados os recursos computacionais normalmente disponíveis nesses países, fornecendo argumentos para a análise das ferramentas selecionadas, tema do capítulo 5 .

\subsection{O processo de urbanização e o crescimento das cidades}

A estrutura urbana tão comum nos dias de hoje é resultado de um longo e contínuo processo que envolve diversos fatores políticos e socioeconômicos. Através da literatura pesquisada, procura-se caracterizar o cenário urbano, explorando suas principais variáveis no sentido de possibilitar uma melhor compreensão de suas complexas relações.

\subsubsection{A história da urbanização}

Com os avanços tecnológicos cada vez mais presentes na Europa do século XVIII, começaram a surgir engenhosidades com as mais variadas funções, onde o princípio geral era transformar e otimizar as diferentes formas de energia para produzir determinados efeitos. O estudo dessas possibilidades começou a despertar o conceito de que tais mecanismos tornavam mais viáveis diversas atividades cotidianas. Através de efeitos que substituíam grande quantidade do trabalho humano normalmente dispendido, notaram-se que havia inúmeras formas de tirar proveito das então chamadas máquinas. Passaram-se então a mecanizar as atividades de produção agrícola e trabalhos artesanais, aumentando a eficiência produtiva e tornando os produtos finais mais viáveis economicamente. 
Dessa forma, teve início a chamada Revolução Industrial (HOBSBAWM, 2003), quando toda a cadeia produtiva foi remodelada sob o princípio da produção em grande escala proporcionada pelo advento das grandes máquinas. Tal princípio se baseava na constatação de que as pessoas, ou consumidores, possuíam necessidades semelhantes e que, através da industrialização, essas necessidades poderiam ser atendidas de forma mais rápida, barata e lucrativa. Entretanto, sabia-se que esse novo sistema significava a presença de novas necessidades acrescidas ao processo de produção. Entre elas, a concentração de recursos e mão-de-obra, além de meios que permitissem tais concentrações, como as infraestruturas de transporte e aglomeração, tanto dos recursos, quanto da mão-deobra necessária.

Essa necessidade de aglomeração provocou o surgimento de grandes complexos industriais, fazendo com que muitos trabalhadores passassem a residir junto aos locais de trabalho, desde, inclusive, a própria construção dos complexos até o consequente trabalho nas atividades de produção das indústrias. Assim, os donos dessas indústrias promoveram o desenvolvimento não só dos recursos tecnológicos envolvidos, mas também de uma nova estrutura de cidade condensada e organizada, num processo que mais tarde seria chamado de urbanização.

Esse processo aumentou a importância das cidades a partir da formação de polos de grande concentração de pessoas e capital, criando novas possibilidades e estilos de vida (JENKS et al., 2000). A partir de então, a urbanização foi se tornando mais abrangente e acelerada, proporcionando a migração de famílias de diversas regiões para os grandes polos urbanos, em busca de novas oportunidades. Essa migração, ao longo dos anos, ocasionou a estagnação ou até o decréscimo das populações rurais, quando, por outro lado, as populações urbanas aumentaram surpreendentemente.

Já nos países em desenvolvimento, como ilustrado por Raia Júnior (1995), o processo de urbanização, apesar de semelhante, apresentou algumas importantes diferenças. A principal delas é que nesses países a industrialização só teve início bem mais tarde e ocorreu de forma mais lenta e desestruturada. Ao mesmo tempo, os grandes produtores agrícolas, utilizando máquinas e técnicas importadas dos países desenvolvidos, aumentavam sua produtividade dispensando trabalhadores rurais, além de baratear os produtos agrícolas, tornando-os mais atrativos e eliminando a concorrência de pequenos produtores. Esses fatores fizeram com que 
houvesse uma oferta de trabalhadores urbanos migrantes muito maior do que a quantidade demandada pelas indústrias, gerando populações urbanas excessivas, incapazes de serem adequadamente acomodadas.

Diante de tais circunstâncias, muitos trabalhadores que chegavam à procura de melhores condições de vida se viam obrigados a enfrentar condições precárias de subsistência. Esse grupo de pessoas passou a formar as chamadas classes baixas, que alimentavam o crescente sistema capitalista através da desigualdade social. Essas pessoas não viam outra opção senão aceitar a exploração imposta pelo novo sistema, que oferecia baixos salários, condições exaustivas de trabalho e habitações improvisadas, criando cidades cheias de problemas, mas que também promoviam a fortuna das classes altas.

Entretanto, segundo Jenks et al. (2000), mesmo com diversos problemas provenientes de processos de urbanização precipitados e sem planejamento, a vida urbana oferece oportunidades que não seriam possíveis nos ambientes rurais, onde muitas vezes as condições de vida acabam sendo economicamente insustentáveis. Esse aspecto se tornou mais evidente quando os trabalhadores se deram conta de que, apesar de individualmente não tivessem grande importância para o sistema, juntos formavam um dos principais recursos capazes de mantê-lo. $E$ isso fez com que a massa trabalhadora se organizasse e se mobilizasse em busca de melhores condições, conquistando aumentos salariais, reduções da carga horária de trabalho, entre outros benefícios. Com esses avanços, muitos integrantes das classes baixas melhoravam suas condições de vida, passando a fazer parte das classes médias, junto com as quais as cidades também melhoravam suas condições de desenvolvimento. Nas classes baixas permaneciam em sua maioria os desempregados e algumas classes trabalhadoras mais desfavorecidas.

\subsubsection{A urbanização atual}

Com o passar dos anos, o processo de urbanização foi se tornando cada vez mais abrangente e acelerado, dando origem a inúmeras cidades e polos urbanos. As primeiras grandes cidades se tornaram polos de gigantescas concentrações populacionais, formando as chamadas metrópoles, cuja importância cresceu a níveis mundiais. Essas cidades atraíram um número tão elevado de pessoas, que em muitos casos suas cidades vizinhas, por influência de tal proximidade, apresentaram 
altos índices de crescimento, o que passou a provocar o fenômeno das regiões metropolitanas, ou regiões urbanas homogêneas (MANZATO, 2007). Com isso, algumas cidades tiveram suas zonas rurais praticamente extintas, convertidas em zonas urbanas, tamanho o crescimento populacional ocorrido.

Hoje, o cenário urbano começa a viver uma nova fase, onde algumas cidades tendem a estabilizar suas populações, seja pela saturação do solo disponível para ocupação, do limite de capacidade das infraestruturas urbanas, ou mesmo pela estabilização das taxas de migração e natalidade com as taxas de imigração e mortalidade. De qualquer forma, o processo de urbanização está intimamente ligado às condições de tecnologia, ciência e informação às quais as cidades estão submetidas (SANTOS, 2008). Do mesmo modo, conforme também apontado por Santos (2008), as configurações urbanas e rurais de uso do solo sofrem grande influência dos meios de transporte e telecomunicações. Isso também ocorre em âmbito global, onde os avanços tecnológicos, assim como a disseminação da informação, influenciam tanto os processos de crescimento, quanto a qualidade do desenvolvimento urbano. Porém, mesmo com tantos avanços, a falta de organização e planejamento tem sido uma das principais causas dos diversos problemas incidentes no ambiente urbano, em especial nos países em desenvolvimento. Dentre os problemas mais visíveis, pode-se citar a violência, a poluição, os grandes congestionamentos, filas e atrasos das mais diversas naturezas, além dos assentamentos irregulares e precários, como cortiços e favelas.

Um problema bastante característico nas cidades brasileiras, conforme abordado por Raia Júnior (1995), é o processo de especulação urbana, onde são loteadas áreas afastadas da malha urbana, valorizando terras de localização intermediária que passam a contar com melhores infraestruturas. Conforme Lima (1998), esse processo traz diversas consequências negativas para a população em geral e, principalmente, para a população de baixa renda. Esta última, além de sofrer com o aumento dos impostos para o custeio das obras de infraestrutura, vê como única opção estabelecer moradia nas regiões periféricas, sofrendo os efeitos da distância em relação aos locais de emprego e equipamentos públicos. Maiores distâncias aumentam o tempo e custo de transporte, em detrimento de outras necessidades.

Outro problema semelhante é o advento dos condomínios fechados, normalmente construídos para a população de alta renda, mas que também podem 
ser motivo de especulação imobiliária. Além disso, costumam criar "buracos" na configuração urbana, com infraestruturas exclusivas e prejudicando o atendimento das regiões vizinhas. Nesse ponto, é importante notar como as descontinuidades e vazios urbanos provocados por esses artifícios prejudicam, entre outras coisas, a acessibilidade (LIMA, 1998), mobilidade e o transporte urbano, em especial o transporte público. Também se pode dizer que nos países em desenvolvimento costuma ser maior a desigualdade social, o que, diante das diferentes necessidades da população, provoca um desequilíbrio na estrutura de serviços públicos como o sistema de transporte. Percebe-se, portanto, que o processo de urbanização e o sistema de transporte de uma cidade exercem influência direta um sobre o outro, evidenciando a necessidade de estudos urbanos que levem em conta essa relação.

Os países em desenvolvimento vêm de uma situação de dependência dos transportes não motorizados (caminhada, bicicleta, tração animal) e do transporte público (VASCONCELLOS, 2000). Porém, com a popularização do automóvel, as estruturas urbanas se mostram cada vez mais inaptas a suportar o número crescente de veículos, provocando um processo equivocado e desorganizado de adaptação que, além de não resolver o problema dos automóveis, acaba prejudicando o uso dos outros modos. Conforme apontado por Schrank (2004), pequenas e médias cidades são vulneráveis ao aumento do congestionamento devido à inabilidade de seus sistemas de transporte para acomodar o crescimento acelerado.

Ao mesmo tempo, as cidades médias vêm apresentando expressivos crescimentos populacionais, tornando-as a classe de maior representatividade em termos gerais de população (RAIA JúNIOR, 1995). Além disso, conforme Santos (2008), as cidades médias passaram a concentrar populações de classes médias, mais uniformes, e também com tendências mais intelectualizadas, promovendo sua importância econômica no cenário nacional e até mundial. Diante de tais considerações, fica evidente a abrangência cada vez maior dos problemas urbanos atuais, em especial os problemas relacionados ao transporte nas cidades médias, refletindo a necessidade de estratégias de ação globais. Essa iniciativa compreende desde estudos e trabalhos mais direcionados, até políticas de planejamento e desenvolvimento urbano que possam ser colocadas em prática através de adequado incentivo. 


\subsection{O planejamento urbano e suas principais vertentes}

No sentido de conceituar o processo de planejamento, Lopes (1998) cita algumas de suas abordagens clássicas, entre as quais se podem destacar: Análise Política - objetivos e metas definidos a partir de métodos científicos como engenharia, economia, estatística e matemática, permitindo um processo racional de decisão; Aprendizado Social - objetivos e metas definidos continuamente a partir da experiência prática confrontada com o conhecimento teórico; Reforma Social objetivos e metas definidos pelo estado, num processo de planejamento institucionalizado. Cada uma dessas abordagens apresenta instrumentos valiosos no que se poderia chamar de processo ideal de planejamento urbano, considerando as dificuldades que se impõem na realização desse processo, principalmente nas cidades dos países em desenvolvimento.

Ainda se tratando de conceituação, atenta-se para a distinção de significado do termo "planejamento estratégico", comumente utilizado para definir o processo de planejamento de forma abrangente, integrada e aplicada, mas também usado para descrever um instrumento específico de intervenção urbana, que será discutido no item 2.2.2.

\subsubsection{O processo de planejamento urbano}

De acordo com Ultramari e Rezende (2008), a evolução do processo de planejamento urbano no Brasil ao longo dos anos tem mostrado os seguintes aspectos: problemas urbanos de mesma natureza, porém maior complexidade; maior capacitação científica e tecnológica disponível; diminuição dos recursos públicos do setor, como quadro de funcionários e recursos financeiros, incentivando o aumento da participação privada no processo; aumento da participação da comunidade, porém ainda de forma mais expressiva devida à sua obrigatoriedade do que ao real interesse da população. De maneira geral, a relação que se estabelece entre esses aspectos pode ser justificada pelo fato de que, com o passar dos anos, a sociedade se expande e desenvolve novos conhecimentos, tecnologias, necessidades, leis e costumes, tornando-se cada vez mais abrangente e complexa. Apesar de tal complexidade, esse desenvolvimento promove melhores condições de planejamento que, por sua vez, promovem melhores condições de desenvolvimento. 
Um fator favorável para o planejamento urbano atual é a possibilidade de analisar as políticas urbanas passadas e suas presentes consequências, visto que são necessários longos períodos de tempo para que se possam gerar mudanças significativas no cenário urbano. Talvez esse seja o maior obstáculo para um efetivo processo de planejamento, já que os períodos dos mandatos políticos são inferiores ao tempo necessário para promover tais mudanças. Além disso, a escassez de recursos, sempre tão disputados, e as limitações provenientes da cultura geral apresentam obstáculos adicionais. Por isso é importante a definição de políticas e métodos científicos sólidos que se mantenham focados em seus objetivos, mesmo tendo eventualmente alterados seus agentes e recursos envolvidos.

Apesar das dificuldades, é importante notar o ganho de qualidade que se tem ao passar de uma situação de políticas simplesmente paliativas para uma situação onde é de fato incentivado o processo de planejamento, assumido com seriedade e responsabilidade. Segundo Lopes (1998), independentemente dos objetivos específicos dentro do processo de planejamento estratégico urbano, o próprio processo em si representa uma importante ação no sentido de promover melhores condições de vida nas cidades. Isso se deve ao fato do processo de planejamento promover o levantamento, organização, processamento e análise de informações acerca das cidades, sugerindo e orientando diversas formas de atuação. De maneira semelhante acrescentam Ultramari e Rezende (2008) que a realização do processo de planejamento tem importante papel no aprendizado da participação popular, da compreensão técnica da realidade e da comunicação entre agentes com interesses diversos.

\subsubsection{O Plano Diretor e o Planejamento Estratégico}

Diante da importância do processo de planejamento urbano e das dificuldades presentes para a sua prática no Brasil, assim como no contexto dos países em desenvolvimento, alguns esforços tem sido feitos no sentido de incentivar e promover essas atividades de planejamento. Numa tentativa de regular o processo de desenvolvimento das cidades brasileiras, o Governo Federal, através do Estatuto das Cidades (BRASIL, 2001), fornece um valioso recurso, regulamentando a elaboração pelas cidades de Planos Diretores de Desenvolvimento Urbano. De acordo com a lei, o Plano configura o instrumento básico da política de 
desenvolvimento e expansão urbana, fazendo-se obrigatório para cidades com mais de 20 mil habitantes, dentre outras classificações.

Outro instrumento igualmente importante que, entretanto, não possui apelo legal são os Planejamentos Estratégicos Municipais que, segundo Ultramari e Rezende (2008), configuram um mecanismo de gestão municipal inovadora. Fundamentado nos princípios da administração moderna, normalmente inseridos no cenário privado, o Planejamento Estratégico apresenta uma abordagem diferente em relação ao Plano Diretor. Através das considerações feitas por Ultramari e Rezende (2008) acerca dos dois instrumentos de planejamento urbano, pôde-se construir a Tabela 2.1, ilustrando suas principais diferenças.

Tabela 2.1 - Principais diferenças entre Plano Diretor e Planejamento Estratégico.

\begin{tabular}{lcc}
\hline Atributo & Plano Diretor & Planejamento Estratégico \\
\hline Incentivo: & Legislação & Interesses diversos \\
\hline Objetivo: & Regulador político/social & Eficiência socioeconômica \\
\hline Aplicação: & Generalizada & Caso a caso \\
\hline Abordagem: & Aspectos básicos & Multidisciplinar \\
\hline Período: & Longo prazo & Médio a longo prazo \\
\hline
\end{tabular}

Considerando as afirmações de Lopes (1998), tem-se que a estrutura básica do planejamento urbano deve reunir a participação público/privada, a visão de futuro e o foco na ação. Esse argumento, levada em conta sua abrangência no contexto político estabelecido por ambos os instrumentos de planejamento aqui descritos, oferece maior relação de conformidade com as políticas desempenhadas na prática do Planejamento Estratégico. Todavia, dada a obrigatoriedade legal desempenhada pelo Plano Diretor, é comum ainda que este se mostre mais expressivo no sentido de promover a estrutura básica de planejamento urbano na grande maioria das cidades.

Nesse ponto, entende-se que os dois instrumentos possuem características vantajosas, sugerindo sua complementaridade de forma que, se utilizados em conjunto, oferecem uma excelente estrutura para o processo de planejamento 
urbano. E conforme ainda levantado por Ultramari e Rezende (2008), para promover a qualidade dos Planos Diretores e Estratégicos, destaca-se a exigência de continuidade, fiscalização e reavaliações. Dessa forma, acredita-se que com esses e outros recursos, os obstáculos do planejamento urbano antes destacados podem ser minimizados e superados, aprimorando o processo de desenvolvimento das cidades brasileiras e dos demais países em desenvolvimento.

\subsection{Técnicas de planejamento urbano e de transportes}

Com o intuito de auxiliar a prática do planejamento urbano e de transportes, foram aqui reunidas importantes técnicas entre métodos, modelos, abordagens e mecanismos, organizados de acordo com sua natureza e características de aplicação.

\subsubsection{Pesquisa Origem/Destino}

A Pesquisa Origem/Destino, ou Pesquisa O/D, é um sistema de obtenção de informações, normalmente realizada em forma de entrevistas pessoais, onde se questionam as informações referentes às viagens realizadas pelos entrevistados em um dia típico. Contém as origens, motivos, horários, modos de transporte utilizados, tempo gasto e finalmente os destinos, podendo-se ter mais ou menos informações dependendo dos objetivos e recursos associados à pesquisa. Esse método tem como vantagem o levantamento dos dados das viagens o mais próximo possível da realidade, podendo definir apenas os pontos de início e término das viagens ou também pontos intermediários e, em alguns casos, até mesmo a trajetória completa, embora para isso sejam normalmente necessários métodos auxiliares. No entanto, o método não é capaz de prever as viagens futuras, sendo também para isso necessários métodos auxiliares.

As entrevistas podem ser realizadas em domicílios estrategicamente distribuídos, onde é comum realizar junto à pesquisa de viagens uma pesquisa socioeconômica, cujos dados muitas vezes estabelecem padrões que se relacionam com as características das viagens realizadas, possibilitando a previsão do fluxo de viagens com base nesses fatores. Em alguns casos, a pesquisa é realizada em trechos pré-definidos, onde as entrevistas, normalmente mais simplificadas, podem ser feitas no interior do próprio veículo ou terminal, podendo conter inclusive 
perguntas sobre a qualidade da viagem. Nesse tipo de pesquisa por trechos, é comum ainda simplificar o processo por meio de contagens, utilizando bilhetes, contagem visual ou equipamentos ITS (Intelligent Transportation System), fornecendo então informações não mais individuais, porém obtendo o fluxo de viagens no trecho analisado com razoável precisão.

Como desvantagem, pode ser citada a necessidade de investimentos consideráveis, seja com mão-de-obra ou com equipamentos, e deve-se ter em vista que, para que os resultados representem a realidade, é preciso observar uma parcela mínima em relação ao total projetado. Para maiores detalhes sobre os diferentes tipos de pesquisa, ver Ortúzar e Willumsen (2006), e Ferraz e Torres (2004).

\subsubsection{Modelos sequenciais de demanda (quatro etapas)}

O meio mais utilizado para prever o fluxo de viagens atual e futuro numa determinada região de estudo é dividir o "problema" da viagem em quatro passos, ou etapas. Esse procedimento é comumente chamado de modelo convencional de demanda ou modelo de quatro etapas (EOM, 2007) e é dividido em: geração de viagens, distribuição de viagens, escolha modal e alocação do tráfego. O modelo estima os fluxos de viagem com base nas características de comportamento dos usuários do sistema de transportes. Esse comportamento é definido a partir de informações e considerações acerca do conjunto de indivíduos presentes nos locais definidos, na tentativa de suprir da melhor forma possível suas necessidades referentes ao transporte.

As principais vantagens dessa abordagem são as diferentes formas possíveis de cumprir cada passo, incluindo meios que não exijam informações complexas e precisas, o que a torna uma opção muito atrativa. Outra característica interessante é a possibilidade de utilizar as diversas partes de um modelo desenvolvido para uma região em outras regiões com características semelhantes, sem a necessidade de muitos ajustes. Essa capacidade de transferência foi abordada por Agyemang-Duah e Hall (1997) e por Mohammadian e Zhang (2007), mostrando resultados promissores. Em contrapartida, esse tipo de análise tem seus resultados normalmente baseados em hipóteses simplificadoras. Isso acaba por gerar resultados menos precisos, o que requer muitas vezes um processo de calibração 
ou validação estatística. A seguir, descrevem-se os quatro passos desse modelo e suas principais características.

\subsubsection{Primeiro passo: geração de viagens}

O primeiro passo considera os motivos que levam os indivíduos a realizar viagens e é dividido em duas partes: produção de viagens, em geral associadas às origens, e atração de viagens, em geral associadas aos destinos. As viagens produzidas podem ser estimadas considerando o comportamento individual ou assumindo que um determinado conjunto de indivíduos possui o mesmo comportamento quanto ao desejo por viagens, atribuindo essa produção a uma área pré-definida, denominada zona de tráfego, com base no número de pessoas pertencentes a ela. As viagens atraídas são associadas a polos de atração de viagens como empresas, escolas, indústrias, hospitais, entre outros, podendo-se ou não considerar a capacidade de atendimento desses locais, de acordo com a precisão exigida pelo modelo.

\subsubsection{Segundo passo: distribuição de viagens}

O segundo passo consiste em definir cada viagem ou conjunto de viagens, associando suas origens a seus destinos, normalmente atribuindo um número de viagens para cada zona de tráfego, como definido no primeiro passo. Como resultado, tem-se uma matriz $n$ por $n$, onde $n$ representa o número de zonas de tráfego analisadas. Essa matriz é chamada de matriz Origem/Destino, ou matriz O/D, e contém o número de viagens entre cada par de zonas, além das viagens internas de cada zona, ou seja, as viagens com origem e destino na mesma zona. O modelo mais comumente usado para o cálculo da matriz O/D é o chamado modelo gravitacional, analogamente à lei de atração de massas (ORTÚZAR; WILLUMSEN, 2006). Esse modelo possui algumas possíveis variações, mas é basicamente constituído de uma equação que define o número de viagens entre cada par de zonas, proporcionalmente ao número de viagens produzidas e atraídas em cada zona em relação ao total de viagens em todas as zonas. Considera-se também o custo (distância, tempo ou um conjunto de variáveis) entre as zonas, além de alguns fatores de ajuste que variam de acordo com a região analisada. 


\subsubsection{Terceiro passo: escolha modal}

Nesse passo, calculam-se as probabilidades dos indivíduos escolherem realizar suas viagens utilizando os diferentes modos de transporte disponíveis, como automóvel, transporte coletivo, bicicleta, caminhada, entre outros. Para isso, consideram-se as diferentes características de cada modo de acordo com a necessidade de seus usuários, como por exemplo, o tempo de viagem, o custo, o conforto e a segurança, entre outros fatores. São então definidas funções de utilidade para cada modo com base em tais características e a partir das informações socioeconômicas são determinadas as escolhas de cada tipo de usuário. A partir da escolha modal podem ser geradas submatrizes O/D com 0 número de viagens para cada modo considerado.

\subsubsection{Quarto passo: alocação de tráfego}

No último passo, as viagens definidas nas matrizes O/D são então associadas às suas respectivas rotas, com base em uma rede viária contendo todas as possíveis vias por onde os veículos podem trafegar ao realizar as viagens. Normalmente, para cada modo de transporte considera-se uma rede viária diferente, já que cada modo exige uma estrutura viária particular. Para esse procedimento, conforme Eom (2007), dois métodos principais podem ser citados: o método do "tudo ou nada", com suas variações, e o método de alocação estocástica.

O "tudo ou nada" considera que as viagens serão feitas pela melhor rota possível, o que pode significar a rota de menor distância ou de menor tempo, no caso de vias com diferentes velocidades de tráfego. No entanto, não são consideradas as capacidades das vias, permitindo que todas as viagens sejam feitas pelas melhores rotas, o que normalmente não representa uma situação realista, porém oferece resultados de fácil compreensão. Nas suas variações, podem-se considerar as capacidades das vias, fazendo com que vias mais congestionadas passem a ter tráfegos mais lentos, tornando outras rotas mais atrativas e assim, através de um processo iterativo, distribui-se todo o tráfego. Já no método de alocação estocástica, consideram-se outros fatores para calcular a probabilidade de escolha entre as rotas, já que as pessoas possuem percepções diferentes e portanto nem sempre escolhem as rotas mais curtas ou mais rápidas. 
Independentemente do método utilizado, gera-se enfim o fluxo de viagens em cada via. Pode-se dessa forma quantificar a demanda por transporte na região analisada e verificar os impactos nessa demanda provocados por fatores externos como a reestruturação da rede viária ou o crescimento populacional, contanto que sejam executados os quatro passos mencionados utilizando os dados anteriores e posteriores às mudanças a serem avaliadas.

\subsubsection{Outros modelos e métodos}

De acordo com os dados e ferramentas que se têm à disposição e considerando os diferentes objetivos de cada estudo, pode-se tornar favorável a utilização de métodos auxiliares, seja cumprindo etapas pertencentes aos modelos já citados, ou mesmo substituindo determinados procedimentos. Em alguns casos pode-se até mesmo utilizar outras abordagens, criando modelos com base em outros tipos de dados e considerações.

\subsubsection{Métodos baseados em fatores de crescimento}

Alguns métodos para estimar as demandas futuras baseiam-se nos dados atuais modificados por fatores de crescimento definidos para as zonas ou setores em questão. Como as viagens possuem origens e destinos, é comum ter dois fatores de crescimento associados a uma única viagem, permitindo diferentes soluções, como encontrar a média entre os dois fatores ou estabelecer uma proporção de significância através de processos iterativos. Entretanto, a utilização de fatores de crescimento é bem mais limitada no caso de ocupações em novas zonas (ORTÚZAR; WILLUMSEN, 2006), já que um crescimento que parte de valores próximos de zero não permite um cálculo razoável de um fator de crescimento percentual.

\subsubsection{Métodos entrópicos}

$\mathrm{Na}$ ausência de informações que caracterizem o ambiente analisado, é possível se utilizar de métodos que distribuem as viagens maximizando a entropia, numa analogia com o comportamento dos gases (KAWAMOTO, 2004). Dessa forma, consideram-se as associações de viagens mais prováveis com base num conjunto 
de resultados possíveis. Essa alternativa pode servir, por exemplo, para simular ambientes uniformes, quando a infraestrutura urbana propicia volumes de viagem bem distribuídos.

\subsubsection{Modelos baseados em atividades}

Outra abordagem para estimar os volumes de viagem, que considera fatores diversos em relação às abordagens convencionais, consiste em considerar padrões de comportamento de famílias com diferentes características e que definem suas viagens diárias com base nas suas participações em atividades (EOM, 2007). O método leva em conta fatores como necessidades biológicas, atividades interpessoais, horários de abertura e fechamento dos locais de destino e a sequência de atividades ao longo do dia. Esses modelos possuem uma maior complexidade, porém oferecem uma boa alternativa para analisar o impacto de mudanças pontuais como a inauguração de um novo polo de atração de viagens ou a mudança dos horários de funcionamento de polos já existentes.

\subsubsection{Cenários de desenvolvimento}

Um importante recurso para o processo de planejamento é a divisão de diferentes hipóteses em cenários distintos de desenvolvimento, detectando possibilidades ou definindo alternativas. O termo cenário é usado para descrever diferentes tipos de estudos orientados ao futuro, como análises de tendências, prognósticos, previsões, análises de variação, análise de sensibilidade, entre outros (TRESS; TRESS, 2003). Dessa forma, independentemente dos métodos e objetivos do planejamento a ser realizado, é comum partir-se de um cenário inicial, representando as condições atuais, confrontando-o com cenários futuros gerados a partir de determinadas características.

De acordo com a abordagem utilizada, os cenários podem ser criados com base em diferentes formas de classificação. Segundo Harms (1995), os cenários podem ser divididos em "cenários de projeção", gerados a partir das tendências e expectativas atuais, e "cenários de contraste", gerados a partir das possíveis alternativas de desenvolvimento. Outra classificação é sugerida por Emmelin (1995), dividindo os cenários em "tendência natural", "resultado de políticas", "futuro desejado" e "futuro inesperado". Essas classificações podem auxiliar a organização 
dos dados e hipóteses iniciais, definindo quais características melhor representam cada tipo de cenário.

Através dos cenários de desenvolvimento, torna-se mais fácil e produtivo trabalhar com hipóteses, além do que a criação de cenários incentiva o pensamento crítico sobre os riscos e as inter-relações inerentes dos sistemas representados (WOLLENBERG et al., 2000). Nesse sentido, a utilização de cenários se mostra um recurso fundamental no suporte ao processo de planejamento e à tomada de decisões.

\subsubsection{Uso do solo e transportes}

Os planejadores reconheceram há tempos a relação entre os padrões de uso do solo e a demanda por transporte (HARRIS, 1985). Diferentes estudos já foram realizados explorando as diversas formas de influência tanto do uso do solo sobre o transporte, quanto do transporte sobre o uso do solo. Apesar disso, alguns autores defendem que a influência do uso do solo não é tão significativa para a demanda por transporte se comparada com aquela provocada por fatores socioeconômicos (EWING et al., 1996). De qualquer forma, uma influência ainda mais direta nesse sentido é que o uso do solo certamente define os motivos das viagens, muito mais do que a quantidade delas. Áreas industriais, por exemplo, atraem principalmente viagens de ida ao trabalho, sendo que áreas comerciais podem atrair viagens tanto de ida ao trabalho, quanto de ida às compras.

Em estudo realizado por Hensher et al. (2004), demonstra-se que as principais variáveis que influenciam a geração de viagens são: uso do solo, população e emprego. Ao observar a relação que os diferentes usos do solo, através de sua configuração de ocupação, estabelecem sobre a localização geográfica das variáveis população e emprego, pode-se dizer que as características de ocupação e uso do solo se mostram um ótimo ponto de partida para os estudos de planejamento de transportes urbanos.

De acordo com Schrank (2004), as principais razões que justificam o uso de informações socioeconômicas e de uso do solo no processo de planejamento é que elas são de fácil obtenção, compreensão e análise. Desse modo, essas informações representam ótimos recursos para o planejamento urbano em países em desenvolvimento. Nesse sentido, é interessante considerar diferentes abordagens 
que utilizam modelos e métodos que complementam o uso de informações socioeconômicas e de uso do solo, apresentando resultados mais abrangentes e menos suscetíveis a erros.

\subsubsection{Os recursos computacionais}

Com os avanços tecnológicos cada vez mais acelerados, é constante o aparecimento de novas técnicas e recursos servindo de base para diferentes objetivos e abordagens no processo de planejamento. Muitas dessas novidades somente se mostram viáveis para utilização prática quando um conjunto de requisitos é atendido. Nesse contexto, observa-se que as técnicas de planejamento atuais estão frequentemente atreladas a recursos computacionais cujas funções variam de acordo com as características de cada método.

Num primeiro momento, os computadores passaram a ser utilizados devido à sua grande capacidade de processamento, automatizando tarefas muitas vezes repetitivas e dispendiosas. Posteriormente, com a disseminação do uso computacional, novas funções foram sendo desenvolvidas e exploradas, trazendo inúmeras possibilidades para o processo de planejamento. Com o desenvolvimento das interfaces gráficas tornou-se possível o tratamento de informações geográficas de forma mais abrangente, trazendo, mais uma vez, novas possibilidades de aplicação. Nesse momento, surge uma importante ferramenta para o planejamento urbano: o Sistema de Informações Geográficas (SIG).

Explorado por diversos autores (SINGH, 1996; KHAN et al., 2007), o SIG tem incorporado cada vez mais funcionalidades e aplicações, desde o cadastramento e visualização das informações geográficas até o processamento de modelos específicos baseados em sua interface. No entanto, observa-se que muitos estudos e análises de comportamento urbano têm-se utilizado do SIG principalmente como ferramenta de organização, visualização e apresentação de resultados gerados através de outras ferramentas (CLARKE; GAYDOS, 1998; JOHNSTON; DE LA BARRA, 2000). Esse fato se deve, entre outros fatores, à necessidade de ferramentas mais específicas de acordo com as características dos métodos e modelos empregados, além do uso normalmente mais consolidado dessas demais ferramentas. 
Essa utilização conjunta de duas ou mais ferramentas representa um ponto delicado e importante do processo. É preciso atentar para a compatibilidade entre as ferramentas e a sequência de uso das mesmas. Esses fatores têm influência nos níveis de vinculação desejados, definindo importantes características operacionais dos modelos utilizados. Quanto maior o nível de vinculação, maior a dependência que cada ferramenta exerce sobre as demais. Essa dependência normalmente dificulta o processo de adaptação dos modelos quando há necessidade de se inserir novas informações, portanto é comum dar-se preferência para modelos de vinculação fraca, ou loose coupling (CLARKE; GAYDOS, 1998; KLOSTERMAN; XIE, 1997). Essa prática tem incentivado o uso do SIG como ferramenta complementar aos mais diversos tipos de modelos de planejamento.

Apesar disso, existe uma tendência de que as ferramentas baseadas em SIG possuam cada vez mais funcionalidades, incorporando métodos e diminuindo a necessidade da utilização de outras ferramentas complementares. Essa tendência pode ser observada na área de transportes com o crescente desenvolvimento dos Sistemas de Informação Geográfica para Transportes, ou SIG-T (KHAN et al., 2007). De qualquer forma, independente da utilização de modelos específicos, o SIG oferece recursos valiosos de cadastramento, organização e visualização de dados. Sua simples utilização, em muitos casos, torna possível a solução de diversos impasses relacionados à administração pública, no processo de tomada de decisões.

Além do SIG, muitos outros recursos computacionais têm sido utilizados no processo de planejamento urbano, como modelos específicos de simulação ou até mesmo jogos (ORTÚZAR; WILLUMSEN, 2006) e mundos virtuais (ORLAND et al., 2001). De forma geral, os recursos computacionais se mostram cada vez mais abrangentes e necessários, não ficando restritos a métodos e modelos já consolidados, mas representando um desenvolvimento contínuo e interdisciplinar para o processo de planejamento. Com o avanço e a disseminação do conhecimento computacional, os planejadores possuem maior contato com os programadores, o que facilita o desenvolvimento integrado de ferramentas e programas de acordo com as necessidades específicas e recursos disponíveis em cada situação. 
2.3.6.1 Ferramentas computacionais de planejamento urbano para países em desenvolvimento

O processo de planejamento urbano nos países em desenvolvimento apresenta uma série de obstáculos, entre fatores políticos, econômicos e culturais. Muitas cidades deixam de realizar estudos de planejamento ou realizam estudos ineficientes e incompletos, apenas para tentar diminuir seus problemas mais graves e imediatos. A constante falta de recursos tem se mostrado um fator decisivo para o desestímulo desses estudos. Recursos financeiros, humanos e tecnológicos, dada sua escassez, representam fatores que limitam a obtenção, organização e manipulação de dados e informações a respeito das cidades e suas infraestruturas.

Nesse sentido, observa-se a necessidade de meios mais acessíveis, do ponto de vista financeiro, tecnológico e operacional, que possibilitem que sejam colocados em prática estudos e atividades relevantes para o planejamento urbano. Na grande maioria das vezes, esses meios resumem-se em métodos e modelos adequados aos dados disponíveis e um conjunto de ferramentas que possibilite a execução desses procedimentos. Além disso, diante das diversas possíveis abordagens acerca das infraestruturas urbanas, diferentes modelos são necessários para cada tipo de estudo. Em consequência disso, tornam-se desejáveis ferramentas específicas para cada aplicação.

Dentre as ferramentas atualmente disponíveis no mercado, pouco esforço tem sido feito no sentido de desenvolver programas voltados para as características específicas dos países em desenvolvimento. Isso é até certo ponto compreensível, uma vez que, por motivos já mencionados, esses países muitas vezes deixam de lado o processo de planejamento, alocando recursos para outros fins considerados mais urgentes. Dessa forma, quando as cidades optam por realizar estudos de planejamento, é preciso adaptar as ferramentas disponíveis através do uso conjunto de ferramentas complementares e/ou através de artifícios, manipulando os dados de forma inteligente.

De acordo com Masser e Campbell (1991), existem três fatores principais que funcionam como requisitos para uma eficaz utilização de recursos computacionais no planejamento urbano nos países em desenvolvimento. São eles: uma estratégia de gerenciamento da informação baseada nas necessidades e recursos disponíveis, a consciência, engajamento e capacitação de todo o pessoal envolvido e, por fim, 
certa estabilidade do ponto de vista organizacional e administrativo. Mesmo com os contínuos avanços e as rápidas mudanças, características do ambiente computacional, esses fatores continuam representando de forma abrangente e relevante os principais obstáculos práticos para a escolha e implementação de ferramentas computacionais de planejamento nos países em desenvolvimento.

A escassez de recursos disponíveis representa um constante limitador das atividades de planejamento e, sob o ponto de vista computacional, restringe os investimentos tanto na aquisição, adaptação e desenvolvimento de ferramentas, quanto no treinamento necessário para utilizá-las. Outro problema, nesse aspecto, é a limitada capacidade de levantamento e principalmente de organização de dados e informações a respeito das características urbanas que influenciam o processo de planejamento. Por isso, é preferível reunir apenas a quantidade de informação mais relevante, aquela com a qual se possa trabalhar de forma contínua e organizada. Isso muitas vezes pode significar a substituição de levantamentos de dados reais por elaborações de hipóteses, ou evitar o uso de modelos que exigem calibração, para priorizar simulações que representem possíveis cenários. Essas estratégias refletem diretamente na escolha dos tipos de ferramentas que melhor atendem aos objetivos em questão.

A consciência, engajamento e capacitação do pessoal envolvido são características diretamente ligadas à estrutura e ao ambiente de trabalho, onde se deve incentivar a integração das informações e atividades relacionadas aos diferentes profissionais. São de grande importância a capacitação e a utilização da mesma base ferramental, unindo e centralizando os dados para que possam ser trabalhados de forma mais abrangente e integrada. Sempre que possível deve-se promover treinamentos e reuniões, difundindo as ferramentas, métodos e objetivos em vigor e avaliando o desempenho das atividades realizadas a fim de rever continuamente as estratégias adotadas.

A estabilidade organizacional e administrativa garante a continuidade do processo de planejamento, possibilitando a evolução e a sustentação do conhecimento empírico e eliminando a eventualidade de repetir os mesmos erros ou de considerar hipóteses excessivas. Essa continuidade também é importante no sentido de consolidar o uso das ferramentas escolhidas, formando uma base mais completa e confiável de dados e análises. 
Nesse contexto, o SIG é uma ferramenta que oferece mecanismos eficientes de organização e visualização dos dados, além de conter outros recursos e ferramentas para realização de análises. De forma geral, o SIG apresenta diversas funcionalidades de grande utilidade para o processo de planejamento urbano nos países em desenvolvimento e seu uso vem sendo aos poucos mais explorado nas cidades médias desses países. Essa ferramenta, mais especificamente quando voltada para o planejamento em transportes, o SIG-T, oferece suporte à grande maioria das necessidades das atividades de planejamento urbano comuns em países em desenvolvimento (KHAN et al., 2007).

Observa-se então a necessidade de estudos que não só documentem, como também investiguem o uso de ferramentas computacionais, tanto do ponto de vista técnico do planejamento urbano, quanto do ponto de vista operacional das ferramentas e programas. A partir de tais investigações criam-se argumentos para embasar a estrutura operacional das atividades de planejamento, reunindo e organizando os dados que se têm à disposição e utilizando modelos e métodos consolidados aliados a hipóteses realistas. 


\section{Capítulo 3 - Metodologia}

Neste capítulo são apresentados os principais recursos disponíveis na cidade de São Carlos para o processo de planejamento estratégico de uso do solo e transportes. Através dessas informações, determinam-se os procedimentos e métodos de planejamento que melhor se adaptam à realidade de uma cidade média localizada em um país em desenvolvimento. É proposta então a metodologia que serve como base para a aplicação apresentada no capítulo 4 , definindo as principais características e etapas do modelo adotado.

\subsection{Considerações iniciais}

Pretende-se, através da metodologia adequada, possibilitar a realização de uma aplicação que forneça informações passíveis de vários tipos de análises. Pode-se assim avaliar a aplicabilidade da metodologia no sentido de incentivar e auxiliar o processo de planejamento, tanto do ponto de vista da cidade estudada, quanto do ponto de vista operacional das ferramentas a serem empregadas. A fim de determinar qual metodologia melhor se adapta às necessidades de uma cidade média, nas condições particulares de um país em desenvolvimento, tem-se como base de estudo a cidade de São Carlos.

Localizada no interior do estado de São Paulo, a cidade de São Carlos é uma cidade de médio porte, com uma população que ultrapassa a faixa de 200 mil habitantes e se encontra em constante processo de crescimento. Seu sistema de transporte público é realizado atualmente por ônibus, com mais de 50 linhas principais, em sua grande maioria radiais/diametrais (ROCHA et al., 2007). Assim como em grande parte das cidades situadas em países em desenvolvimento, São Carlos também apresenta alguns obstáculos para a prática do planejamento urbano. Devido principalmente à falta de recursos no governo, à inviabilidade e conflito de interesses políticos e privados, assim como à cultura geral da população, o crescimento da cidade e sua respectiva infraestrutura dificilmente sofre alguma forma prática e integrada de controle. Esse fato pode ser claramente observado no sistema de transporte público da cidade, onde diversas linhas, denominadas especiais, foram sendo adicionadas de forma paliativa e sem o planejamento 
adequado, com o intuito de "acompanhar" o crescimento. O que ocorre é que um crescimento desordenado tem como consequência uma infraestrutura urbana desordenada que, por sua vez, tem como consequência um sistema de transporte público desordenado.

Uma característica interessante de São Carlos é o alto nível de capacitação técnica e tecnológica, em relação ao tamanho da cidade, que se deve principalmente às suas instalações de ensino e pesquisa. De forma geral, é mais fácil reunir, organizar e utilizar recursos para o estudo do planejamento no ambiente universitário. Além dos mecanismos de obtenção de dados, das ferramentas de pesquisa adquiridas e do conhecimento técnico para utilizar tanto as ferramentas quanto os dados, os estudos realizados nas universidades não comprometem o sistema urbano. Todos os testes, quando necessários, são realizados através de modelos e simulações e, apenas depois de confirmar sua funcionalidade e viabilidade, é que são colocados em prática. Porém, muitos estudos têm sido realizados e não aproveitados como poderiam, motivo pelo qual esse trabalho se preocupa em adequar a metodologia para futuras aplicações reais.

Através dos resultados almejados pretende-se possibilitar a análise do processo de ocupação urbana, além dos impactos sobre o sistema de transportes (mais especificamente, as diferenças nos volumes de tráfego) provocados pelo crescimento populacional da cidade em um determinado período de análise. Para que a metodologia pudesse ser então definida, foram reunidos dados e ferramentas disponíveis que pudessem contribuir com a proposta, de acordo com os modelos e métodos apresentados no capítulo 2.

\subsection{Dados disponíveis}

Todos os dados reunidos são provenientes de pesquisas e cadastramentos realizados por entidades públicas, de grande confiabilidade e de acesso relativamente fácil. Para sua utilização como parte de um modelo, os dados precisam ser previamente filtrados e trabalhados, porém, dentre as atividades relacionadas aos dados iniciais, não foi realizado nenhum levantamento em campo. Todas as informações já haviam sido cadastradas pelos respectivos órgãos responsáveis, exigindo apenas algumas consultas e solicitações para sua obtenção. 
São apresentadas a seguir as informações assim obtidas, de acordo com suas fontes.

\subsubsection{Plano Diretor de Desenvolvimento Urbano}

Como principal fonte de base para o planejamento urbano, São Carlos possui seu Plano Diretor, desenvolvido em 2002, onde constam diversos dados referentes às suas áreas rurais e urbanas (SÃO CARLOS, 2005). Esse documento, unido à observação das tendências de desenvolvimento da cidade, fornece informações fundamentais para a execução dos modelos de demanda por transporte. Dentre essas informações, pode-se destacar a classificação de uso do solo para os lotes ocupados da região urbana, dividindo-os em categorias de acordo com seus usos. Outra informação importante são as áreas que apresentam condições de ocupação urbana, definidas com base em fatores ambientais, tipo de solo, relevo, entre outros. E por fim, devem-se mencionar as informações que orientam o direcionamento da expansão urbana, definindo áreas mais desejáveis para futuras ocupações.

\subsubsection{Instituto Brasileiro de Geografia e Estatística (IBGE)}

Além do Plano Diretor, uma fonte imprescindível de informações são os levantamentos censitários do IBGE, realizados a cada 10 anos, que fornecem importantes informações populacionais estrategicamente divididas em zonas censitárias (IBGE, 2000). Essas zonas, com alguns possíveis ajustes, são comumente aproveitadas como Zonas de Análise de Tráfego. Para o estudo, foram utilizados os dados censitários do último levantamento, realizado em 2000. Complementando os levantamentos censitários, o IBGE também disponibiliza taxas de crescimento e estatísticas populacionais intermediárias ao período de 10 anos.

\subsubsection{Fundação Sistema Estadual de Análise de Dados (SEADE)}

Outra fonte importante a ser considerada são os dados disponibilizados pela fundação SEADE, onde podem ser encontradas diversas informações separadas por município, envolvendo desde fatores socioeconômicos até índices e indicadores (SEADE, 2009). Dentre essas informações, destacam-se os dados de vínculos empregatícios por setor de atividade, dada sua qualidade de quantificar as 
atividades de trabalho, um dos principais motivos de geração de viagens urbanas diariamente.

\subsubsection{Pesquisa Origem/Destino}

Um recurso igualmente útil para a aquisição de dados, porém ainda pouco explorado em termos de planejamento em cidades desse porte, é a Pesquisa O/D, que fornece além de informações socioeconômicas, um completo roteiro individual de viagens, considerando um dia típico. São Carlos teve uma Pesquisa O/D de boa representatividade realizada em 2007/2008 pelo Departamento de Transportes da Escola de Engenharia de São Carlos, STT - EESC - USP (RODRIGUES DA SILVA, 2008). Entre os dados mais relevantes para o estudo, pode-se citar a verificação dos motivos de viagem e dos modos de transporte utilizados, além da calibração de um fator que representa um padrão de distribuição de viagens entre as Zonas de Análise de Tráfego da cidade.

\subsubsection{Rede viária urbana}

Um recurso fundamental para o processo de planejamento de transportes da cidade é o cadastro de suas redes viárias urbanas. Esse cadastro, atualizado pelo Serviço Autônomo de Água e Esgoto (SAAE) de São Carlos em 1998, é largamente utilizado pelo Departamento de Transportes da Escola de Engenharia de São Carlos (STT - EESC - USP) em estudos de planejamento envolvendo a cidade. A rede principal, contendo todas as vias da região urbana, foi previamente trabalhada por Rocha et al. (2007), onde foram selecionadas apenas as vias pertencentes às inúmeras rotas utilizadas pelo sistema de transporte coletivo da cidade. Dessa forma, o estudo pode enfocar especificamente as viagens demandadas no sistema coletivo, proporcionando resultados mais realistas no que diz respeito a essa abordagem.

\subsubsection{Cadastro de loteamentos da cidade}

Durante o desenvolvimento do estudo, teve-se acesso a informações adicionais sobre condições mais atualizadas da cidade. Foi adquirido, junto à Prefeitura do Município, o cadastro de loteamentos da cidade, contendo inclusive os 
novos loteamentos a serem inaugurados, que no momento da consulta encontravam-se já aprovados ou em fase de aprovação (PREFEITURA MUNICIPAL DE SÃO CARLOS, 2010). A partir dessa informação, é possível avaliar as condições reais de desenvolvimento da cidade, à parte das diretrizes e expectativas apresentadas no Plano Diretor.

\subsection{Ferramentas computacionais disponíveis e suas funcionalidades}

Assim como os dados, as ferramentas reunidas foram exclusivamente aquelas que já se encontravam à disposição, não havendo nenhuma nova aquisição. O que houve, apenas, foi um processo de familiarização com os programas e ferramentas. Esse pequeno treinamento, assim como a própria disponibilidade dos programas, tirou grande vantagem dos recursos oferecidos pela universidade, no sentido de possibilitar e promover esse trabalho.

\subsubsection{SIG-T: TransCAD}

Um recurso muito utilizado em estudos de planejamento urbano, à disposição do Departamento de Transportes da Escola de Engenharia de São Carlos, é o programa TransCAD (http://www.caliper.com/tcovu.htm), que se trata de um conjunto de ferramentas para o Planejamento de Transportes num Sistema de Informações Geográficas. Dentre suas inúmeras ferramentas, o programa se mostra extremamente útil na tarefa de executar os principais procedimentos necessários para a execução de um modelo de demanda, particularmente um modelo baseado nos quatro passos mencionados no capítulo 2. Seu ambiente SIG permite a integração de todas as informações disponíveis, de forma que as hipóteses do modelo possam ser elaboradas com base nesses dados, possibilitando a execução de cada um dos passos através de ferramentas específicas. Para a etapa de geração de viagens, basta que se utilizem as informações georreferenciadas definidas para cada zona de tráfego. Para a distribuição de viagens, existe uma ferramenta que executa o modelo gravitacional. Para a alocação de tráfego, o programa oferece algumas opções, entre elas a ferramenta de alocação em rede pelo método do "tudo ou nada". 


\subsubsection{What if?}

Embora o TransCAD ofereça ferramentas perfeitamente capazes de lidar com os procedimentos do modelo de demanda aqui proposto, ele não possui meios igualmente práticos de estimar a expansão urbana com base nas taxas de crescimento obtidas a partir dos dados demográficos da cidade. Essa incapacidade se dá principalmente pelo fato de que o crescimento urbano esperado não está associado a um simples acréscimo da densidade populacional que mantém a mesma configuração atual de ocupação e uso do solo, mas sim de uma ocupação de áreas inicialmente vazias. Isso torna inviável a simulação do crescimento apenas pela multiplicação da população das zonas de tráfego por um coeficiente de variação.

Dessa forma, não seria possível prever a demanda futura, impossibilitando a análise dos impactos causados pelo crescimento da cidade, fato que pôde ser solucionado com a utilização de outro programa disponível para o estudo: o What if? (KLOSTERMAN, 2001; KLOSTERMAN, 2008; http://www.whatifinc.biz/). Diferentemente do TransCAD, o What if? não possui ferramentas capazes de prever fluxos de tráfego, porém oferece um conjunto de ferramentas que simulam cenários de crescimento urbano com base em diretrizes definidas a partir dos dados de ocupação e uso do solo para a região de estudo. Essa característica do programa possibilita que zonas de análise vazias possam acomodar novos loteamentos de acordo com as expectativas de crescimento provenientes do histórico de dados demográficos, simulando assim o crescimento da mancha urbana.

\subsubsection{TransCAD + What if?}

A utilização conjunta dos softwares TransCAD e What if? (RODRIGUES DA SILVA et al., 2009) permite, portanto, a previsão dos fluxos de tráfego atuais e futuros, possibilitando a análise dos impactos do crescimento urbano sobre a demanda por transporte, atendendo à proposta do estudo. Essa interação dos dois programas é possível graças ao fato de ambos permitirem o processamento de arquivos de formato comum: os shapefiles. A partir do método denominado por "fraca vinculação" (loose coupling), os resultados gerados em um dos dois programas são diretamente carregados no outro, permitindo a geração de novos 
resultados. Estes, por sua vez, podem ser reinseridos no primeiro para uma nova etapa de processamento (CLARKE; GAYDOS, 1998; KLOSTERMAN; XIE, 1997).

\subsubsection{Planilhas eletrônicas}

Uma ferramenta sempre presente, que também deve ser mencionada, são as planilhas eletrônicas, que possibilitam o livre manuseio dos dados, preparando-os para sua inserção nas demais ferramentas. Através das planilhas eletrônicas, pode-se também executar métodos e procedimentos para os quais não se têm à disposição ferramentas mais eficientes. Esse fato ocorre, por exemplo, no caso do terceiro passo do modelo de demanda, onde é realizado um processo de previsão da escolha dos modos de transporte pelos usuários do sistema. Como não haviam recursos adequados para a utilização de uma ferramenta específica para esse fim, teve-se como alternativa utilizar procedimentos de planilha eletrônica com base nos dados da Pesquisa O/D mencionada anteriormente (item 3.2.4).

\subsection{Procedimentos e métodos adotados}

Diante dos dados, ferramentas e recursos disponíveis, além da experiência adquirida na prática do planejamento urbano na realidade dos países em desenvolvimento, o modelo sequencial de demanda mostrou-se a melhor alternativa para a realização do estudo proposto. Com o objetivo de simplificar o estudo e torná-lo mais acessível, foram utilizados, para sua realização, apenas os recursos e dados que já estavam à disposição ou aqueles de fácil obtenção. Dessa forma procura-se demonstrar a viabilidade do modelo, incentivando o processo de planejamento mesmo quando recursos e dados se mostram relativamente escassos.

Quanto às hipóteses adotadas, foram definidos dois cenários principais. $O$ primeiro toma como base exclusivamente as diretrizes e expectativas do Plano Diretor somadas a poucas observações do padrão de desenvolvimento da cidade até o momento da realização do estudo. Dessa forma, todo o desenvolvimento simulado através do primeiro cenário representa a hipótese de que a cidade siga fielmente as diretrizes do Plano Diretor (cenário "resultado de políticas", conforme classificação de Emmelin, 1995). O segundo cenário, por sua vez, leva em consideração o cadastro de loteamentos da cidade, que contém dados de ocupações intermediárias ao período de estudo, além de informações capazes de 
determinar o padrão das ocupações futuras. Com isso, esses dados, que refletem a situação real da cidade, são priorizados em relação ao proposto no Plano Diretor, respeitando, contudo, suas restrições legais. Isso faz com que o desenvolvimento simulado através do segundo cenário represente a hipótese de que a cidade continue seguindo exatamente o mesmo padrão de crescimento atual (cenário de "tendência natural", conforme classificação de Emmelin, 1995).

O segundo cenário teve seu período de estudo ampliado em relação ao período inicial de previsão do modelo, utilizado para o primeiro cenário. Essa diferença se deve tanto pelo fato do segundo cenário utilizar informações mais recentes em relação ao primeiro, quanto por sua distribuição espacial ocorrer de forma mais uniforme, fazendo com que os impactos resultantes do crescimento fiquem menos evidentes. Dessa forma, aumentando o período de estudo, proporciona-se uma melhor visualização e comparação dos impactos entre o cenário inicial e o resultante. Além disso, dado o intuito do estudo de comparar os resultados quantitativamente, a partir de sua proporção e distribuição geográfica, não há grande prejuízo na comparação dos cenários apesar de representarem períodos diferentes.

Com isso, o primeiro cenário foi definido no período de estudo iniciado no ano de 2000, devido às informações do IBGE, com previsão até o ano de 2020. Já o segundo cenário, com os loteamentos levantados no início de 2010, foi definido no período iniciado no ano de 2000, com previsões estendidas até o ano de 2030 . Os dados e ferramentas à disposição, além do modelo e das hipóteses iniciais definidas, deram origem à seguinte metodologia, de acordo com a Tabela 3.1. 
Tabela 3.1 - Metodologia utilizada.

\begin{tabular}{|c|c|}
\hline 1 & $\begin{array}{l}\text { Preparação dos dados para que possam ser corretamente } \\
\text { interpretados pelos programas TransCAD e What if?; }\end{array}$ \\
\hline 2 & $\begin{array}{l}\text { Definição das áreas a serem consideradas para o processo de } \\
\text { crescimento, no programa What if?; }\end{array}$ \\
\hline 3 & $\begin{array}{l}\text { Definição das projeções de população e emprego para cada } \\
\text { cenário considerado, de acordo com seu respectivo período de } \\
\text { estudo, no programa What if?; }\end{array}$ \\
\hline 4 & $\begin{array}{l}\text { Definição das diretrizes de crescimento, ordenando as áreas } \\
\text { desocupadas através de suas prioridades para ocupação, e, com } \\
\text { todos os parâmetros definidos, o programa What if? computa os } \\
\text { cenários futuros de uso do solo; }\end{array}$ \\
\hline 5 & $\begin{array}{l}\text { Importação dos resultados gerados pelo What if? no programa } \\
\text { TransCAD; }\end{array}$ \\
\hline 6 & $\begin{array}{l}\text { Ajuste dos dados de população e emprego, representando o } \\
\text { número de viagens produzidas e atraídas em cada Zona de } \\
\text { Análise de Tráfego, no programa TransCAD; }\end{array}$ \\
\hline 7 & $\begin{array}{l}\text { Distribuição das viagens entre as zonas, gerando as matrizes } \\
\text { origem/destino, através do modelo gravitacional, no programa } \\
\text { TransCAD; }\end{array}$ \\
\hline 8 & $\begin{array}{l}\text { Cálculo da proporção de viagens realizadas nos diferentes modos } \\
\text { de transporte, obtendo as matrizes origem/destino por modo, com } \\
\text { o uso de planilha eletrônica e do programa TransCAD; }\end{array}$ \\
\hline 9 & $\begin{array}{l}\text { Alocação das viagens, presentes nas matrizes, na rede viária da } \\
\text { cidade, obtendo os fluxos de demanda por viagens entre zonas, no } \\
\text { programa TransCAD; }\end{array}$ \\
\hline 10 & $\begin{array}{l}\text { Visualização dos resultados de uso do solo e de fluxos de } \\
\text { demanda por viagens para os cenários adotados, analisando } \\
\text { visualmente os impactos do processo de crescimento, no programa } \\
\text { TransCAD. }\end{array}$ \\
\hline
\end{tabular}




\section{Capítulo 4 - Aplicação}

De acordo com a metodologia definida no capítulo 3, foi realizada uma aplicação na cidade de São Carlos, cujas etapas são descritas nesse capítulo. A análise do ponto de vista operacional das ferramentas utilizadas é feita posteriormente, no capítulo 5.

\subsection{Preparação: TransCAD}

Primeiramente, utilizando o ambiente SIG do TransCAD, todos os dados disponíveis foram inseridos, georreferenciados e organizados, criando mapas que dispusessem os dados de forma que pudessem ser interpretados adequadamente. Verificaram-se os atributos, valores e sistemas de coordenadas, garantindo assim o correto funcionamento dos arquivos. A partir da classificação de uso do solo dos lotes urbanos, fornecida pelo Plano Diretor (item 3.2.1), gerou-se um mapa agrupando as categorias de uso por quadras, de acordo com seu uso predominante (Figura 4.1). Os usos foram divididos nas categorias: residencial, comercial, industrial, e outros. Essa é uma divisão simplificada em relação àquelas normalmente utilizadas, como em Smith e Saito (2001). Essa simplificação tem como objetivo facilitar a obtenção e utilização dos dados, evitando o uso de informações muito específicas. Por se tratar de um processo de expansão, foi definida uma área envoltória à malha urbana inicial, representando os limites de crescimento dessa malha considerados para a execução do modelo, dado o período de estudo definido. Essa área foi dividida em quadrantes de $100 \mathrm{~m}$ por $100 \mathrm{~m}$ para simular as quadras a serem ocupadas durante o processo de crescimento estimado pelo modelo.

Através do cadastro de loteamentos da cidade, obtido junto à prefeitura do município (item 3.2.6), foi feita a organização dos dados adquiridos, dividindo os loteamentos de acordo com sua situação de aprovação e ocupação. Os loteamentos cadastrados foram divididos nas seguintes categorias: loteamentos aprovados, em aprovação, em fase final de aprovação e loteamentos em fase de ocupação ou já ocupados. Através do mapa assim gerado (Figura 4.2), foram confrontadas as áreas dos loteamentos com as áreas sugeridas pelo Plano Diretor para o desenvolvimento da cidade. Constatou-se, então, que alguns loteamentos já aprovados, ou em fase 
de aprovação, estavam localizados em áreas não recomendadas para assentamento. Porém, tais loteamentos respeitam os limites do perímetro urbano da cidade, além de que muitos dos seus processos de aprovação tiveram início antes da implantação do Plano Diretor, facilitando sua aprovação mesmo que localizados em áreas inadequadas. Daí surgiram as diferenças que refletiram nas hipóteses dos dois cenários adotados.

Com base nos dados obtidos no Plano Diretor sobre as condições de desenvolvimento das áreas não ocupadas ao redor da malha urbana, foram definidas as categorias: áreas adequadas para assentamento, áreas razoáveis para assentamento e áreas não adequadas para assentamento. Com essas informações, criou-se o mapa das condições de desenvolvimento urbano para o primeiro cenário, já que sua hipótese principal é seguir as diretrizes do Plano Diretor. Para o segundo cenário, esse mapa foi modificado, acrescentando-se as áreas onde existiam loteamentos aprovados ou em fase de aprovação, além dos loteamentos em fase de ocupação. Os dois mapas são apresentados na Figura 4.3. Outro mapa que sofreu alterações, devido à citada característica dos loteamentos da cidade, foi o mapa com o padrão de crescimento da cidade, que define uma sequência numérica de ocupação, de forma que as áreas de números mais baixos são mais propensas a ocupação, e assim por diante, até o maior número. O primeiro mapa, representando o primeiro cenário, utiliza as informações do Plano Diretor e algumas características de expansão observadas logo após a sua implementação. Já no segundo mapa, representando o segundo cenário, a sequência foi modificada para se adequar ao padrão dos loteamentos. Os dois mapas são apresentados na Figura 4.4.

Com as informações do IBGE (item 3.2.2) e SEADE (item 3.2.3), foram criadas as Zonas de Análise de Tráfego, adicionando-se às zonas censitárias novas zonas inicialmente desocupadas. Dessa forma, as Zonas de Análise de Tráfego foram definidas de modo que permitissem cobrir toda a área de estudo (Figura 4.5). Nessas zonas foi então contabilizado o número de habitantes e empregos, sendo que para as zonas desocupadas, esses valores permaneceram nulos ao fim dessa etapa. Esse mapa não possui alterações entre os cenários, já que representa apenas as unidades de controle dos dados estimados pelo modelo. Cada um dos mapas gerados nessa etapa de preparação é salvo como shapefile, e os arquivos assim gerados são reunidos em um diretório para que possam ser inseridos no What if? 


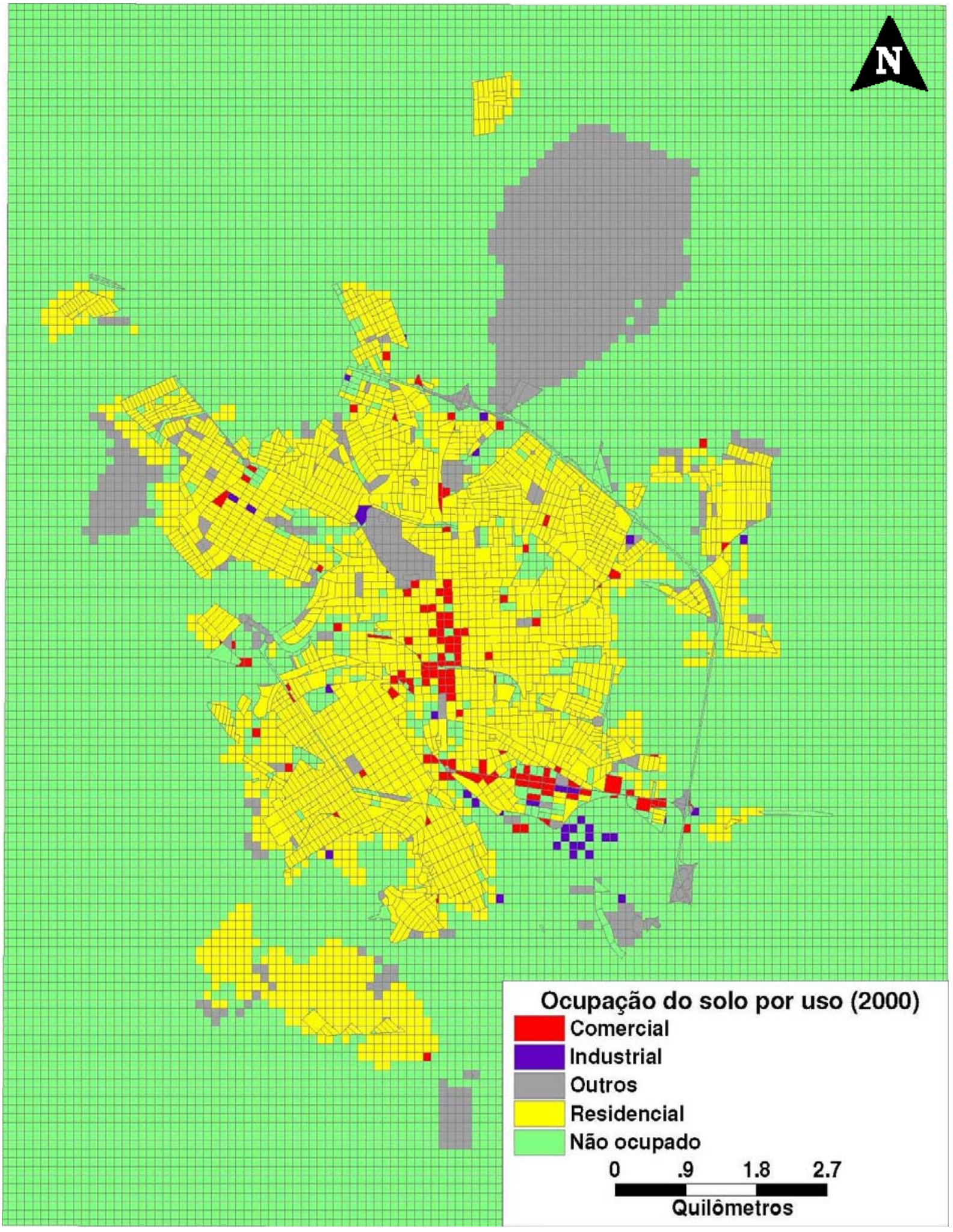

Figura 4.1 - Uso do solo predominante por quadra em São Carlos, 2000. 


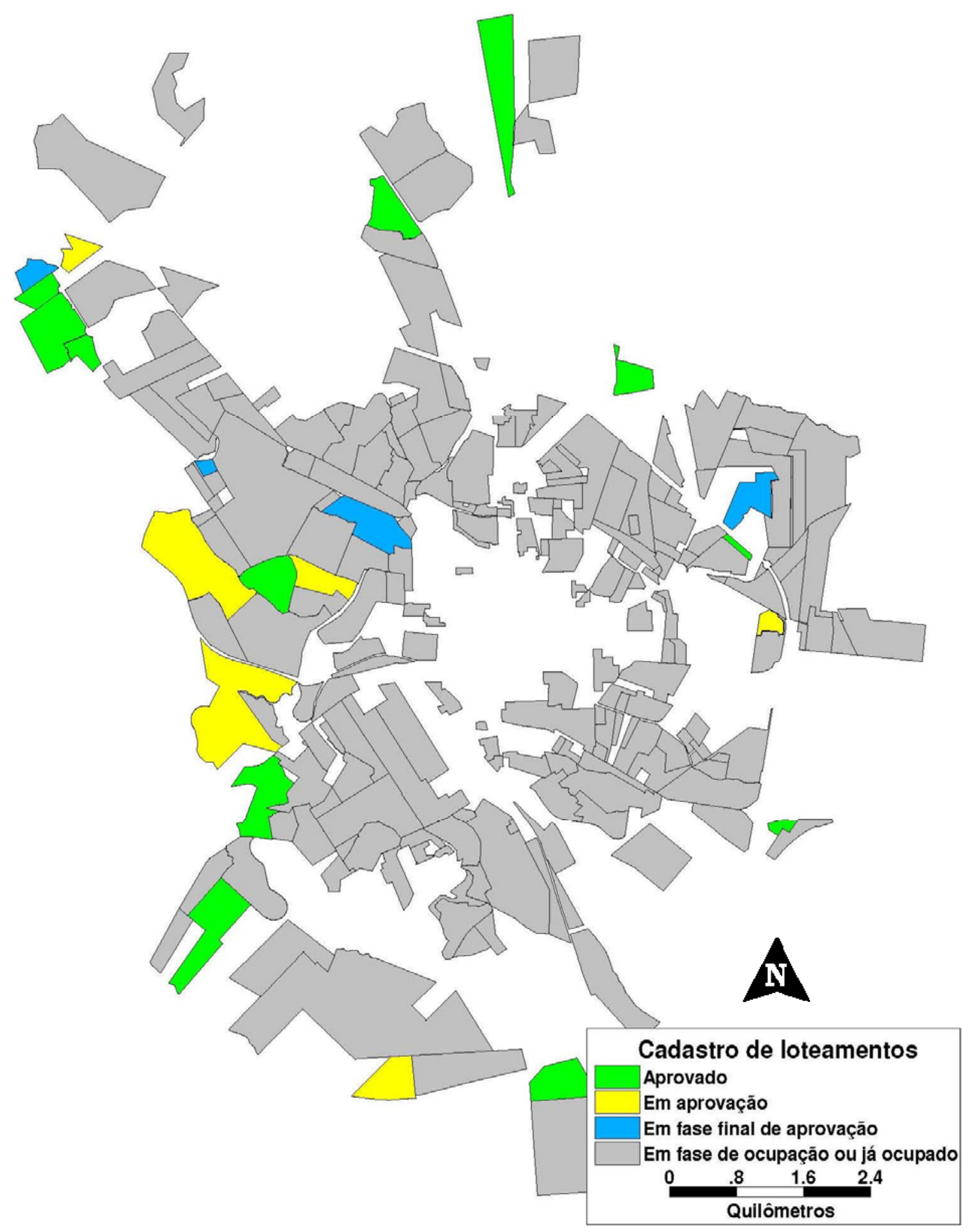

Figura 4.2 - Cadastro dos loteamentos de São Carlos, 2010. 

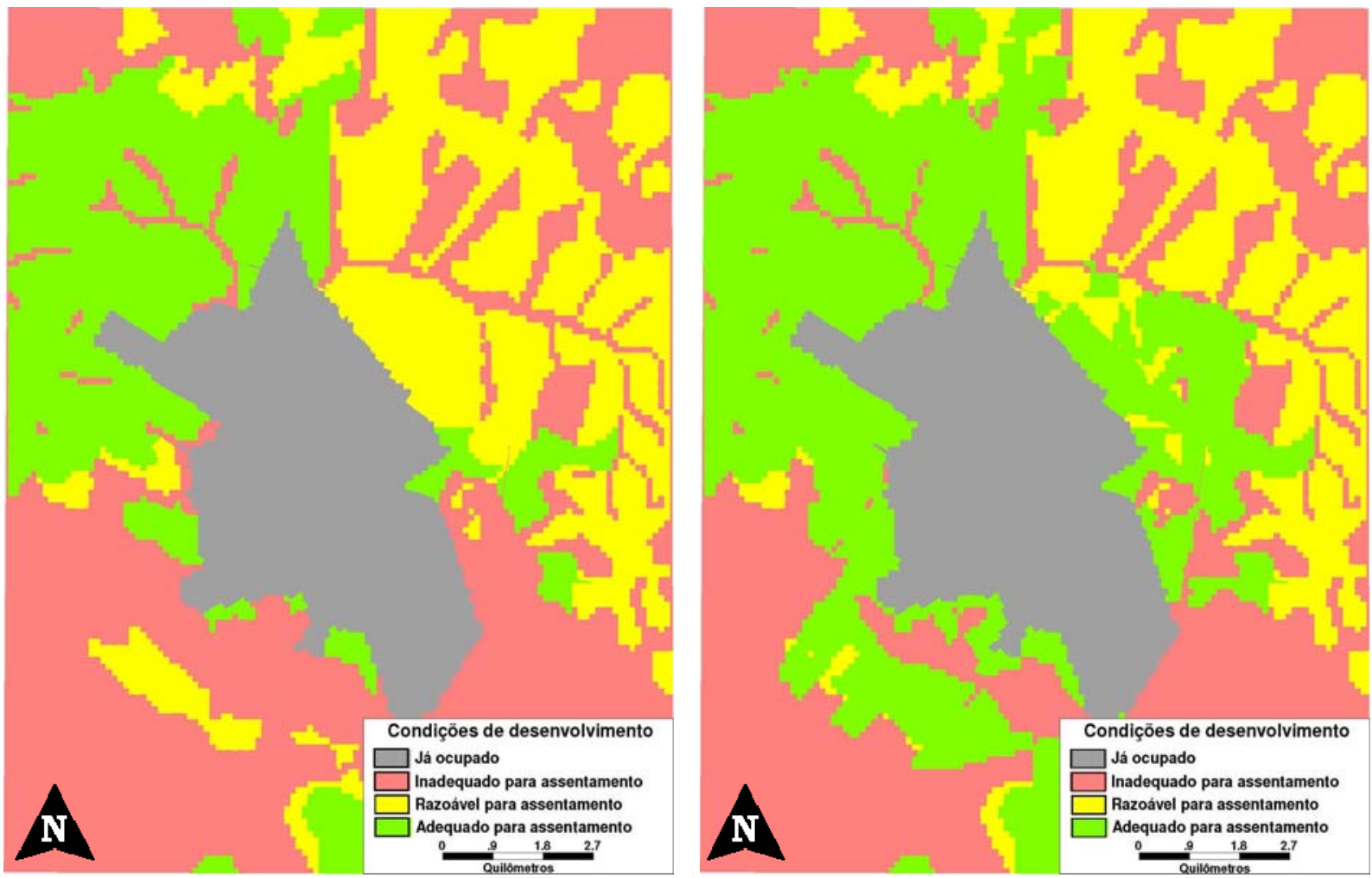

Figura 4.3 - Condições de desenvolvimento urbano para São Carlos, de acordo com os cenários 1 (esquerda) e 2 (direita).
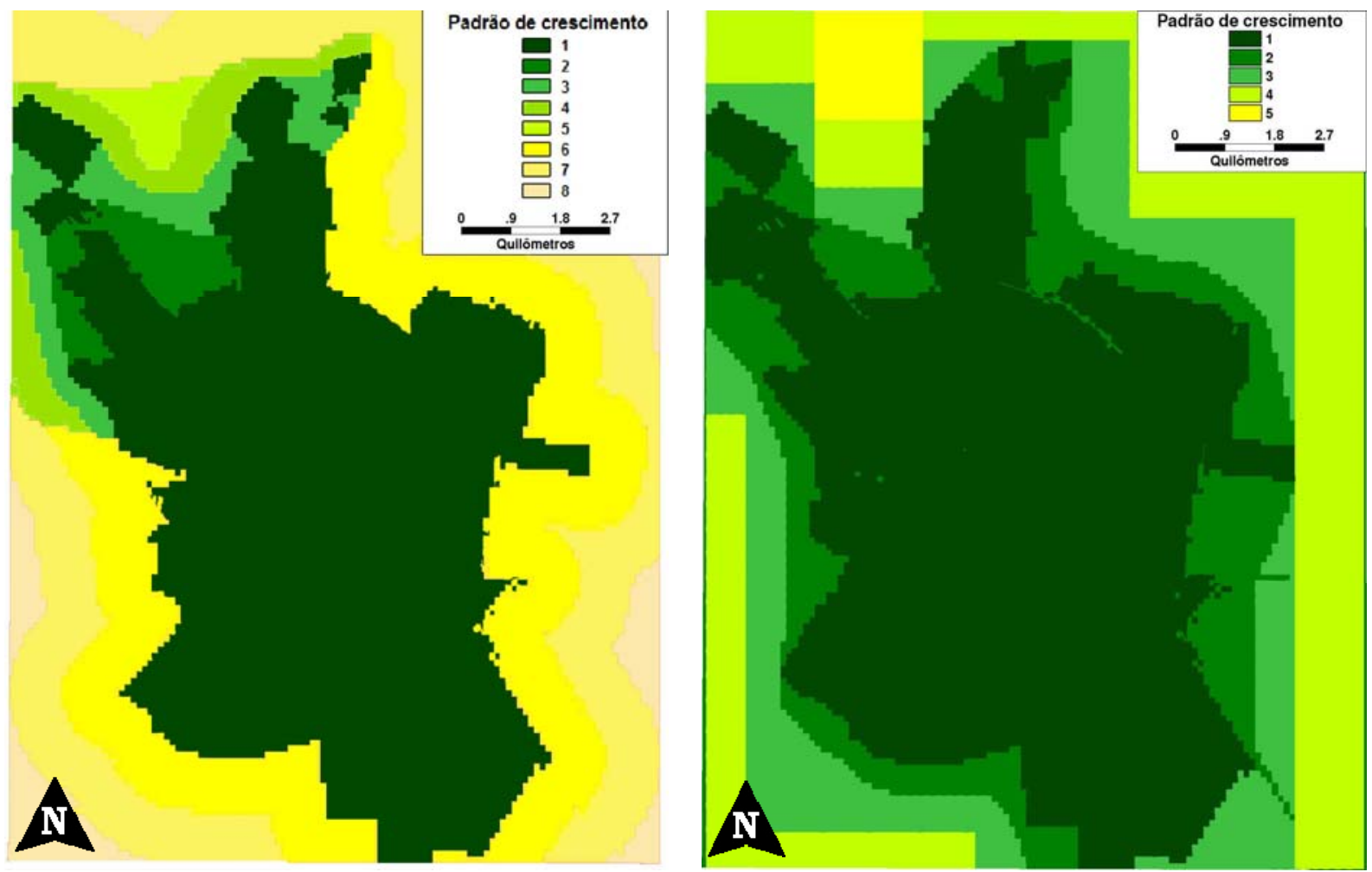

Figura 4.4 - Padrão de crescimento esperado para São Carlos, de acordo com os cenários 1 (esquerda) e 2 (direita). 


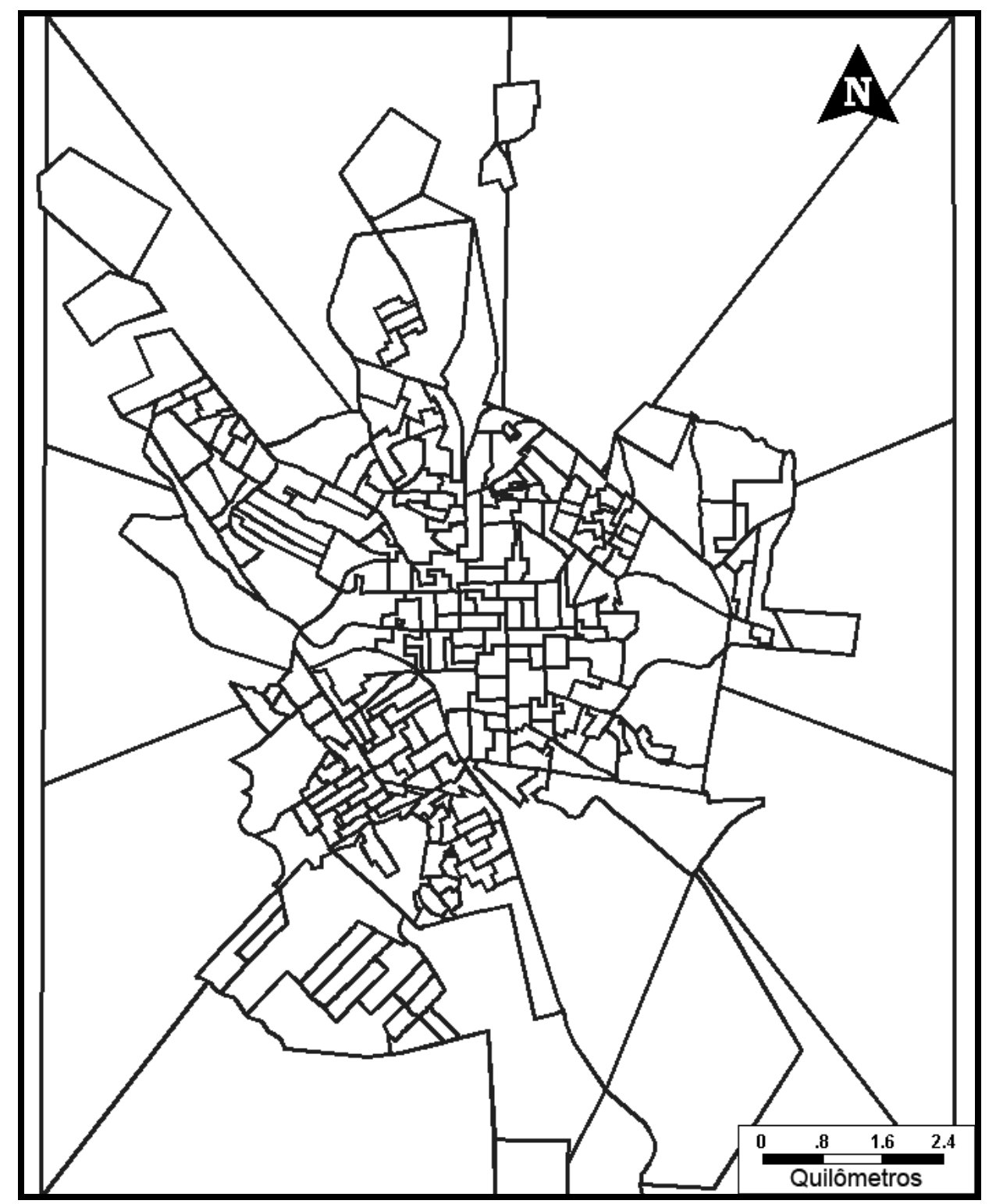

Figura 4.5 - Zonas de análise de tráfego para São Carlos.

\subsection{Previsões futuras: What If?}

Para que novos projetos possam ser criados, o What if? se utiliza da ferramenta What if? Setup para carregar os arquivos a serem utilizados e os preparar para que possam ser corretamente interpretados pelo programa. Concluída essa etapa preliminar, o projeto pode ser então executado na interface principal do programa, cujas ferramentas apresentam um padrão sequencial, dividindo-se em três passos principais.

No primeiro passo foram definidos os parâmetros de ocupação e uso do solo com base no mapa que apresenta as condições de desenvolvimento (Figura 4.3). De acordo com as considerações adotadas, foi definido que as futuras ocupações 
ocorreriam apenas nas áreas adequadas para assentamento. Na sequência foram definidas as projeções de população e emprego divididas em hipóteses de crescimento moderado e acelerado. Esses dados são definidos para cada intervalo, dentro do período de estudo considerado.

Para melhor representar os impactos do crescimento, os resultados apresentados no fim do capítulo refletem apenas as hipóteses de crescimento acelerado. Essas projeções foram obtidas com base nos dados de população e emprego de anos anteriores, considerando as taxas de crescimento estimadas e através de aproximações realizadas em planilha eletrônica. Depois de inseridas essas informações, executou-se o segundo passo, onde foram selecionadas as hipóteses, dentre moderadas e aceleradas, e o programa pôde fazer então os cálculos necessários para o passo seguinte.

Seguindo com o último passo, foram nele definidos os fatores que ordenam a ocupação, fazendo com que determinadas áreas fossem ocupadas antes do que outras. Para isso, definiu-se que fosse considerado pelo programa primeiramente a restrição imposta no primeiro passo, seguida pela informação da sequência de ocupação esperada (Figura 4.4). Finalmente, para áreas que ainda não possuíssem critérios que as diferenciassem, a ocupação foi definida para que ocorresse de forma aleatória.

Com todas as etapas definidas, o programa processou então a demanda por ocupação do solo, alocando os novos usos às áreas disponíveis e gerando os dados de alocação. Esses dados foram computados para cada Zona de Análise de Tráfego, fornecendo os valores projetados de população e emprego para cada intervalo dentro do período de estudo. Para fins das análises aqui apresentadas, no entanto, só foram utilizados os valores de início e fim dos períodos de ambos os cenários. Com isso, o programa gerou os resultados em arquivos no formato shapefile, automaticamente salvos no diretório do projeto.

\subsection{Execução dos quatro passos: TransCAD}

Com os resultados obtidos pelo What if? foi então possível executar, através do TransCAD, o modelo sequencial para o cenário atual e para cenários futuros, podendo-se assim analisar a variação da demanda por transporte no período considerado. Os arquivos gerados pelo What if? continham a população e o número 
de empregos contabilizados para cada Zona de Análise de Tráfego, permitindo que fosse executado o primeiro passo do modelo. De acordo com a Pesquisa O/D (item 3.2.4), o principal motivo de viagem num dia típico da cidade de São Carlos são as viagens de trabalho (originadas nos lotes residenciais com destino aos lotes comerciais e industriais, representando o sentido de ida ao trabalho). Esse tipo de viagem é o que mais se concentra nos horários de pico, provocando os fluxos críticos na rede.

A partir dessas características, o número total de viagens foi dividido em duas categorias: as viagens de trabalho e as demais viagens. Através dos dados da Pesquisa $O / D$, verificou-se que o número referente às demais viagens (segunda categoria) realizadas no horário de pico se mostrou pequeno e equivalente ao número de viagens de trabalho (primeira categoria) realizadas no restante do dia (ou seja, fora do horário de pico). Tem-se assim que o número de viagens de trabalho realizadas durante todo o dia (no pico mais o restante do dia) pôde ser usado para representar o número total de viagens no horário de pico (viagens de trabalho no pico mais as demais viagens no pico), representando os fluxos críticos na rede. Esse procedimento é ilustrado na Figura 4.6.

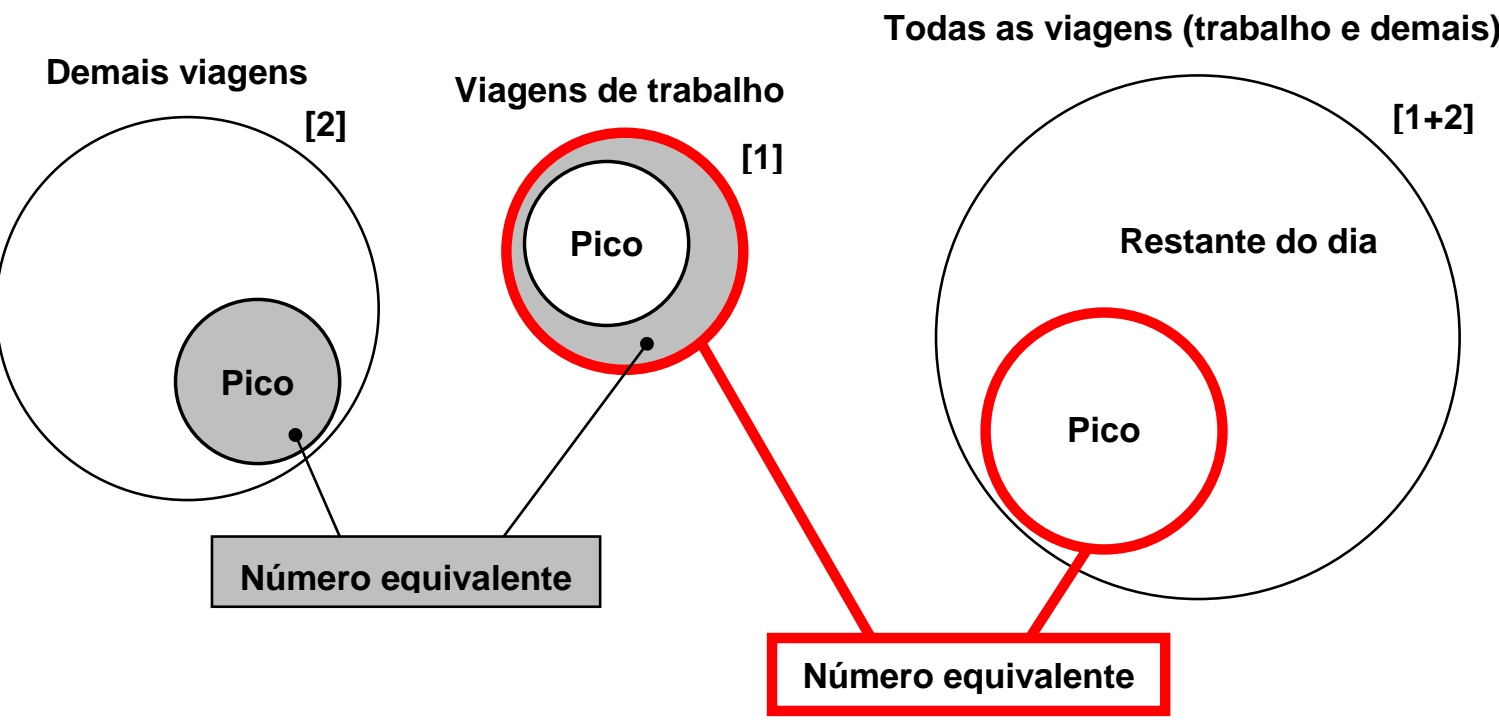

Figura 4.6 - Hipótese de equivalência entre número de viagens.

Essa hipótese permite estimar todas as viagens realizadas no horário de pico a partir apenas das viagens de trabalho, simplificando bastante a execução do modelo. Verificando-se a equivalência desses valores através dos dados da 
Pesquisa O/D, obteve-se um erro da ordem de 5\%, considerado bastante satisfatório de acordo com o nível de precisão almejado. Outra característica interessante a favor dessa hipótese é que, de acordo com Mohammadian e Zhang (2007), as estatísticas baseadas nos motivos de viagem apresentam boa capacidade de transferência para outras cidades, fazendo com que a hipótese possa ser largamente utilizada.

A geração de viagens foi então estimada com base na população de cada zona, para a produção de viagens, e com base no número de empregos também de cada zona, para a atração de viagens. Em seguida foi feito um balanceamento dos vetores população e emprego para igualar o número total de viagens produzidas ao número máximo de empregos disponíveis, representando o número máximo de viagens de ida ao trabalho.

Diante do número de viagens produzidas e atraídas em cada zona de tráfego partiu-se para o segundo passo, realizando a distribuição das viagens através do modelo gravitacional. Para isso foram utilizadas equações e constantes calibradas de forma que pudessem representar o comportamento das viagens na cidade de São Carlos. Primeiramente, construiu-se a matriz de custo, onde foi considerada como custo a distância entre os centróides das zonas de tráfego e, a partir de uma equação, determinaram-se as distâncias médias internas de cada zona, representando o custo das viagens com origem e destino na mesma zona. Então, com base na matriz de custo e num fator de atrito (constante gravitacional) previamente calibrado (num primeiro momento para uma cidade com características semelhantes e depois para São Carlos), foram processadas, através da aplicação do modelo gravitacional pelo método da potência inversa, o número de viagens com origem e destino em cada Zona de Análise de Tráfego.

Para o terceiro passo, apesar de o TransCAD possuir ferramentas para a atribuição da escolha modal, esse processo exigiria dados ou considerações de maior complexidade. Isso consumiria recursos de forma excessiva para um estudo cujo objetivo principal não é definir o número exato de viagens, mas avaliar o aumento da demanda por viagens em função do crescimento da cidade. Portanto, foi definida uma proporção de uso modal de acordo com os dados percentuais gerais, levantados na Pesquisa O/D, simplificando assim o processo, mas mantendo ainda um número coerente de viagens. Esse processo foi feito multiplicando-se a matriz 
O/D principal, que representa o número total de viagens, pela porcentagem de viagens realizadas em cada modo considerado, gerando submatrizes O/D.

Partiu-se então para o quarto passo, através do qual as viagens puderam enfim ser alocadas à rede viária. Nesse ponto, foram utilizadas apenas as viagens realizadas através do modo ônibus, representando um dos principais focos abordados pelo modelo, dado seu caráter social. Para tanto, a rede viária foi previamente restrita ao conjunto de rotas pelas quais trafegam os ônibus que realizam o transporte público da cidade, representando as vias que possuem infraestrutura para comportar este modo. Além disso, foi preciso incluir na rede, vias de acesso às novas áreas, conectando os centróides das novas zonas, através de segmentos fictícios. Executou-se então a alocação do tráfego pelo método básico do "tudo ou nada", obtendo as rotas de menor distância e finalmente os fluxos estimados nas vias.

\subsection{Resultados obtidos}

Com a conclusão dos procedimentos descritos, é possível enfim obter os resultados do estudo, que podem ser divididos em dois níveis de análise: os cenários futuros de ocupação, obtidos com o What if?, e os fluxos de tráfego para estes cenários e para o cenário atual, obtidos com o TransCAD. Ambos os programas possuem ferramentas para apresentar seus resultados na forma de mapas, através dos quais se faz possível a realização de análises visuais, tanto pelos planejadores envolvidos quanto pelos tomadores de decisão. Entretanto, todos os resultados aqui apresentados foram gerados através das ferramentas do TransCAD.

\subsubsection{What if?: Cenários futuros de ocupação e uso do solo}

Apresentam-se aqui os mapas de ocupação e uso do solo gerados para o cenário 1 (Figura 4.7), representando as políticas do Plano Diretor estimadas para o ano de 2020, e para o cenário 2 (Figura 4.8), representando as tendências de ocupação dos loteamentos atuais da cidade projetadas para o ano de 2030. Para efeitos de análise, a melhor visualização desses resultados se dá quando os mapas são apresentados em conjunto com a situação inicial, ilustrada no mapa da ocupação referente ao ano de início do período, que em ambos os casos foi definido 
para o ano de 2000 (Figura 4.1). Através dos mapas, é possível perceber nitidamente a grande expansão da malha urbana que, para o primeiro cenário, se dá em sua região noroeste, de acordo com as diretrizes estabelecidas pelo Plano Diretor. Já para o segundo cenário, a expansão se dá de forma distribuída, obedecendo ao plano de loteamentos cadastrados na cidade. Mais considerações acerca desses resultados e das diferenças obtidas são apresentadas no item 6.1.

\subsubsection{TransCAD: Fluxos de tráfego}

Cada situação de ocupação do solo permitiu a respectiva execução do modelo de demanda por viagens proposto e sua consequente associação dos fluxos de tráfego à rede viária. Para efeitos de análise, os mapas de fluxo de viagens também são visualizados mais adequadamente quando apresentados em conjunto com a situação inicial. Esses mapas foram gerados utilizando-se uma ferramenta de visualização do TransCAD que representa os fluxos nas vias de acordo com uma escala de proporção, onde a espessura de cada via é proporcional ao volume de tráfego associado a ela.

A seguir, são apresentados os mapas com os fluxos de viagens iniciais (Figura 4.9), os fluxos de viagens gerados no cenário 1 (Figura 4.10) e os fluxos de viagens gerados no cenário 2 (Figura 4.11). Os mapas foram gerados na mesma escala, permitindo a análise visual do acréscimo dos fluxos de viagem da situação inicial para as situações previstas ao término dos períodos de estudo. Através dos mapas percebe-se claramente o grande aumento das viagens, principalmente na região noroeste, em ambos os cenários, e também no eixo central ao sul, mais acentuadamente no segundo cenário. Mais considerações acerca desses resultados e das diferenças obtidas são apresentadas no item 6.1. 


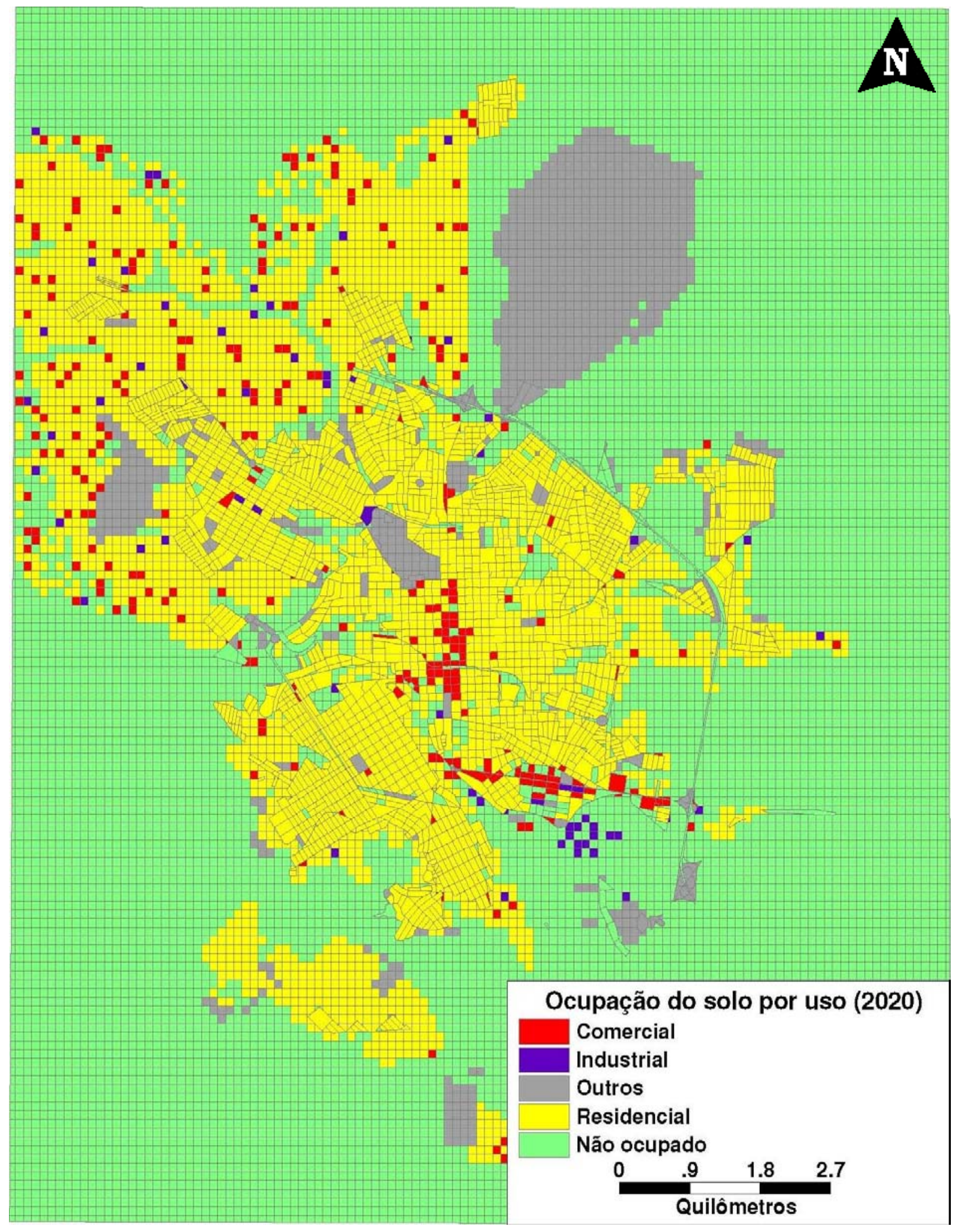

Figura 4.7 - Projeções de uso do solo para São Carlos, 2020. 


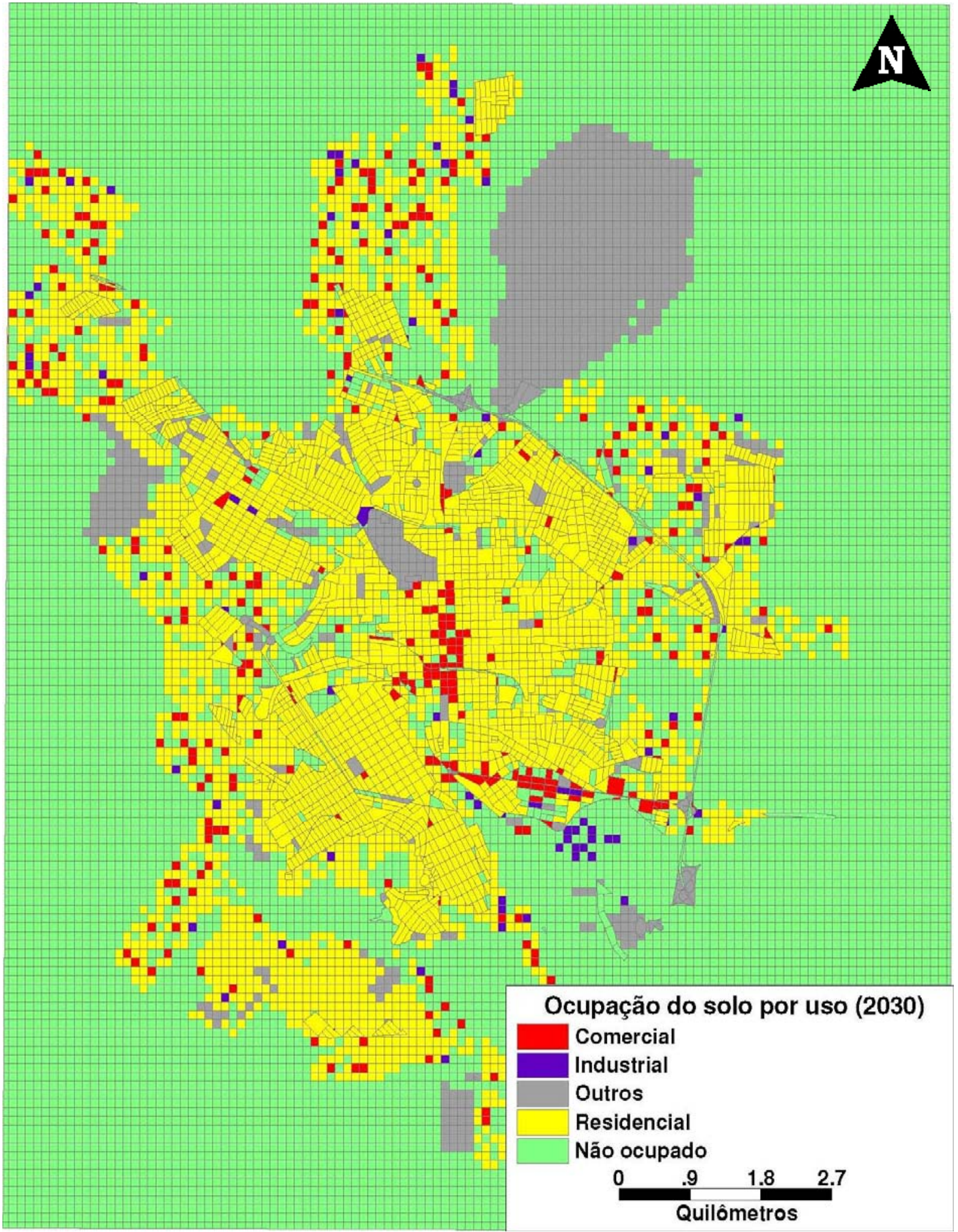

Figura 4.8 - Projeções de uso do solo para São Carlos, 2030. 


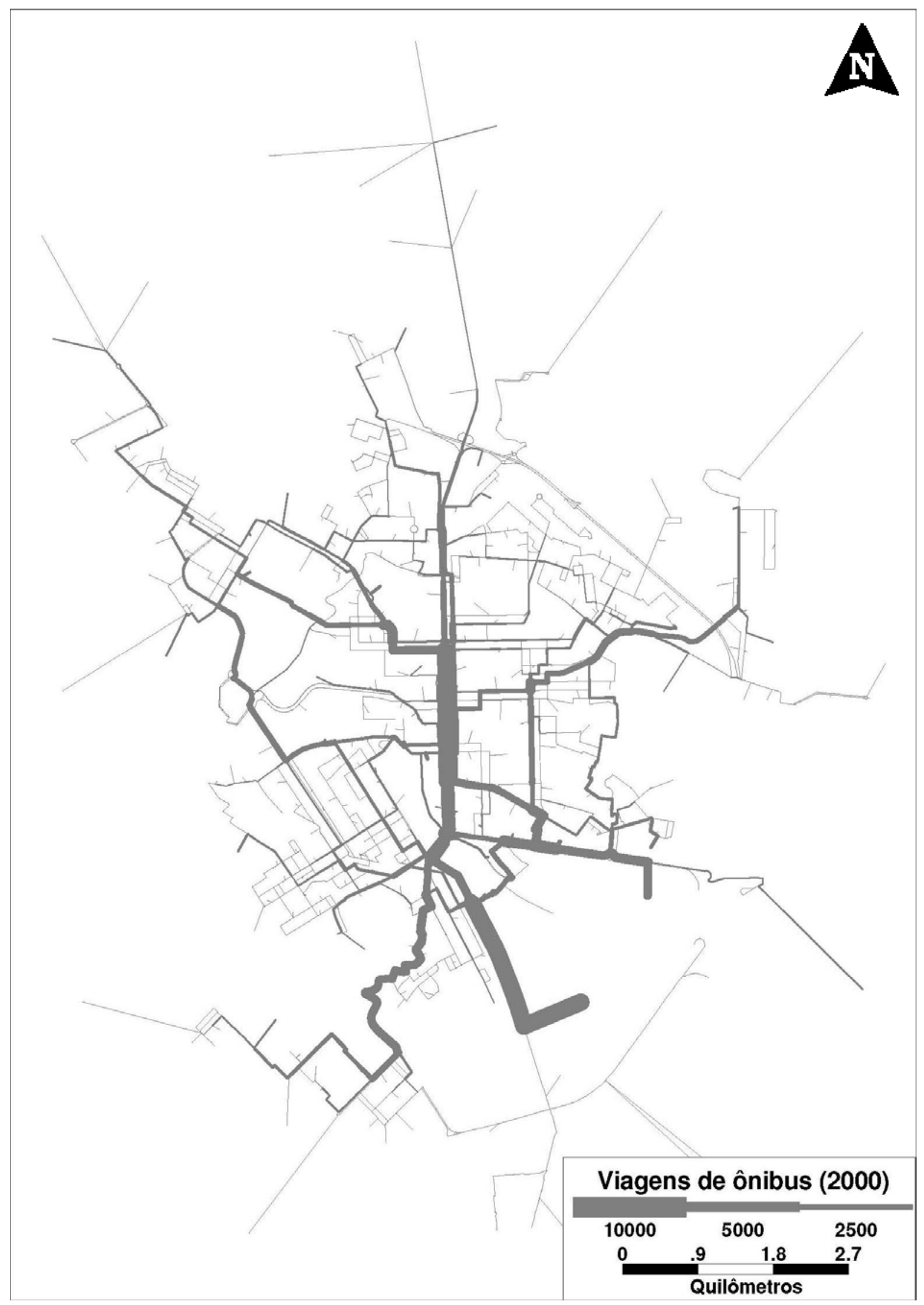

Figura 4.9 - Projeções dos fluxos de viagem por ônibus para São Carlos, 2000. 


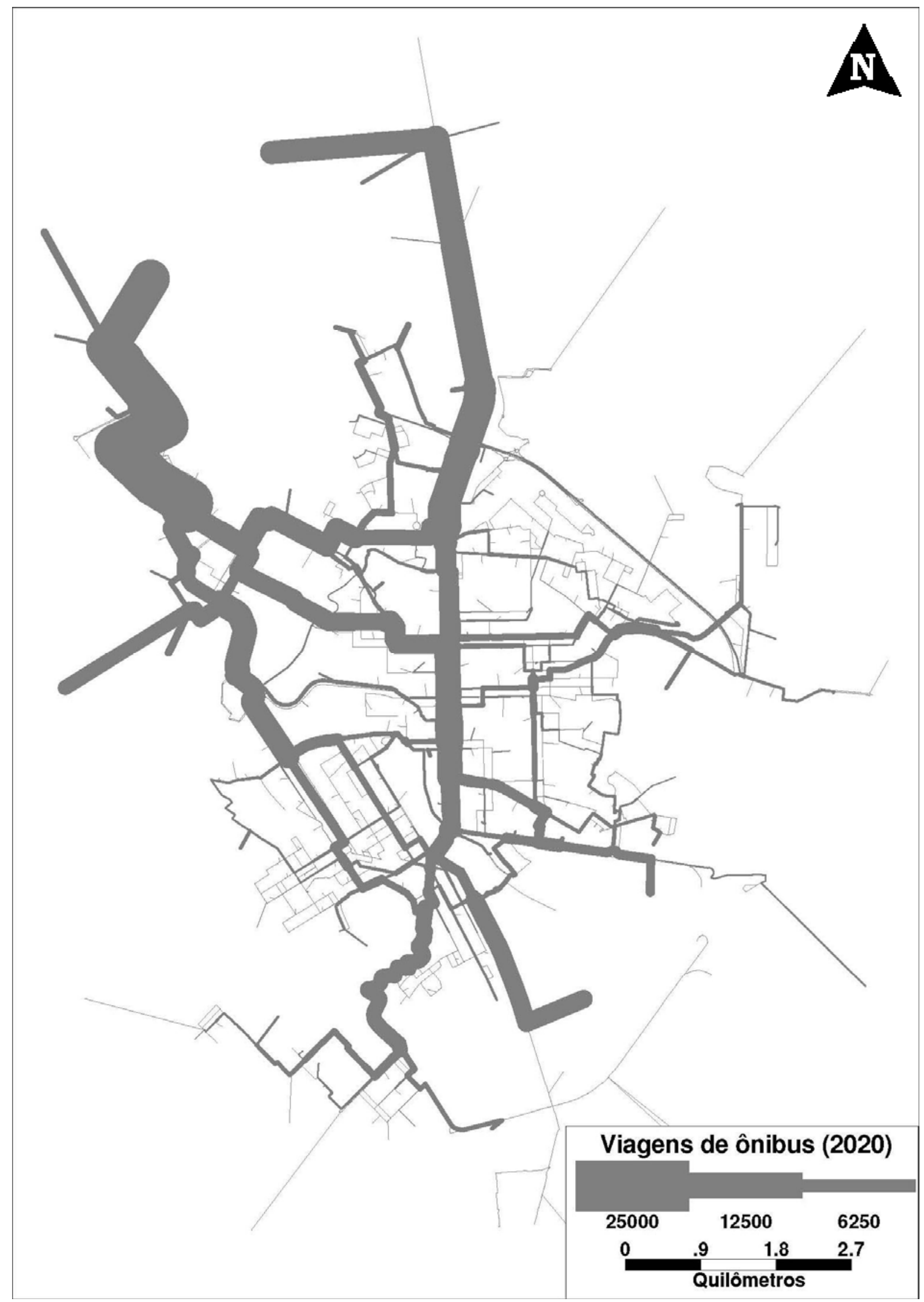

Figura 4.10 - Projeções dos fluxos de viagem por ônibus para São Carlos, 2020. 


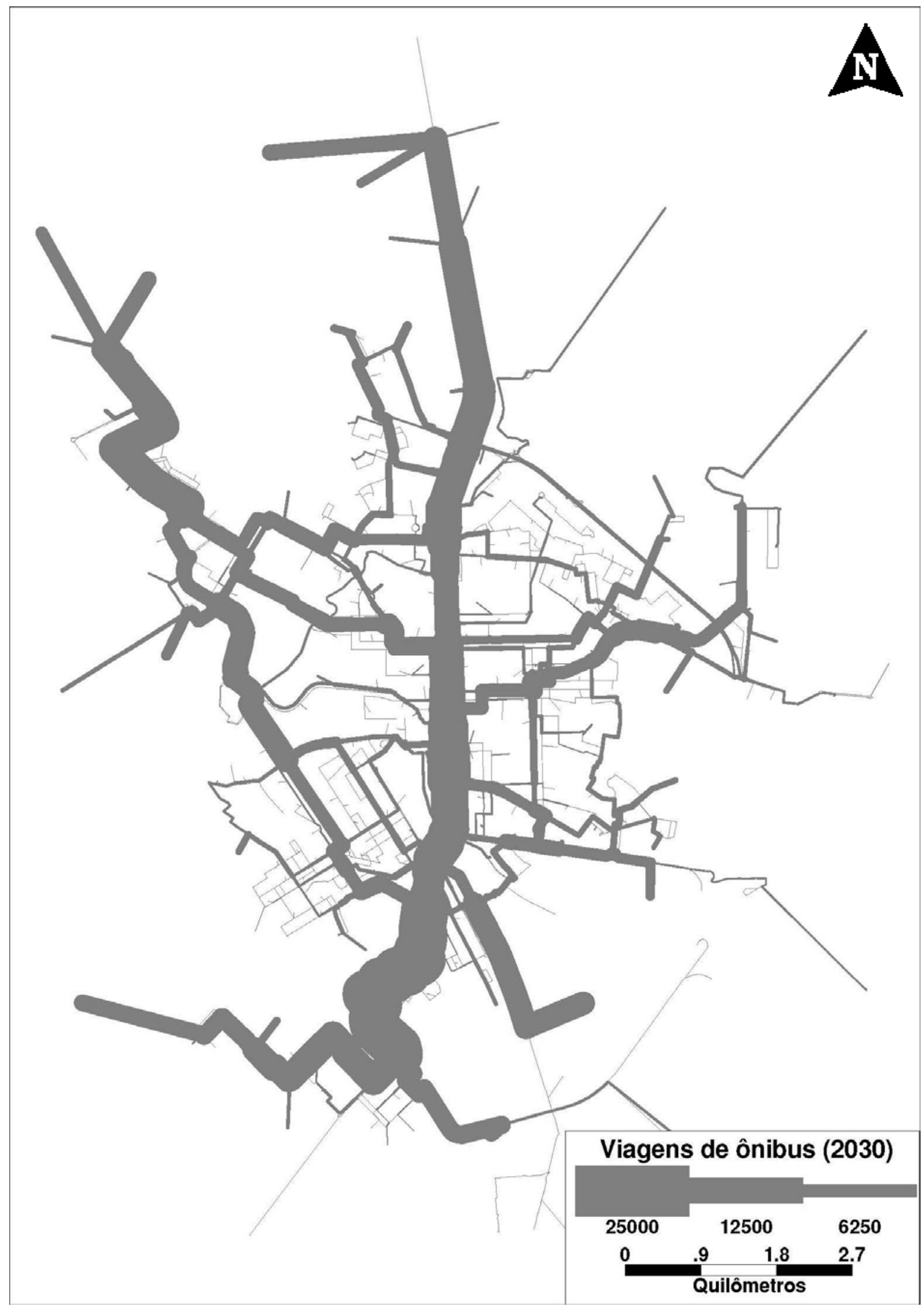

Figura 4.11 - Projeções dos fluxos de viagem por ônibus para São Carlos, 2030. 


\section{Capítulo 5 - Ferramentas computacionais}

Com base na aplicação apresentada no capítulo 4 é feita uma avaliação do desempenho das ferramentas e programas utilizados, levando em conta suas características operacionais e a qualidade dos dados produzidos ao longo das etapas do modelo. Procura-se dessa forma investigar mais detalhadamente os requisitos operacionais de cada ferramenta, tanto em termos dos dados utilizados, quanto em relação ao nível de complexidade exigido para executar seus cálculos e operações. São assim reunidos argumentos no sentido de incentivar e facilitar o uso de ferramentas de planejamento urbano adequadas às condições específicas dos países em desenvolvimento. Da mesma forma, tais argumentos buscam auxiliar o processo de adaptação e desenvolvimento de novas ferramentas, tema abordado ao fim do capítulo, onde se faz uma reflexão sobre como esse processo se mostra desejável e promissor.

\subsection{As ferramentas utilizadas na aplicação do modelo}

Neste item são descritas todas as ferramentas utilizadas na aplicação do modelo apresentada no capítulo 4, divididas em grupos de acordo com as principais etapas do modelo adotado. Esses grupos dividem as ferramentas nas etapas de Preparação, Projeções futuras de uso do solo, Modelo sequencial de demanda por transportes e Visualização e análise dos resultados, além dos grupos auxiliares de Calibração e Ferramentas de suporte. Assim como os procedimentos pertencentes a cada etapa, as próprias etapas entre si seguem um padrão sequencial, orientando e organizando o estudo desde os dados iniciais até os resultados finais. Essa sequência de procedimentos é apresentada através do fluxograma da Figura 5.1, onde as ferramentas e fontes de dados são enumeradas de acordo com seus respectivos itens dos capítulos onde são descritas. A legenda com a simbologia e o esquema de cores utilizados no fluxograma é apresentada na Figura 5.2. 


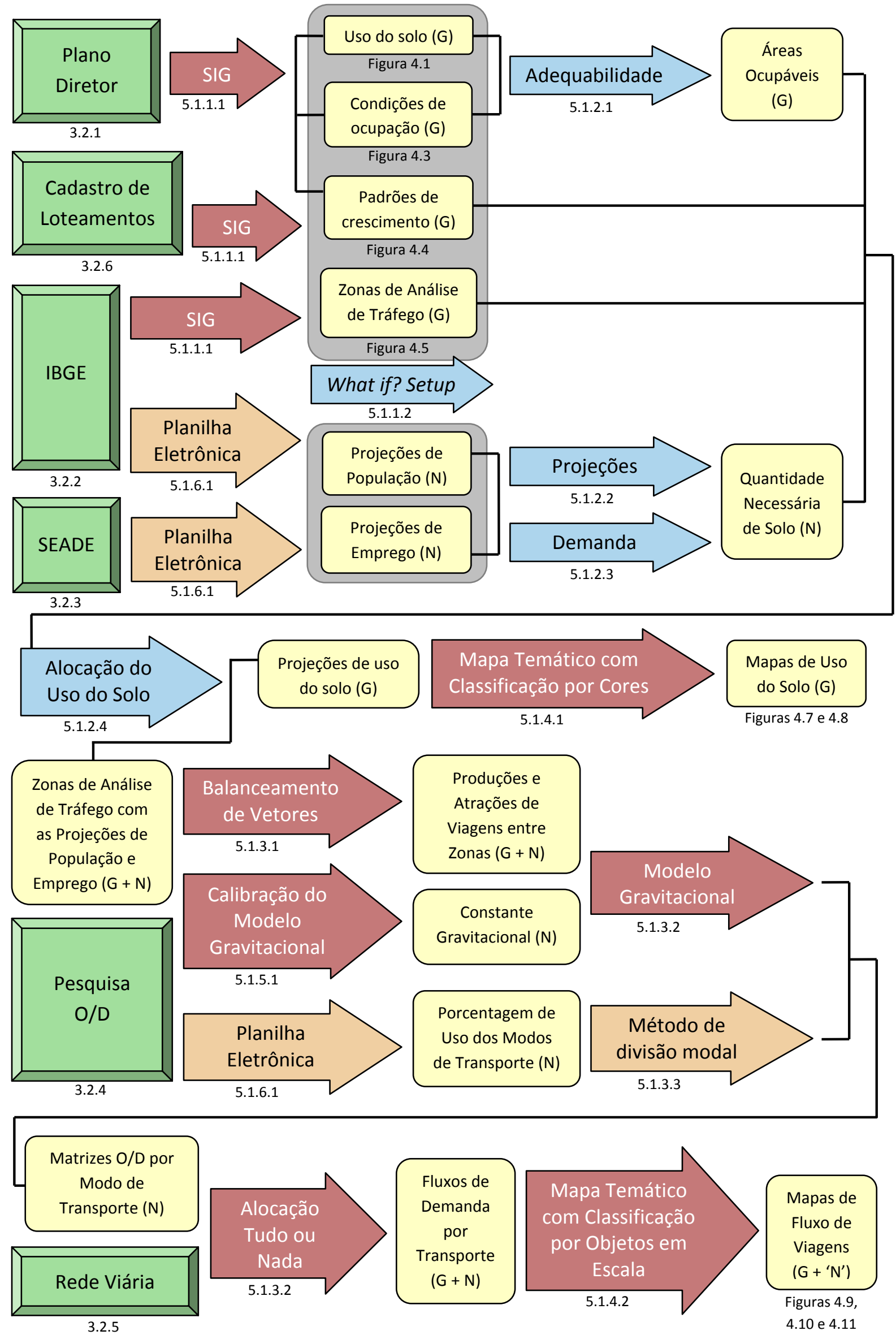

Figura 5.1 - Fluxograma geral de procedimentos do modelo proposto. 


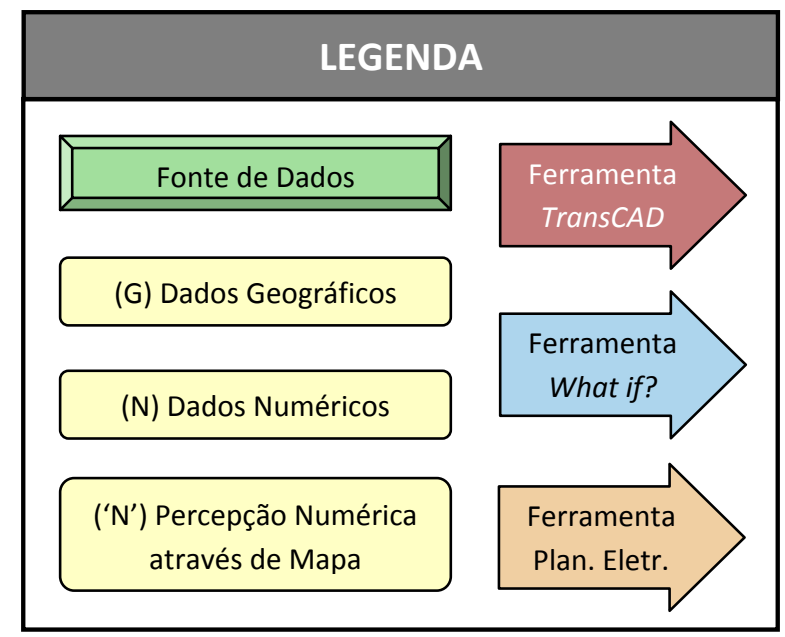

Figura 5.2 - Simbologia utilizada no Fluxograma.

\subsubsection{Preparação}

É natural que os dados iniciais obtidos para a execução do modelo apresentem-se sob diversas formas, como imagens, tabelas, ou outros arquivos gerados por programas específicos. Desse modo, é necessária uma etapa inicial onde todos esses dados são reunidos e trabalhados para que se adaptem às demais ferramentas do modelo.

\subsubsection{Sistema de Informações Geográficas}

A primeira e mais importante ferramenta para a realização do estudo é sem dúvida o SIG. Com ele é possível organizar todos os dados disponíveis, criando uma base sólida para diversos tipos de análise. A ferramenta SIG funciona como base de muitos programas computacionais que têm como função desde o cadastro e a documentação de informações como clientes, produtos, rotas e mapas urbanos, até a execução de procedimentos específicos como otimizações, estudos de viabilidade e diversas atividades de planejamento. Através da sua capacidade de visualização e análise espacial, o SIG se mostra uma valiosa ferramenta para identificar e entender os problemas e necessidades da área estudada (AL-KODMANY, 1999). Devido ao grande potencial das ferramentas SIG para o planejamento em transportes, muitos programas computacionais vêm sendo desenvolvidos para trabalhar em ambientes SIG-T. Esse ambiente utiliza as funcionalidades de um SIG em conjunto com ferramentas específicas para problemas logísticos e de transportes. 
No início do processo de planejamento aqui proposto, mostra-se fundamental a utilização de um programa computacional que possua as funcionalidades de um SIG, independentemente da escolha entre um SIG ou SIG-T, visto que sem o uso dessa ferramenta o processo se tornaria demasiadamente trabalhoso e ineficiente. Apenas para análises muito simples ou para áreas muito pequenas seria justificável a não utilização de um SIG. Para a aplicação apresentada no capítulo 4 foi utilizada a interface SIG do programa TransCAD, que atendeu muito bem às necessidades da etapa de preparação dos dados, gerando os arquivos geográficos necessários para o prosseguimento do modelo.

Nessa etapa foram utilizadas diversas ferramentas de busca, seleção, edição e inserção de dados na interface SIG. Dentre as principais funções, foram criados elementos de área, tanto manualmente quanto através da geração de malha, foi feita contagem de pontos, de acordo com suas localizações, e foram inseridos dados a elementos de área através de seleções, tanto manuais quanto automáticas, condicionadas a parâmetros. Além disso, o programa oferece suporte para sistemas de coordenadas e mecanismos para importar e exportar arquivos de diferentes extensões.

Essas ferramentas não são aqui apresentadas detalhadamente, pois se tratam apenas de procedimentos de manipulação e organização dos dados, o que pode ser feito de diversas formas. Sendo assim, todas essas ferramentas foram consideradas como parte da ferramenta SIG, apesar de que cada programa que trabalhe com um ambiente SIG tem suas ferramentas específicas, podendo atender ou não às necessidades do modelo aqui proposto. Todas as ferramentas do TransCAD utilizadas na etapa de preparação e nas demais etapas do estudo (itens 5.1.3, 5.1.4, 5.1 .5 e 5.1.6) são acessadas a partir da interface principal do programa (Figura 5.3). 


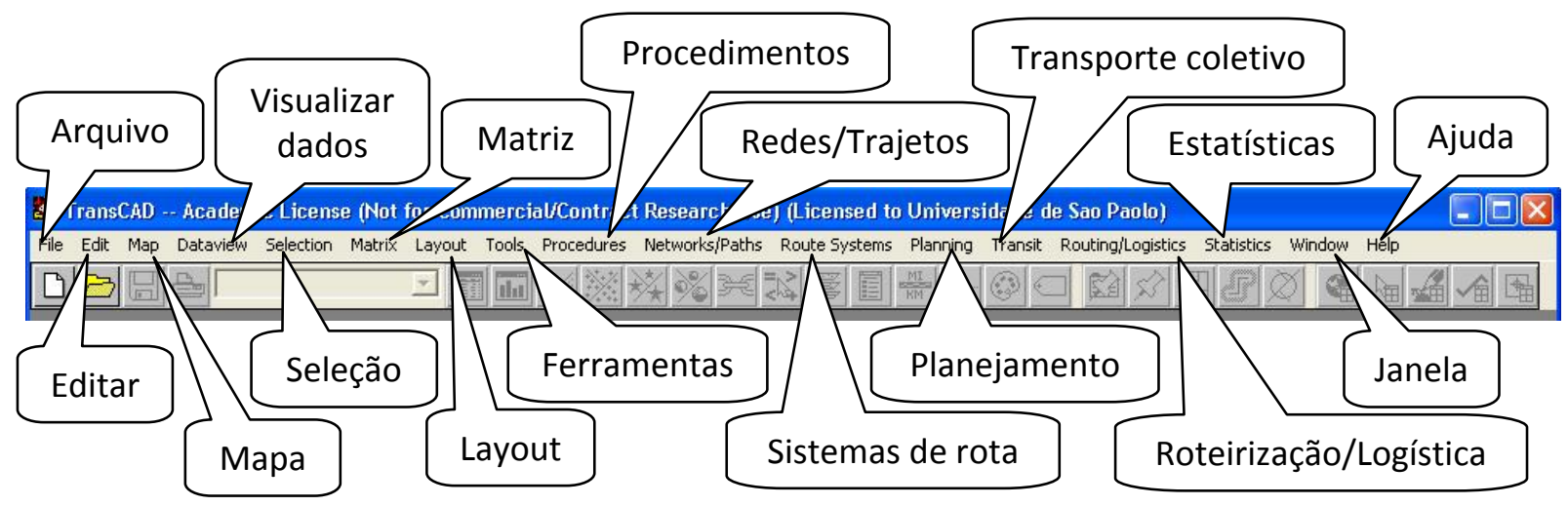

Figura 5.3 - Comandos do menu principal do TransCAD.

\subsubsection{What if? Setup}

Ainda na etapa inicial de preparação dos dados, foi necessária a utilização da ferramenta What if? Setup (Figura 5.4) para que os arquivos geográficos preparados no TransCAD pudessem ser utilizados no programa What if?. Com essa ferramenta, cada arquivo é associado de acordo com sua finalidade, sendo definidas suas variáveis e níveis de classificação. São assim associadas ao ambiente SIG do What if? as informações de uso do solo, adequabilidade para uso futuro do solo, população, emprego, controle de alocação do uso do solo e finalmente as subáreas de estudo (zonas de análise de tráfego). São também inseridos os dados que definem o período de análise do estudo e as unidades de medida a serem utilizadas pelo programa. Esses procedimentos têm como finalidade traduzir os dados para que possam ser compreendidos pelo programa. Dessa forma, as próximas etapas podem ser realizadas de modo mais automático e organizado. Concluída essa etapa, o What if? Setup gera os arquivos necessários para que o projeto seja executado na interface principal do What if? (Figura 5.5) para a execução das projeções futuras de uso do solo. 


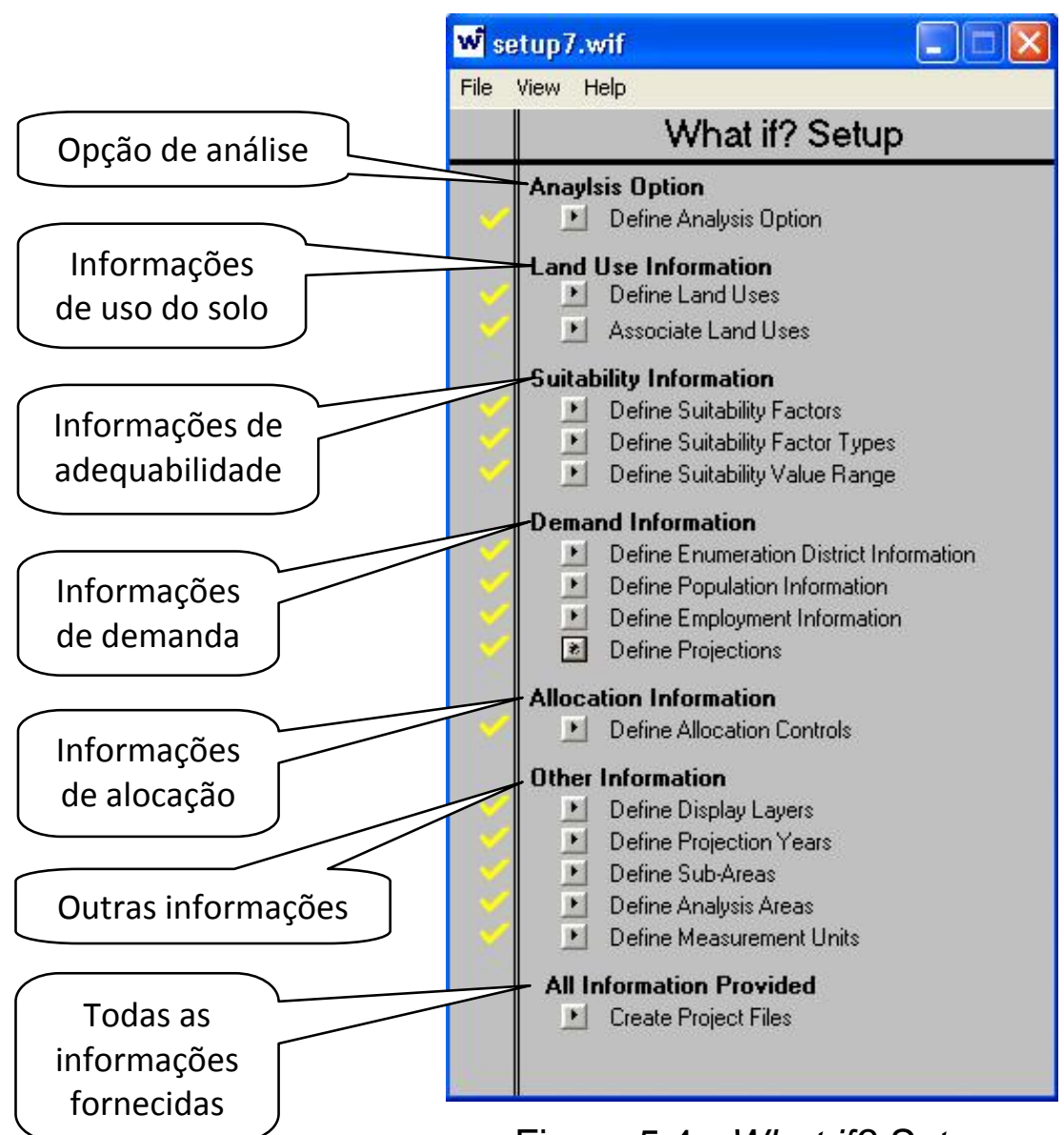

Figura 5.4 - What if? Setup

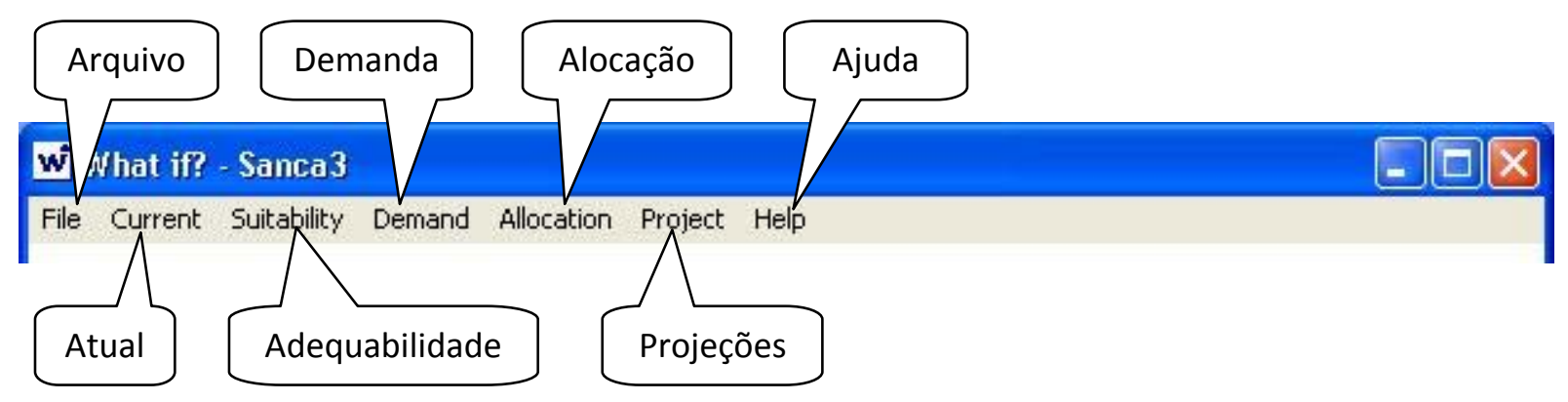

Figura 5.5 - Comandos do menu principal do What if?

\subsubsection{Projeções futuras de uso do solo}

Para essa etapa, foram utilizadas quatro ferramentas presentes no programa What if?: Adequabilidade (Suitability), Projeções (Project / Values), Demanda (Demand) e Alocação do Uso do Solo (Allocation), todas elas se referindo às características urbanas iniciais de ocupação e uso do solo e suas projeções futuras. A obtenção da ocupação futura na área de estudo depende da execução de todas as quatro ferramentas, representando três passos principais (Adequabilidade, 
Demanda e Alocação do Uso do Solo) e um passo auxiliar (Projeções) que atua em conjunto com a ferramenta Demanda.

\subsubsection{Adequabilidade}

Com a ferramenta Adequabilidade (Figura 5.6), divide-se a área de estudo em áreas onde a ocupação é cabível ou não. É possível definir, ainda, quais são as áreas mais ou menos adequadas para a ocupação e, em caso de vários fatores condicionantes, especificar quais fatores têm mais ou menos importância. Há também a opção de se criar diferentes padrões de adequabilidade do solo, de acordo com as políticas de desenvolvimento a serem consideradas. Porém, esses procedimentos adicionais não foram utilizados na aplicação. Da forma como foi utilizada, essa ferramenta executa um procedimento extremamente simples, que pode ser inclusive realizado apenas com as funcionalidades do SIG.

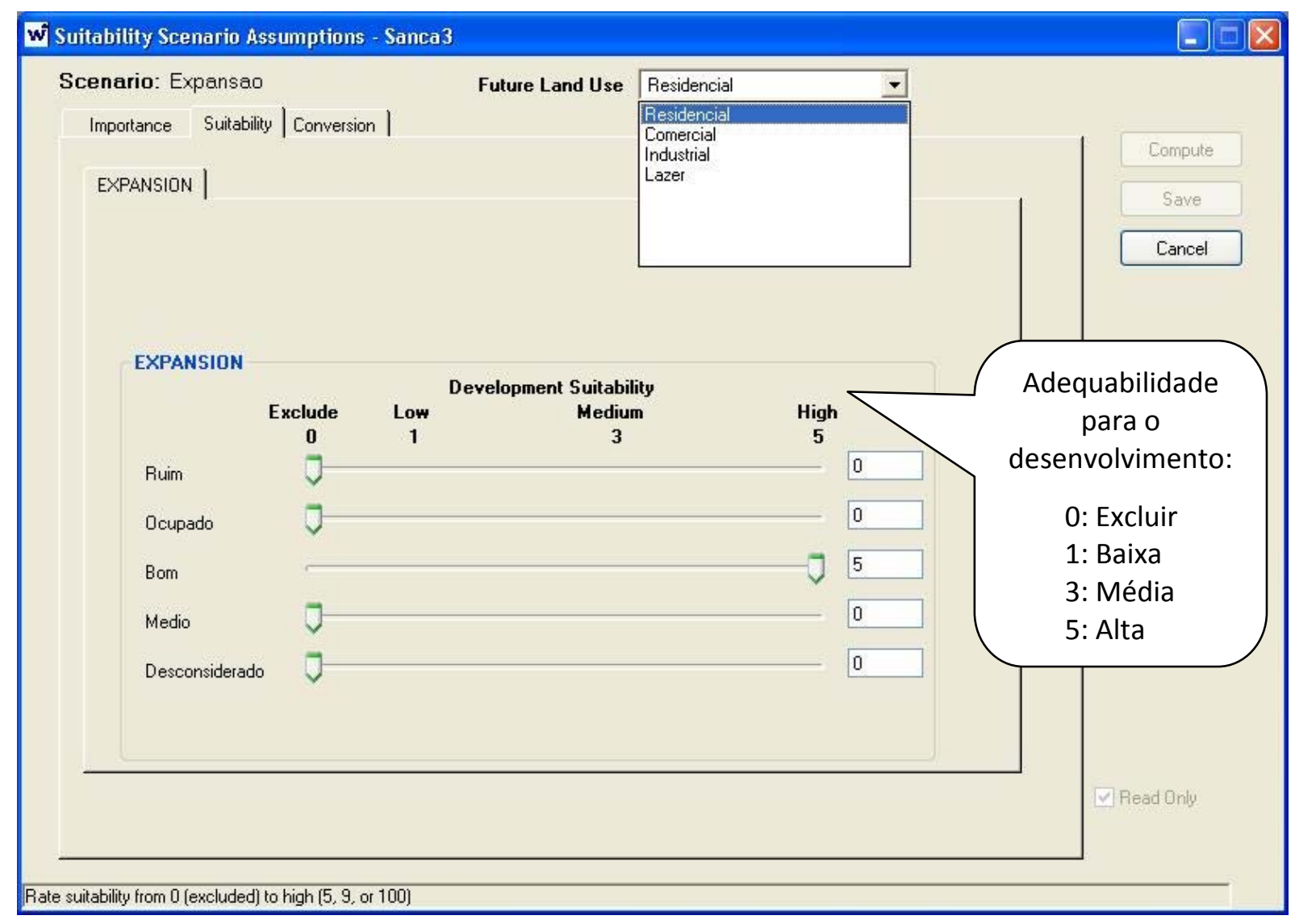

Figura 5.6 - What if? - ferramenta Adequabilidade (Suitability). 


\subsubsection{Projeções}

Com a ferramenta Projeções (Figura 5.7), são adicionados ao programa os números totais de habitantes e empregos previamente estimados em planilha eletrônica, de acordo com as taxas anuais de crescimento consideradas. Esses números representam o total de habitantes da região urbana e o total de empregos para cada um dos setores de atividades considerados, sendo definidos para cada intervalo de tempo dentro do período de estudo. No caso da Figura 5.7, o período foi dividido em intervalos de 10 anos.

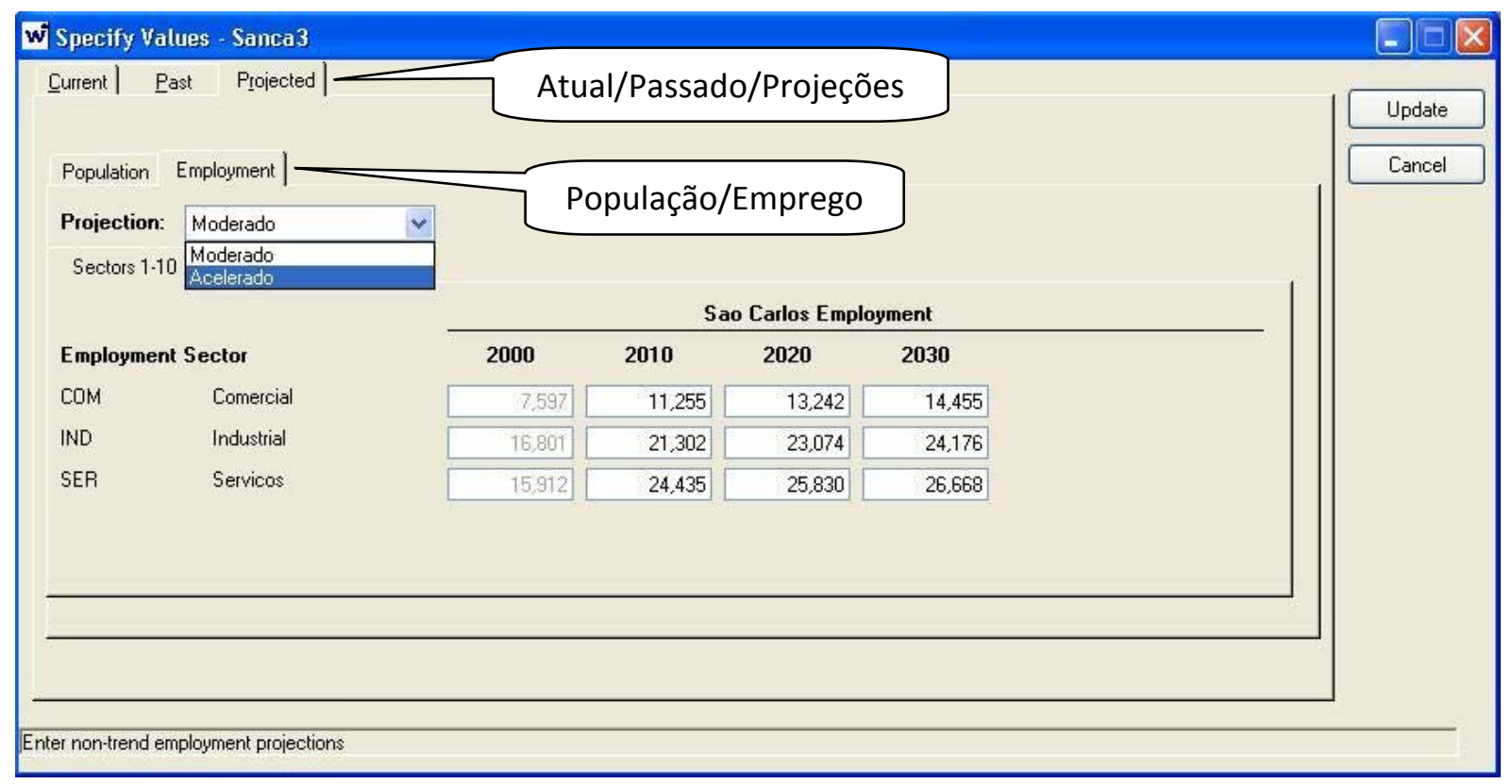

Figura 5.7 - What if? - ferramenta Projeções (Project / Values).

\section{$\underline{\text { 5.1.2.3 Demanda }}$}

Com base nos valores inseridos com a ferramenta Projeções e nas densidades iniciais de ocupação, utiliza-se a ferramenta Demanda (Figura 5.8) para definir cenários de desenvolvimento, selecionando as projeções demográficas a serem calculadas de acordo com as características de cada cenário. A ferramenta então calcula a quantidade de solo necessária para acomodar cada tipo de uso de acordo com seu crescimento durante o período. Há também opções de dividir os usos de acordo com os níveis de densidade, considerar taxas percentuais de lotes desocupados, entre outras características que variem ao longo do período que, porém, não foram utilizadas na aplicação. 


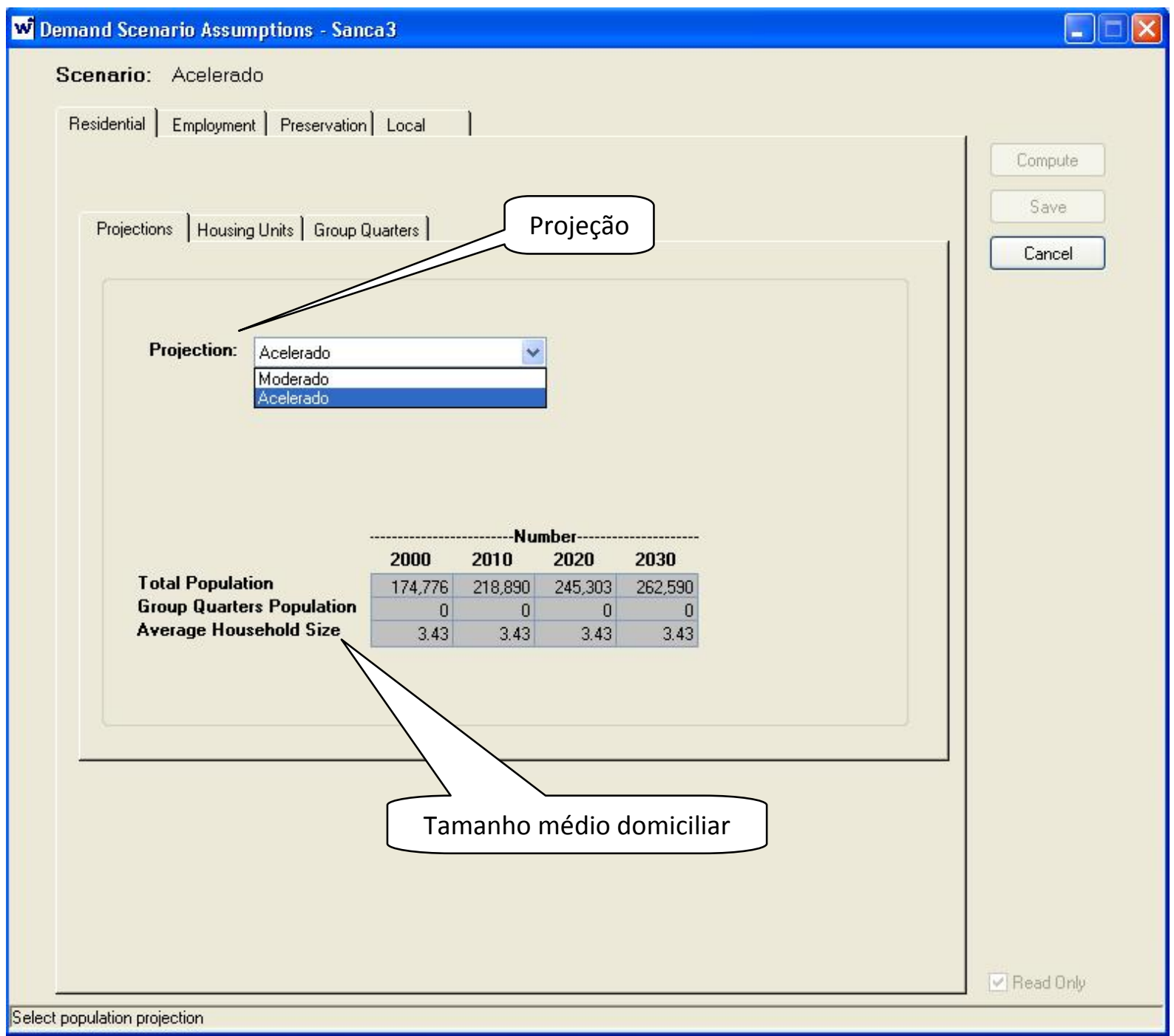

Figura 5.8 - What if? - ferramenta Demanda (Demand).

Essa ferramenta, em conjunto com a ferramenta Projeções, desempenha um papel importante no processo de planejamento aqui proposto. Caso haja futuras mudanças nas perspectivas de crescimento da cidade, implicando na criação de novos cenários de população ou emprego, serão essas ferramentas o novo ponto de partida. Entretanto, da forma como foi utilizada, a ferramenta se mostra relativamente simples e, somando-se o fato de que se mostrou dependente de procedimentos prévios em planilha eletrônica, apresenta pontos que podem ser aprimorados. 


\subsubsection{Alocação do Uso do Solo}

A ferramenta de Alocação do Uso do Solo (Figura 5.9) é a responsável por gerar os resultados propriamente ditos das projeções futuras de ocupação. Ela utiliza os dados gerados pelas ferramentas anteriores, selecionando-se os cenários que se deseja adotar, e processa em que sequência as novas áreas serão ocupadas, com base nas diretrizes definidas dentre as opções disponíveis. No estudo, foram definidas como diretriz principal as restrições de ocupação obtidas com a ferramenta Adequabilidade. Dessa forma, a ferramenta restringe as áreas ocupáveis e então processa as demais diretrizes. Como segunda diretriz foi definido o plano sequencial que representa o padrão de crescimento da cidade, gerado com as informações do Plano Diretor, onde a ordem prevista para ocupação foi representada através de camadas. Assim, a ferramenta processa a quantidade de solo ocupado em áreas ocupáveis até que a primeira camada seja preenchida completamente. Para o preenchimento da camada, na ausência de opções mais realistas, foi definida como terceira diretriz o padrão aleatório, que faz com que todas as áreas (cabíveis de ocupação) da camada sejam ocupadas aleatoriamente até seu preenchimento total. Após o preenchimento da primeira camada, tem-se a ocupação da segunda, e assim por diante, até que toda a demanda populacional e de empregos seja atendida com a quantidade necessária de solo, definida pela ferramenta Demanda.

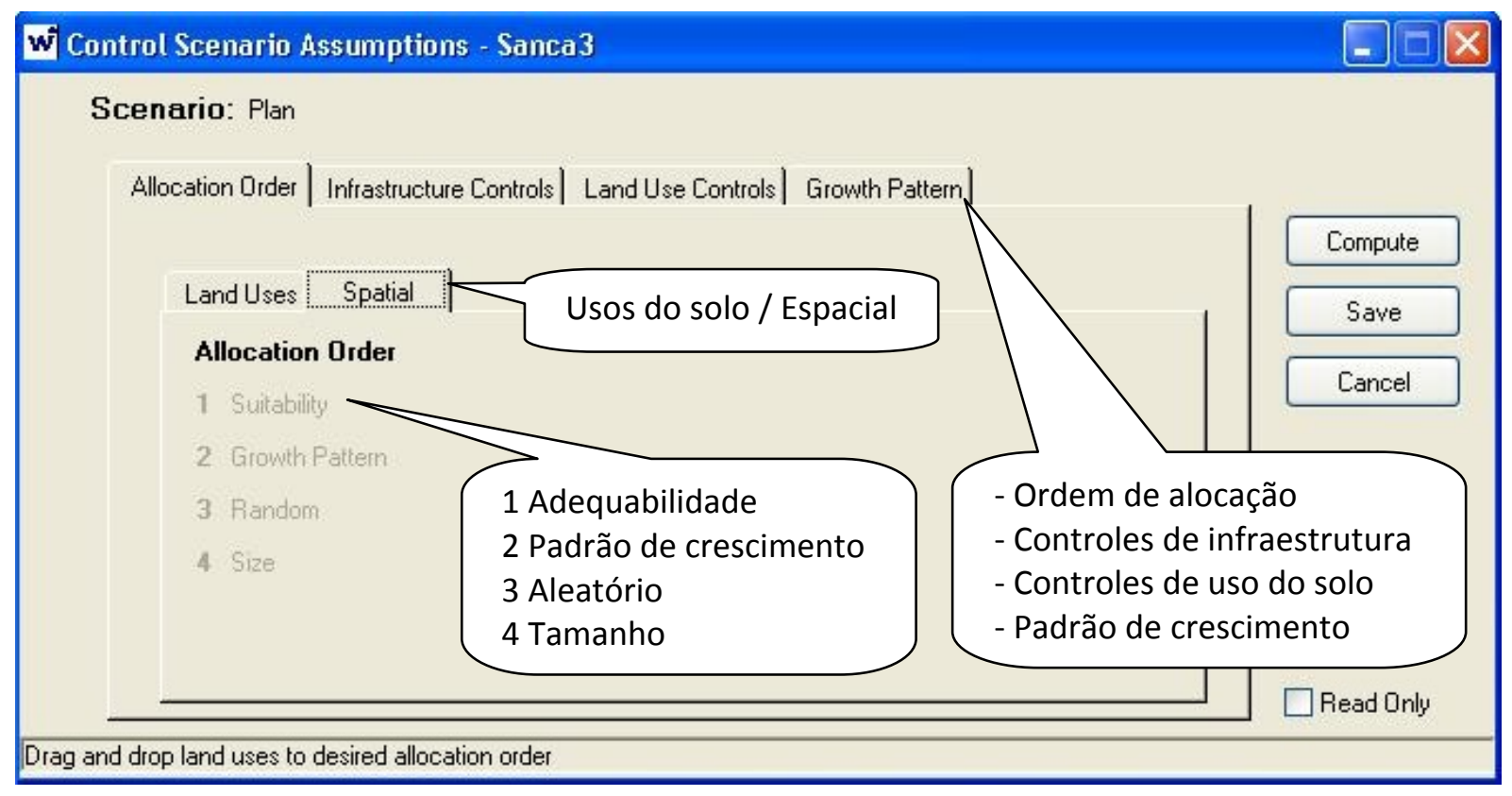

Figura 5.9 - What if? - ferramenta Alocação do Uso do Solo (Allocation). 
Esse processo de ocupação é executado de acordo com os valores de demanda definidos para cada intervalo do período de estudo, fazendo com que sejam geradas previsões de ocupação para cada um desses intervalos. Se, durante o processo, toda a área disponível para ocupação for preenchida e ainda assim a demanda total para o período considerado não tiver sido atendida, a ferramenta interromperá o processo e exibirá uma mensagem informando a lotação das áreas disponíveis. Nesse caso, uma ou mais medidas devem ser tomadas para que o processo de ocupação possa alocar toda a demanda de solo para o período considerado. Entre as medidas possíveis, alguns exemplos são: a ampliação da área de estudo, a redução das taxas de crescimento, a mudança de uma ou mais diretrizes de desenvolvimento, o aumento da densidade de ocupação, entre outros.

Realizada a alocação, a ferramenta contabiliza os números de habitantes e empregos por setor de atividade para cada área de contagem definida. No caso da aplicação, essas áreas foram definidas pelas Zonas de Análise de Tráfego nas quais a área de estudo foi dividida. Esse procedimento é importante, pois através desses números é que serão estimadas na etapa seguinte as viagens produzidas e atraídas dentro de cada uma dessas zonas. Dessa forma, as Zonas de Análise de Tráfego servirão de base para determinar a demanda por transporte equivalente a cada uma das situações de ocupação projetada.

A ferramenta de Alocação do Uso do Solo oferece ainda outras funcionalidades que não foram utilizadas na aplicação, como as opções de restringir a ocupação de acordo com a infraestrutura urbana construída e estimada, ou de acordo com possíveis leis de zoneamento. É, sem dúvida, uma das ferramentas mais importantes do modelo, já que é responsável pela primeira parte dos resultados necessários para o processo de planejamento aqui proposto. Levando em conta a metodologia utilizada, não seria possível estimar a demanda futura por transporte na cidade sem suas projeções futuras de uso do solo. Além disso, essas projeções por si só representam dados importantes para o planejamento estratégico da cidade.

Por sua característica de processar diversas restrições e diretrizes e contabilizar grande quantidade de dados simultaneamente, a ferramenta apresenta certo nível de complexidade, tornando-a um tanto delicada para um possível processo de adaptações. Porém, algumas funcionalidades se mostraram passíveis de otimização, como é o caso do processo de preenchimento da ocupação através 
de camadas, que exige um procedimento prévio em SIG (externo ao What if?) para gerar o mapa contendo tais camadas. Uma alternativa possível seria executar o processo de ocupação com base em um vetor de crescimento, que faria com que a ferramenta alocasse a ocupação obedecendo à direção apontada por esse vetor. Esse processo poderia substituir a utilização das camadas ou até mesmo ser utilizado em conjunto com as mesmas, servindo como alternativa para o padrão de ocupação aleatória.

Outra funcionalidade interessante, que tornaria o processo de ocupação mais realista, seria considerar a alocação através de aglomerações por tipo de uso, como loteamentos residenciais, centros comerciais ou parques industriais. Essas novas aglomerações poderiam ser dimensionadas com base nas aglomerações equivalentes já ocupadas no início do estudo ou utilizando possíveis planos de loteamento disponíveis. Esse procedimento, assim como a utilização de um vetor de crescimento, evitaria o padrão de ocupação esparso obtido na aplicação, o que para grandes áreas de expansão pode representar uma diferença significativa na futura demanda por transportes.

\subsubsection{Modelo sequencial de demanda por transportes}

Nessa etapa é executado um modelo específico para o planejamento de transportes, denominado modelo sequencial de demanda, ou modelo de quatro etapas. Esse modelo utiliza como dados de entrada as características da cidade presentes no Plano Diretor, já inseridas e preparadas com o uso do SIG, além dos resultados obtidos na etapa anterior, contendo as projeções futuras de ocupação e uso do solo. O modelo é executado para cada um dos cenários gerados na etapa anterior no qual se deseje avaliar a demanda equivalente por transporte. Para sua execução, foram utilizadas ferramentas do programa TransCAD, cobrindo três dos seus quatro passos, sendo que o terceiro passo, a escolha modal, foi resolvido apenas com a utilização de planilha eletrônica. Todas as ferramentas são acessadas através da interface principal do programa (Figura 5.3). A seguir, são apresentadas as ferramentas utilizadas para cada um dos passos. 


\subsubsection{Balanceamento de Vetores (Primeiro passo: geração de viagens)}

Para definir o número de viagens produzidas e atraídas no interior de cada Zona de Análise de Tráfego, foi considerado como hipótese que as viagens de ida ao trabalho representariam com precisão satisfatória o volume de viagens realizadas no pico da manhã. As viagens de trabalho foram classificadas como o principal motivo de viagens de acordo com a Pesquisa O/D realizada na cidade, e se mostram interessantes por sua característica de estarem concentradas no horário de pico mais congestionado. Essa situação de máximo congestionamento é desejada para prever os pontos críticos dos impactos provocados pelas viagens. Dessa forma, as viagens foram definidas com início em lotes residenciais e destino em lotes que comportam empregos. Ou seja, para cada Zona de Análise de Tráfego, o número de empregos representa o número de viagens destinadas a ela e, para o número de viagens que dela se originam, deve-se utilizar a população corrigida da zona. Essa correção é necessária, pois considerar a população total das zonas seria admitir que toda a população da cidade estaria simultaneamente realizando viagens de ida ao trabalho, o que não seria possível já que o número de empregos não seria suficiente. Por isso, a parcela da população que deve ser considerada no modelo deve ser igual ao número total de empregos, garantindo o equilíbrio entre o total de viagens iniciadas e concluídas.

Para essa correção, é então utilizada a ferramenta de Balanceamento de Vetores (Figura 5.10), que executa um procedimento matemático, corrigindo o vetor população com base no vetor empregos. É uma ferramenta simples, cujos procedimentos podem ser perfeitamente executados inclusive em planilha eletrônica, multiplicando-se os valores de população por uma taxa de redução equivalente à razão entre o número total de empregos e a população total. 


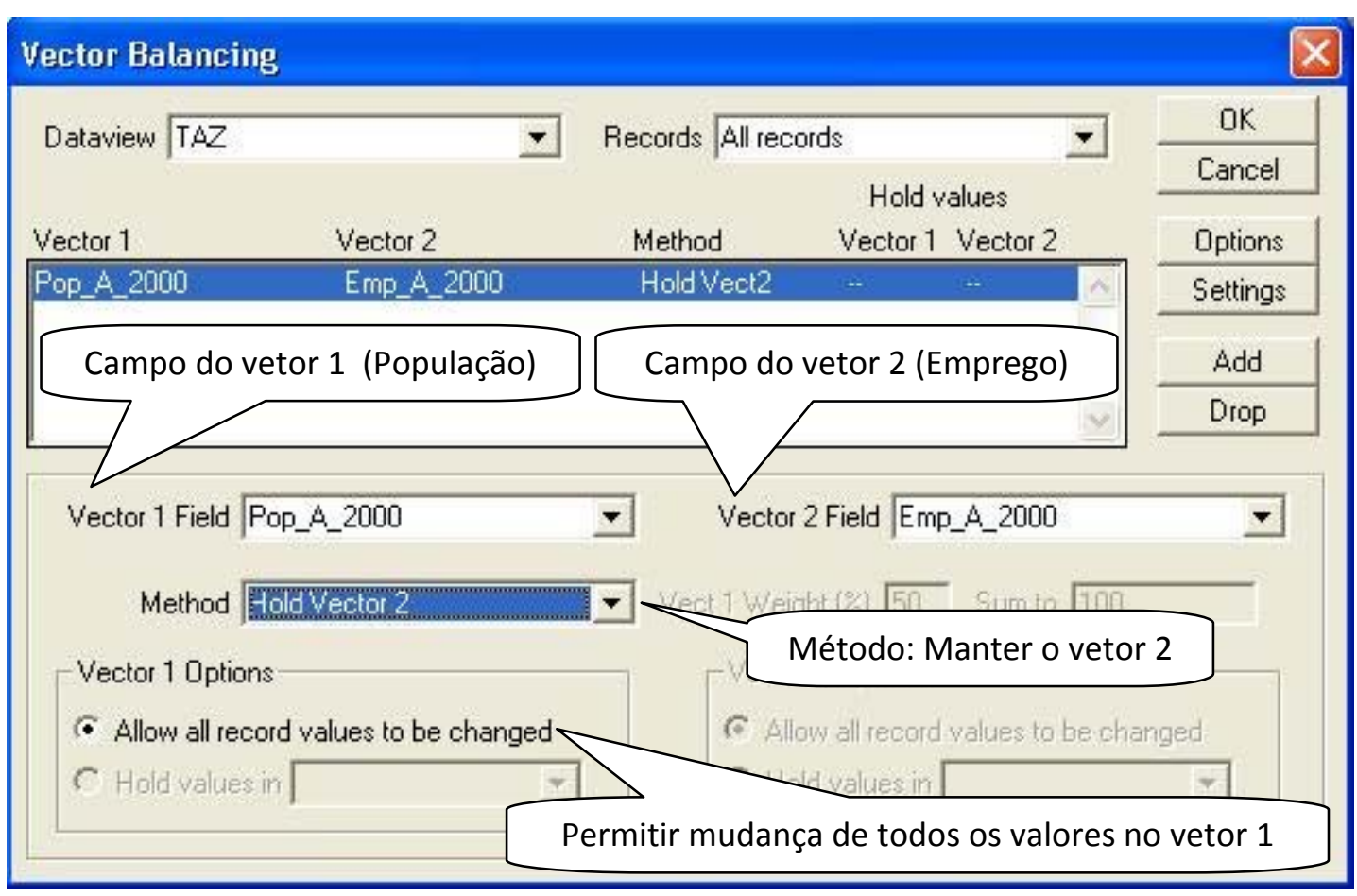

Figura 5.10 - TransCAD - ferramenta Balanceamento de Vetores (Planning / Balance).

\subsubsection{Modelo Gravitacional (Segundo passo: distribuição de viagens)}

Com o balanceamento dos vetores população e emprego, têm-se para cada Zona de Análise de Tráfego o total de viagens originadas e destinadas a ela. Para determinar a distribuição dessas viagens pelas zonas, tinham-se disponíveis, além do número de viagens, os seguintes dados: as distâncias entre os centróides das zonas, obtidas no SIG; as distâncias internas de cada zona, obtidas por uma equação matemática (SMEED, 1967); e uma constante gravitacional, num primeiro momento, calibrada para a distribuição de viagens na cidade de Araraquara (RODRIGUES DA SILVA, 1998), por sua proximidade e semelhança com São Carlos, e depois, calibrada a partir dos dados da Pesquisa O/D de São Carlos (item 3.2.4).

Com essas informações, fez-se uso da ferramenta Modelo Gravitacional (Figura 5.11), que oferece algumas opções de fatores de correção e tipos de atributo condicionantes para a distribuição das viagens. Para a aplicação, considerou-se apenas o fator do tipo inverso para todas as zonas (a constante gravitacional) e o atributo da distância, representando o custo de viagem. Para executar a ferramenta, foi necessário que as distâncias das zonas fossem armazenadas em forma de matriz e a constante gravitacional fosse inserida no campo designado para tal. Através de 
iterações, a ferramenta calcula a distribuição equivalente aos dados informados, gerando como resultado a matriz origem/destino. Essa matriz contém o número de viagens realizadas entre cada par de zonas da cidade, além do número de viagens internas de cada zona. A matriz origem/destino é um dado fundamental para o planejamento urbano e de transportes e, a partir dela, vários modelos podem ser executados.
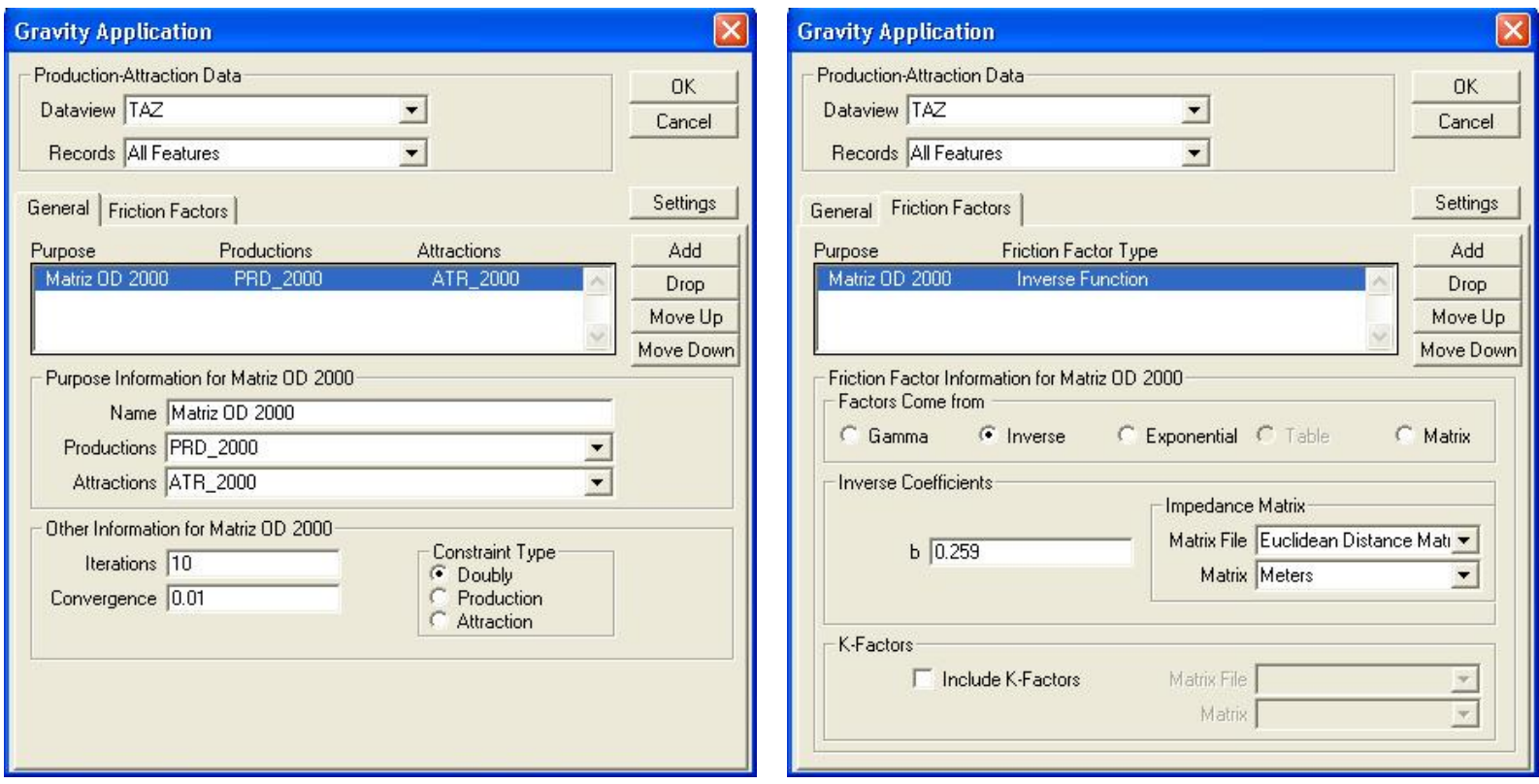

Figura 5.11 - TransCAD - ferramenta Modelo Gravitacional (Planning / Trip distribution / Gravity application).

A ferramenta apresenta certo grau de complexidade em função da grande quantidade de cálculos necessários, exigindo até mesmo um processo iterativo para obtenção dos resultados. Porém, como os cálculos são desvinculados da base geográfica do SIG, é possível a execução de procedimentos equivalentes em planilha eletrônica, conhecendo-se as equações matemáticas do modelo. Esse processo, entretanto, exige atividades trabalhosas no sentido de formular os procedimentos, o que também ocorre no processo de calibração executado com a ferramenta Calibração do Modelo Gravitacional (item 5.1.5.1).

\subsubsection{Método de divisão modal (Terceiro passo: escolha modal)}

Apesar da disponibilidade de ferramentas capazes de determinar a escolha dos modos de viagem pelos usuários do sistema, esse passo do modelo foi 
simplificado na aplicação. Essa simplificação se deu pela falta de um processo prévio de organização, seleção e modelação dos dados socioeconômicos levantados na Pesquisa O/D realizada na cidade, dada sua recente conclusão frente à realização desse trabalho.

Foi utilizado, portanto, um procedimento de divisão dos modos de viagem de acordo com a porcentagem geral de uso pelos entrevistados na pesquisa. Essa porcentagem foi calculada através de planilha eletrônica e considerada fixa para todas as zonas da cidade, multiplicando-se o total de viagens pelas parcelas correspondentes a cada modo. Essa não é uma hipótese muito realista, visto que é esperado que ocorra certa variação de uso dos modos nos diferentes bairros da cidade. Porém, considerando a baixa precisão necessária quanto ao número efetivo de viagens, já que são mais importantes as diferenças relativas provocadas pelo processo de crescimento, a hipótese foi considerada satisfatória. De acordo com esse procedimento, as matrizes origem/destino, com as viagens totais entre zonas, são divididas em matrizes equivalentes com as viagens para cada modo. Para a aplicação apresentada foram utilizadas apenas as matrizes com as viagens pelo modo ônibus.

Com o intuito de tornar o processo de escolha modal mais realista, é possível, através das ferramentas disponíveis ou mesmo de planilha eletrônica, definir um modelo de escolha individual baseado em fatores socioeconômicos. Esse modelo atribuiria, para cada fator, uma relação com a preferência do usuário por determinado modo de transporte. Dessa forma, através dos valores médios para cada Zona de Análise de Tráfego, o modelo seria capaz de definir o número de viagens realizadas em cada um dos modos considerados, para cada uma das zonas.

\subsubsection{Alocação Tudo ou Nada (Quarto passo: alocação de tráfego)}

Com as matrizes origem/destino contendo as viagens realizadas exclusivamente através do modo de transporte priorizado no estudo, é possível a execução do quarto e último passo do modelo de demanda. Para realizar a alocação de tráfego e finalmente obter os impactos da expansão urbana sobre o sistema de transporte público de São Carlos, fez-se uso da ferramenta de Alocação Tudo ou Nada (Figura 5.12). Além das matrizes origem/destino para cada cenário que se 
deseja avaliar, a ferramenta requer a localização geográfica dos centróides das Zonas de Análise de Tráfego e a rede de vias urbanas nas quais as viagens devem ser alocadas. É ainda requerido como parâmetro, especificar se a ferramenta, ao alocar as viagens, deve minimizar a distância ou o tempo de percurso. No caso da aplicação, as diferenças de velocidade nas vias não representavam um fator significativo no tempo das viagens, portanto foi definido como parâmetro minimizar as distâncias. Dessa forma, a ferramenta testa, para cada par de centróides, todas as possíveis rotas e seleciona aquela com a menor distância, alocando na rota selecionada o número de viagens entre aqueles dois pontos, de acordo com o valor especificado na matriz origem/destino. Fazendo isso para todos os pares de centróides, a ferramenta soma todas as viagens alocadas em cada via, representando assim o fluxo total de viagens pela cidade.

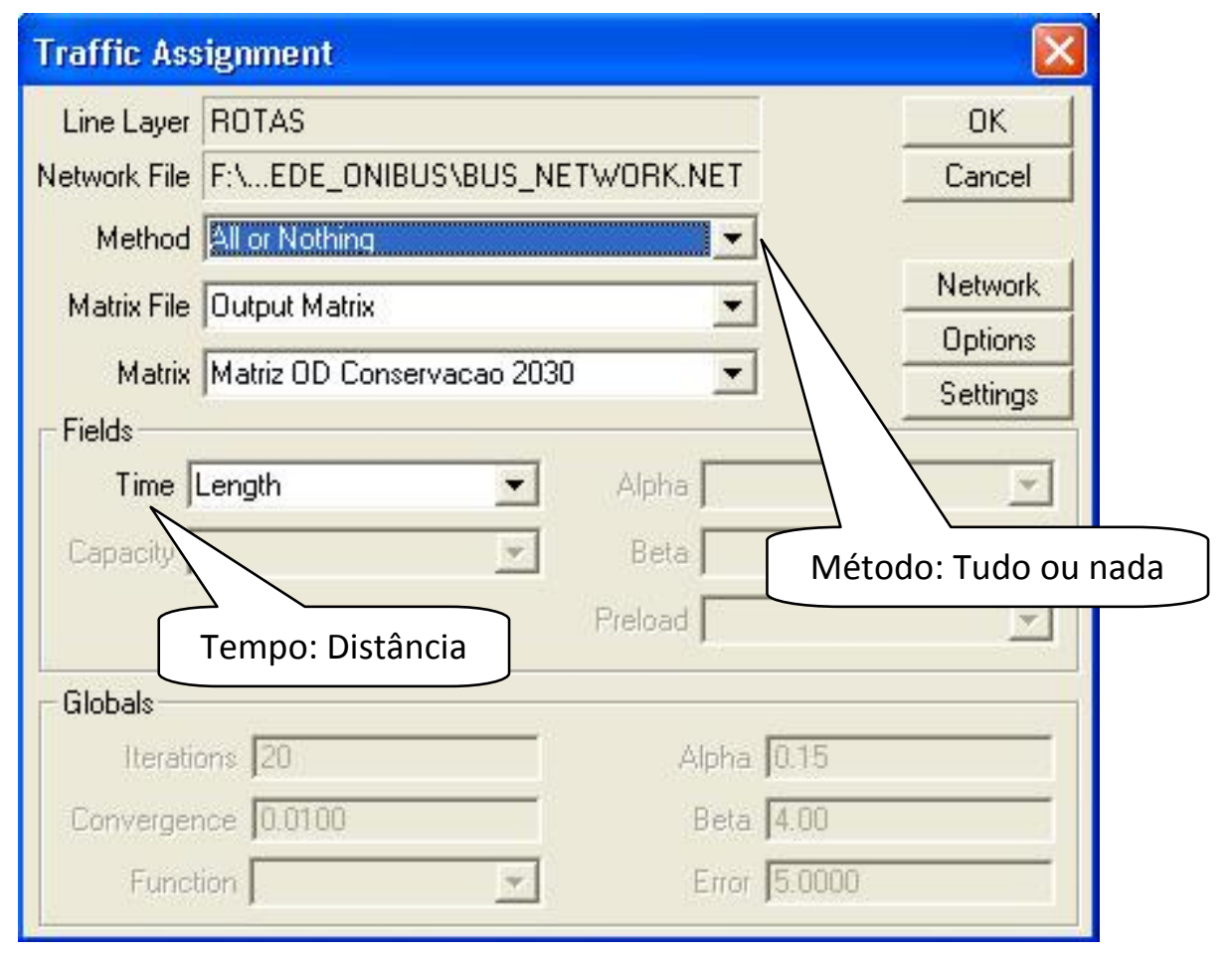

Figura 5.12 - TransCAD - ferramenta Alocação Tudo ou Nada (Planning / Traffic assignment - Method: All or nothing).

O método de alocação "tudo ou nada", apresentado no capítulo 2, foi escolhido para a aplicação por duas razões. Primeiramente, esse é o método mais simples de alocar as viagens a um sistema de vias, não exigindo o cálculo de suas capacidades, o que demandaria um trabalhoso processo. Vale lembrar que o número de viagens obtido nas matrizes origem/destino não representa o fluxo de 
veículos entre as zonas e sim o fluxo de pessoas. Para o cálculo do fluxo de veículos seria necessário acrescentar outro procedimento que consideraria as taxas de ocupação dos veículos nos horários de pico, o que pode variar em função de diversos fatores para cada região da cidade. A segunda razão que justifica a escolha do método é o fato de que a concentração de viagens em um menor número de vias representa mais visivelmente os impactos gerados sobre o sistema. Com esse procedimento, é possível verificar quais caminhos os usuários de fato gostariam de tomar se houvesse capacidade suficiente. E de posse das rotas mais procuradas, é possível repensar o sistema, avaliando a necessidade de ampliação da capacidade das vias mais congestionadas, verificando a distribuição e integração das rotas e estudando a implantação de novas vias. Com esses estudos, diferentes alternativas podem ser propostas para direcionar os fluxos de viagem de maneira satisfatória.

Apesar de executar procedimentos simples, a ferramenta apresenta certa complexidade, pois, além de processar e acumular uma grande quantidade de dados, ela está vinculada às informações geográficas de inúmeros elementos. Mostra-se uma ferramenta difícil do ponto de vista de possíveis alterações ou otimizações, porém, para a aplicação, mostrou-se perfeitamente satisfatória, atendendo aos procedimentos e resultados associados ao quarto passo do modelo de demanda.

\subsubsection{Visualização e análise dos resultados}

Depois de obtidos os resultados, através das ferramentas apresentadas nas etapas anteriores, tem-se a importante etapa de visualização e análise dessas informações. A escolha de ferramentas e métodos adequados para a apresentação dos resultados é fundamental, pois define a forma como esses dados são enfim interpretados. Ambos os programas utilizados na aplicação possuem ferramentas de visualização, porém, em relação ao What if?, o TransCAD possui um ambiente SIG mais elaborado. Isso justifica sua utilização para visualização e análise dos resultados tanto da etapa de projeção de uso do solo quanto para a demanda por transporte.

Dentre as ferramentas disponíveis, tem-se como função básica a criação de mapas temáticos, classificando e organizando os dados a serem apresentados. Apesar da possibilidade da apresentação numérica dos resultados, ou da criação de 
gráficos que ilustrem o comportamento e a tendência desses dados, a visualização através de mapas se mostra uma forma mais eficiente e esclarecedora. Essa forma de apresentação permite uma boa compreensão das informações através de análises visuais simples, facilitando a avaliação dos impactos por aqueles que não possuem conhecimentos técnicos específicos. É possível, se necessário, utilizar-se de mapas que exibam também informações gráficas, como barras ou setores, ou até informações numéricas, normalmente divididas por zonas de análise.

Com as ferramentas disponíveis e os dados obtidos, diversas análises podem ser realizadas nessa etapa. Para cada tipo de análise que se deseja fazer, deve-se escolher a ferramenta que melhor se adapte aos objetivos em questão. Com base no modelo proposto, são apresentadas as ferramentas e análises básicas que têm como função servir de apoio para futuros estudos e direcionar análises mais específicas. De acordo com os objetivos que possam surgir após as análises aqui apresentadas, outros tipos de análises, embora não citadas, são perfeitamente possíveis, por exemplo, com as demais ferramentas presentes no TransCAD. São descritas a seguir as ferramentas utilizadas na aplicação e suas características.

\subsubsection{Mapa Temático com Classificação por Cores}

Para a apresentação da primeira parte dos resultados da aplicação, as projeções de ocupação e uso do solo, foi utilizada a ferramenta de Mapa Temático com Classificação por Cores (Figura 5.13). Essa ferramenta gera o tipo mais básico e mais utilizado de mapa temático, onde todas as áreas do mapa são divididas em categorias de acordo com seus respectivos valores para um atributo definido. Para cada uma dessas categorias são definidos um nome e uma cor, de forma que, ao visualizar-se o mapa, seja fácil identificar quais áreas pertencem a cada categoria. Para facilitar essa identificação, normalmente faz-se o uso de legendas. As categorias podem representar intervalos em uma escala de valores, parâmetros de avaliação predefinidos (como "sim" e "não", ou "bom", "médio" e "ruim") ou simplesmente cada uma das classificações nomeadas para o atributo. 


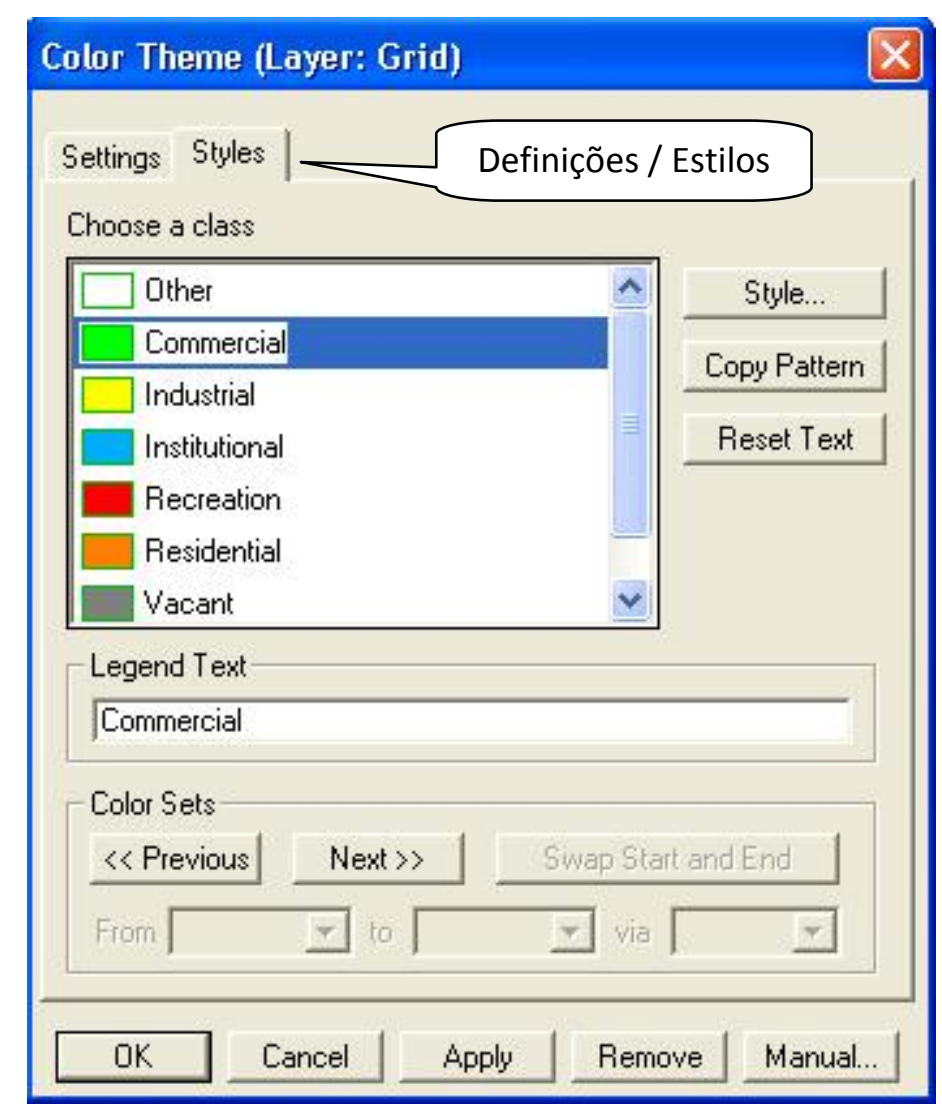

Figura 5.13 - TransCAD - ferramenta Mapa Temático com Classificação por Cores (Map / Color theme).

No caso das projeções de ocupação e uso do solo, cada um dos usos considerados foi associado a uma categoria representada por uma cor. Com um conjunto bem heterogêneo de cores, os mapas gerados permitem uma fácil visualização dos usos do solo para cada cenário gerado. Dessa forma, foi possível analisar visualmente a magnitude da expansão urbana estimada, tanto em termos de áreas ocupadas quanto pela localização e distribuição dos diferentes usos. Para essa análise é fundamental a observação conjunta dos mapas de início e fim do período de estudo.

Essa é uma ferramenta clássica de SIG que permite diversas aplicações. Foi utilizada inclusive para a apresentação dos mapas com os dados iniciais da cidade que definiram as diretrizes de desenvolvimento para a aplicação (item 4.1). Uma funcionalidade importante é a capacidade de compartilhar os esquemas de cores entre diferentes arquivos e mapas. Devido à necessidade de visualização conjunta dos resultados para que seja possível avaliar os impactos entre as situações iniciais e finais, o sistema de cores deve manter-se idêntico para todos os mapas. Esse requisito faria com que as mesmas cores precisassem ser selecionadas repetidas 
vezes, representando um ponto de ineficiência, além de dar margem a possíveis enganos na seleção de cores, prejudicando os resultados. Porém, utilizando as opções de salvar e carregar padrões de cores, esses problemas são evitados.

\subsubsection{Mapa Temático com Classificação por Objetos em Escala}

Para a apresentação dos resultados finais da aplicação, a demanda estimada por viagens, foi utilizado um procedimento mais específico, através da ferramenta de Mapa Temático com Classificação por Objetos em Escala (Figura 5.14). Seria possível utilizar a classificação por cores citada anteriormente, porém haveria a necessidade da definição de intervalos, dividindo o número de viagens em categorias. A classificação através da representação em escala não necessita de categorias, exibindo as informações de forma mais detalhada, sem prejudicar a facilidade de interpretação.

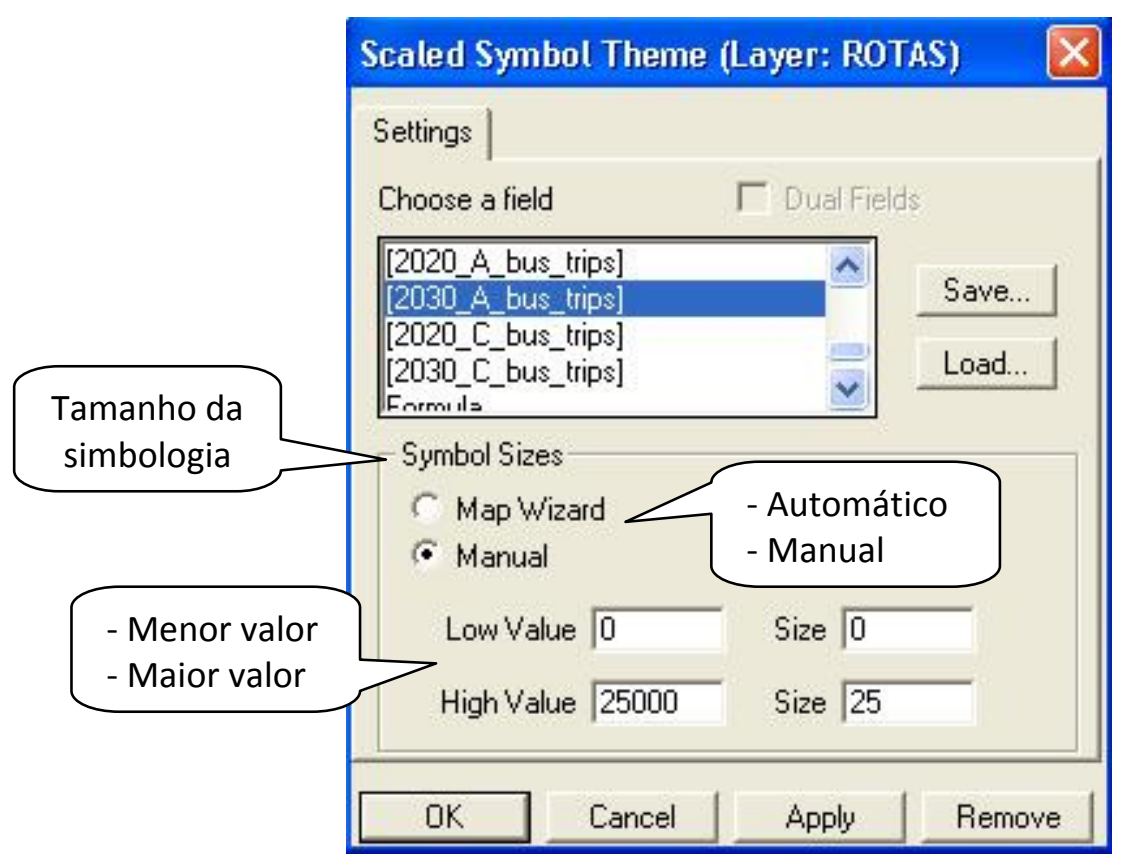

Figura 5.14 - TransCAD - ferramenta Mapa Temático com Classificação por Objetos em Escala (Map / Scaled-symbol theme).

A ferramenta gera, para cada elemento a ser classificado, um objeto cujo tamanho representa o valor associado ao atributo em questão, de acordo com uma escala. Essa escala, por padrão, é definida automaticamente pela ferramenta, de acordo com os valores mínimos e máximos do atributo e tamanhos equivalentes dos objetos considerados confortáveis para visualização. Porém, existe a possibilidade 
de se definir a escala manualmente, inserindo, para os valores do atributo, os tamanhos equivalentes para os objetos de visualização.

No caso da aplicação, como os elementos de classificação são as vias da rede considerada, ou seja, elementos lineares, os objetos de visualização são representados através de linhas sobrepostas às vias. Essas linhas apresentam espessuras variáveis de acordo com a escala definida para o atributo "Número de viagens". Dessa forma, olhando-se o mapa é possível saber quais as vias de maior ou menor demanda por viagens e avaliar a proporção entre essas demandas, o que representa um fator importante para o processo de planejamento da cidade.

Assim como no caso da outra ferramenta de mapa temático, citada anteriormente, os mapas de demanda por viagens também necessitam ser visualizados conjuntamente. Essa condição faz com que os mapas precisem ser gerados com os objetos de visualização obedecendo a uma mesma escala. Apesar de ser um procedimento aparentemente óbvio, nem sempre esses cuidados são tomados, como pode ser observado em Han (2008), onde os fluxos iniciais e finais são apresentados em escalas diferentes.

Diante de tal necessidade, destaca-se um aspecto importante da ferramenta, onde é possível salvar e carregar padrões definidos de escala, permitindo o uso de escalas compatíveis em diferentes arquivos e mapas. Entretanto, as escalas são limitadas pelos valores designados como mínimo e máximo, fazendo com que, ao utilizar um padrão salvo para outro mapa, a nova escala fique limitada à primeira. Ou seja, se o segundo mapa possuir valores além dos limites da escala salva para o primeiro mapa, ao carregar essa escala para o segundo mapa, os valores além dos limites não aparecerão no mapa temático. Esse problema poderia ser resolvido se a ferramenta possuísse a funcionalidade de definir escalas através de uma proporção fixa sem a exigência de valores limite.

Seria interessante também a possibilidade de definir escalas simultaneamente para dois ou mais mapas, já que muitas vezes uma determinada escala, adequada para um mapa, quando aplicada em outro, resulta em objetos muito pequenos ou muito grandes. Isso exige refazer a escala do primeiro mapa, testando-a novamente no segundo e assim sucessivamente até que ambos os mapas possuam visualizações adequadas. 


\subsubsection{Calibração}

Outro processo importante de qualquer modelo são as atividades de calibração, seja dos valores gerados, das hipóteses adotadas, ou dos fatores e constantes utilizados. Esse processo tem como função adequar os modelos para que representem o mais fielmente possível a realidade simulada, sendo normalmente realizado após a obtenção de resultados, ou em paralelo aos procedimentos principais do modelo.

No primeiro caso, os resultados obtidos são comparados com dados reais, de mesma natureza, normalmente coletados em forma de amostras ou unidades de controle. Na aplicação realizada, não foram executadas calibrações desse tipo, já que os resultados não exigiam um nível alto de precisão. Apesar disso, essas atividades se mostram perfeitamente possíveis em estudos futuros na cidade. Alguns exemplos seriam a comparação dos valores demográficos estimados com os futuros dados censitários (total e por zona), ou a comparação do número de viagens estimadas com o total de viagens de ônibus realizadas durante o horário de pico (total, entre zonas ou em vias de controle).

Já no segundo caso, executam-se testes internos, adotando parâmetros a fim de verificar o comportamento dos dados e identificar possíveis erros, ou ainda são extraídos fatores e constantes calibrados a partir de dados reais previamente coletados, como foi feito na aplicação. Para isso foi utilizada uma ferramenta de calibração presente no programa TransCAD, que é apresentada a seguir.

\subsubsection{Calibração do Modelo Gravitacional}

Como foi dito anteriormente, a ferramenta Modelo Gravitacional (item 5.1.2.3) utiliza para o processo de distribuição das viagens uma constante gravitacional, sendo que na aplicação foram utilizadas constantes gravitacionais de potência inversa, de acordo com o método de formulação utilizado. A primeira constante utilizada foi obtida de estudos anteriores, realizados na cidade de Araraquara (RODRIGUES DA SILVA, 1998), portanto já se obteve o valor da constante previamente calibrado. Num segundo momento, foram reunidos os dados da Pesquisa O/D de São Carlos para que se pudesse realizar uma nova calibração da constante, representando, assim, de forma mais adequada o comportamento das viagens estudadas. Essa calibração foi executada a partir da ferramenta Calibração 
do Modelo Gravitacional (Figura 5.15). A ferramenta executa o procedimento contrário ao executado na ferramenta Modelo Gravitacional, onde é gerada a matriz de viagens a partir de uma constante gravitacional. Aqui, a partir de uma matriz de viagens, é gerada uma constante gravitacional equivalente. Essa matriz, por sua vez, foi previamente gerada com os dados de viagens coletados por amostragem, durante a Pesquisa O/D. Os dados foram filtrados para que fossem contabilizadas apenas as viagens realizadas pelo modo ônibus e pelo motivo trabalho, representando o mesmo tipo de viagens utilizado no modelo.

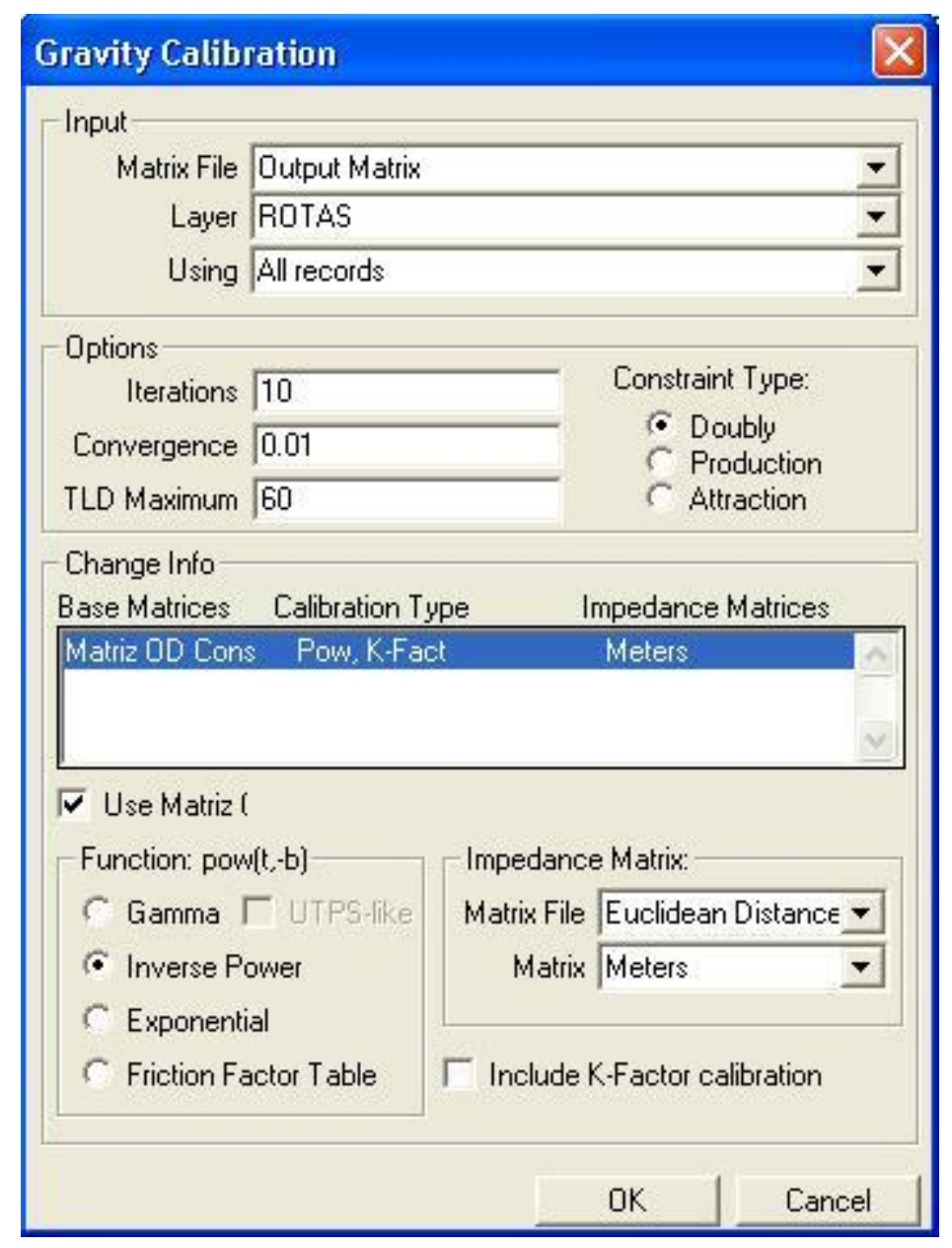

Figura 5.15 - TransCAD - ferramenta Calibração do Modelo Gravitacional (Planning / Trip distribution / Gravity calibration).

Assim como na outra ferramenta, é também aqui exigida a matriz com as distâncias entre os centróides das zonas, que permanece inalterada. Existe a possibilidade de utilizar a opção de calibração do Fator K, porém esse procedimento 
não foi utilizado na aplicação (para mais informações sobre o uso do Fator K, ver Ortúzar e Willumsen, 2006).

A ferramenta se mostrou extremamente útil na determinação da constante gravitacional e apresentou ótimo funcionamento em conjunto com a ferramenta Modelo Gravitacional, dada sua mesma interface e semelhança de procedimentos. Assim como na outra ferramenta, também houve a execução de processos iterativos, mostrando o mesmo grau de complexidade, o que acentua o nível de trabalho a ser exigido no caso da tentativa de execução dos procedimentos da ferramenta em planilha eletrônica.

\subsubsection{Ferramentas de suporte}

Durante todo o processo de execução da aplicação, diversas ferramentas foram utilizadas como elementos principais para o cumprimento de cada uma de suas etapas e subetapas. Porém, para que todos os dados do projeto pudessem ser adequadamente interpretados e trabalhados, foram necessárias algumas ferramentas que serviram como suporte para as principais. Muitas delas foram classificadas apenas como parte do ambiente SIG, porém algumas ferramentas específicas merecem destaque.

\subsubsection{Planilha Eletrônica}

A Planilha Eletrônica é a ferramenta de base para qualquer tipo de análise numérica. Suas funcionalidades abrangem desde as operações simples de uma calculadora até programas completos desenvolvidos através de sua interface. Seu principal uso no estudo foi complementar as demais ferramentas quando elas não se mostravam suficientes para lidar com as necessidades do modelo. Foi bastante utilizada para organizar os dados demográficos e estimar as taxas de crescimento através de gráficos e linhas de tendência, assim como para organizar e trabalhar os dados da Pesquisa O/D.

Apesar da interface SIG do TransCAD apresentar algumas funcionalidades típicas de Planilha Eletrônica, como a utilização de fórmulas e fatores condicionais na manipulação dos dados, essas funcionalidades ficam mais restritas aos arquivos geográficos e não são tão abrangentes quanto as funcionalidades encontradas em um programa específico de Planilha Eletrônica. E como a disponibilidade de 
programas desse tipo é grande, incluindo alguns gratuitos, não há motivos para dispensar o recurso. $\mathrm{Na}$ indisponibilidade dos programas apresentados nesse trabalho, muitas das ferramentas poderiam ser adaptadas em Planilha Eletrônica, dado seu nível moderado de complexidade e sua forma de tratamento dos dados. Porém como já foi dito anteriormente, seria bem mais difícil o desenvolvimento do modelo proposto sem a utilização de um SIG.

\subsubsection{Edição Matricial}

$\mathrm{Na}$ execução de algumas etapas, foram utilizadas ferramentas que trabalham com dados em forma de matrizes. Para manipular esses dados, o TransCAD conta com um conjunto de ferramentas de suporte para arquivos de matriz. Entre essas ferramentas, além de organizar e armazenar os dados em arquivos específicos para matrizes, é possível realizar procedimentos de edição, preenchimento e consulta das matrizes armazenadas. Esses procedimentos foram extremamente úteis na aplicação, principalmente por estarem incluídos junto à interface do sistema, facilitando bastante as etapas que dependem de matrizes. Esse recurso apresentou, porém, algumas restrições, principalmente no que diz respeito à compatibilidade com arquivos de Planilha Eletrônica, que se mostram um importante recurso no armazenamento de dados, por se tratar de um meio padronizado. Entretanto, essas restrições já estão sendo revistas nas versões mais recentes do programa TransCAD.

Outras ferramentas, por sua vez, realizam procedimentos com os dados geográficos e produzem seus resultados através de arquivos de matriz. Esse é o caso da ferramenta de medição das distâncias entre elementos de ponto, utilizada para medir as distâncias entre centróides das Zonas de Análise de Tráfego. De maneira geral, o conjunto de ferramentas de Edição Matricial mostra uma das vantagens da utilização de um programa com ferramentas integradas. De outra forma, seria necessário editar as matrizes separadamente, o que poderia ser feito também através de Planilha Eletrônica, mas certamente representaria um ponto de ineficiência do processo de execução do modelo. 


\subsubsection{Sistema de Redes Viárias}

Durante as etapas finais do modelo, foi utilizado um arquivo geográfico com as vias da cidade (item 3.2.5) para representar os fluxos simulados de viagens. Entretanto, a ferramenta Alocação Tudo ou Nada (item 5.1.3.4), assim como as demais ferramentas de alocação de fluxo de viagens não utilizadas na aplicação, exige, além desse arquivo básico de SIG com o cadastro de elementos lineares, a utilização de um arquivo de rede. Esse tipo de arquivo considera os elementos lineares não apenas como objetos isolados, mas sim conectando os elementos uns aos outros e criando, dessa forma, um Sistema de Redes Viárias que permite ao programa interpretar os atributos dos elementos conjuntamente. Além desse princípio básico do recurso, o TransCAD oferece diversas ferramentas para trabalhar com as redes. É nesse setor do programa que estão inseridas as principais ferramentas voltadas a procedimentos logísticos. Porém o modelo aqui proposto não utiliza esse tipo de abordagem. Para a aplicação, foi utilizado apenas o recurso de calcular as distâncias das rotas de viagem a partir da somatória das distâncias dos diversos elementos lineares (as vias) conectados através da rede ao longo do caminho mais curto. Essa tarefa é executada pela ferramenta Alocação Tudo ou Nada, como descrito no item 5.1.3.4.

Assim como no recurso de Edição Matricial, o Sistema de Redes Viárias se mostra fundamental para a execução do modelo, tendo como principal vantagem o fato de já estar inserido no programa, permitindo assim o funcionamento da ferramenta de alocação de viagens. De outra forma, seria necessário que todas as funcionalidades utilizadas pela ferramenta de alocação que foram desempenhadas pelo Sistema de Redes Viárias fossem inseridas junto à ferramenta de alocação, o que tornaria essa ferramenta ainda mais complexa.

\subsection{Os programas computacionais}

As ferramentas computacionais necessárias para a execução das diversas atividades envolvidas no processo de planejamento são reunidas e disponibilizadas através de programas computacionais. Esses programas, normalmente baseados em interfaces SIG, possuem ferramentas previamente desenvolvidas e testadas de acordo com o enfoque definido dentro das atividades de planejamento urbano que justifiquem um processo de sistematização. Conforme mencionado no capítulo 2, 
existe hoje uma escassez de programas voltados especificamente para as características de planejamento dos países em desenvolvimento. Isso faz com que muitas vezes seja necessária a utilização de programas mais abrangentes e complexos, além da necessidade de se usar mais de um programa para atender a todos os requisitos do modelo empregado. Por outro lado, muitas das ferramentas disponíveis nesses programas acabam sendo não utilizadas.

\subsubsection{TransCAD}

Para a execução do modelo proposto, foi utilizado o programa TransCAD, que trabalha num ambiente SIG-T. Dentre as ferramentas disponíveis no programa, há suporte para a maioria dos modelos e métodos apresentados no capítulo 2, sendo perfeitamente possível a execução dos quatro passos do modelo sequencial de demanda, uma vez que estejam disponíveis os dados e conhecimentos específicos necessários. Em termos de capacidade de processamento e diversidade de ferramentas, o TransCAD se mostra um programa capaz de lidar com as mais variadas atividades do planejamento logístico e de transportes. Entre ferramentas específicas e a capacidade abrangente e flexível de manipulação de dados geográficos, o programa apresenta diversas alternativas de solução para cada tipo de problema. É sem dúvida um dos programas mais utilizados atualmente para aplicações como as aqui apresentadas, dentre muitas outras. Inclusive, devido à sua crescente credibilidade e à abrangência de suas ferramentas, tem sido cada vez mais utilizado mesmo em cidades médias e até pequenas, substituindo modelos mais simplificados (HAN et al., 2007).

Por outro lado, exatamente por sua grande abrangência e complexidade, o TransCAD exige um nível consideravelmente alto de investimento, tanto do ponto de vista financeiro, quanto da capacitação necessária para a adequada utilização do programa (SCHRANK, 2004). A começar por sua interface principal (Figura 5.3), é necessária certa prática para localizar com rapidez os caminhos para execução das ferramentas, em meio a uma grande quantidade de opções. Além disso, também é necessária prática para lidar com as diversas extensões de arquivos utilizados pelo programa, assim como seu sistema de referência e armazenamento de dados. Devido à abordagem específica do modelo aqui apresentado, muitas das 
ferramentas do programa se mostraram totalmente dispensáveis para essa aplicação, o que representa um investimento não completamente aproveitado.

Características como essas tornam o TransCAD menos atrativo para utilização em cidades pequenas ou médias. Para cidades grandes, agências metropolitanas ou de abrangência estadual e nacional, o programa já se mostra bem mais atrativo. Um exemplo disso foi a sua utilização no Plano Nacional de Logística e Transportes - PNLT (http://www.transportes.gov.br/pnlt/index.htm), onde foram executados procedimentos semelhantes aos apresentados na aplicação do capítulo 4, através de um modelo sequencial de demanda. Além disso, o programa se mostra igualmente atrativo para utilização por empresas de consultoria ou atuantes no mercado logístico e de transportes, por sua maior gama de atuação.

Levando-se em conta a grande diversidade de ferramentas contidas no TransCAD, uma estratégia interessante para futuras versões seria a subdivisão do programa de acordo com públicos mais específicos. Versões como "TransCAD Developing Countries", para países em desenvolvimento, ou "TransCAD Strategic Planning", para o planejamento estratégico, poderiam oferecer ferramentas mais direcionadas, além de interfaces mais intuitivas e personalizadas, tornando o programa mais atrativo. Uma estratégia semelhante é utilizada pela empresa Autodesk (http://www.autodesk.com.br/produtos), subdividindo seus programas de desenvolvimento de projetos gráficos de acordo com as áreas de aplicação, como as engenharias civil e mecânica, arquitetura, entre outros.

Entretanto, mesmo com essa grande quantidade de ferramentas, algumas importantes etapas ainda precisam ser executadas através de ferramentas externas. No caso das atividades de planilha eletrônica, se essa interface do programa fosse mais elaborada, poderia reduzir ou até eliminar a necessidade de utilizar um programa específico para esse fim. Essa preocupação, inclusive, tende a aumentar nas próximas versões do programa. De maneira geral, apesar dos pontos negativos, - TransCAD se mostra uma solução rápida e eficiente para o processo de planejamento urbano, mesmo em cidades médias. Ele exige apenas um alto nível de investimento inicial, que se justifica, no entanto, em nível de resultados a médio e longo prazo. 


\subsubsection{What if?}

Para complementar o conjunto de ferramentas necessárias para a execução do modelo proposto, foi utilizado o programa What if?. Diferente do TransCAD, o What if? apresenta uma abordagem mais específica e direta, com todas as suas ferramentas fazendo parte de um mesmo objetivo comum de gerar projeções futuras de ocupação e uso do solo. Existe a possibilidade de gerar apenas resultados intermediários, como mapas de adequabilidade do solo ou quantidades de solo necessárias para ocupação, dispensando o uso de algumas ferramentas. Porém a utilização mais importante do programa é certamente a geração de mapas e dados geográficos representando cenários futuros, de acordo com as hipóteses definidas.

O What if?, assim como o TransCAD, também utiliza uma interface SIG, porém bem mais simplificada. Não há, por exemplo, a opção de livre manuseio dos dados, sendo estes gerados apenas de forma automática pelo processamento realizado pelas ferramentas. Os dados são inicialmente especificados no programa, de forma que possam ser interpretados automaticamente, dispensando a preocupação com fatores operacionais internos, como códigos de variáveis ou a localização de dados nas colunas correspondentes dos arquivos geográficos. Esse mecanismo contribui para a execução dos procedimentos do modelo de forma mais simples e intuitiva. Contudo, é preciso destacar a importância da verificação e conferência dos dados processados de modo automático, a fim de evitar possíveis erros.

As ferramentas, por sua vez, são poucas e bem distribuídas, facilitando a execução das etapas do programa numa estrutura sequencial. O padrão sequencial também facilita a execução das ferramentas, tornando-a mais organizada. Nesse sentido, seria mais conveniente que a ferramenta Projeções (item 5.1.2.2) estivesse incluída na ferramenta Demanda (item 5.1.2.3), ou que, pelo menos, tivesse sido alocada na sequência natural de execução, entre as ferramentas Adequabilidade (item 5.1.2.1) e Demanda. Além disso, seria igualmente interessante que a ferramenta "What if? Setup" (item 5.1.1.2), externa à interface principal do programa, fosse incluída junto às demais ferramentas, no papel de primeira ferramenta da sequência de execução, na interface do programa (Figura 5.5).

Como consequência dessa estrutura mais simplificada e intuitiva, o What if? possui pouca necessidade de treinamento e capacitação dos profissionais, no 
sentido de utilizar o programa. Da mesma forma, por ser um programa de abrangência mais específica, exige um menor nível de investimento inicial, em relação a programas mais abrangentes. Essas características sem dúvida tornam o programa mais atrativo para utilização em cidades de países em desenvolvimento. Porém, essas limitações fazem do programa apenas uma ferramenta preliminar para o processo de planejamento, tornando necessária a utilização de outros programas que trabalhem a partir de seus resultados. Uma interface SIG mais elaborada e algumas ferramentas adicionais poderiam diminuir consideravelmente esse aspecto.

Outra característica do What if? é a sua disponibilização relativamente recente no mercado, visto que a empresa desenvolvedora do programa foi fundada em 1996. O programa necessita ainda de alguns aprimoramentos para solucionar problemas principalmente de compatibilidade, dada sua natureza de utilização em conjunto com outros programas. Nesse sentido, a inclusão de ferramentas mais abrangentes poderia tornar o programa menos dependente de outros programas, diminuindo as necessidades de compatibilidade. Apesar disso, uma grande vantagem foi aproveitada na aplicação do capítulo 4, pois foi possível contar com a presença direta dos desenvolvedores do programa, fornecendo um valioso suporte para a utilização de suas ferramentas.

\subsubsection{Outros programas}

Na realização do estudo apresentado, o modelo proposto foi satisfatoriamente executado apenas com a utilização dos programas TransCAD e What if?, além de alguns procedimentos auxiliares executados externamente em planilha eletrônica. Para essas atividades de planilha eletrônica existem diversas opções de programas disponíveis e igualmente capazes, incluindo programas gratuitos, fazendo com que a execução desses procedimentos auxiliares não apresente maiores problemas. Quanto à possibilidade da utilização de outros programas, em alternativa aos utilizados na aplicação, para futuros estudos ou aplicações do modelo proposto, podem ser feitas algumas observações.

Levando em consideração as peculiaridades e restrições do processo de planejamento encontradas nos países em desenvolvimento, deve-se considerar a utilização do conjunto de programas que melhor se adapte aos objetivos almejados, reduzindo o nível de investimento e os recursos adquiridos sem necessidade. 
Independente dos modelos e abordagens que se pretenda utilizar, uma ferramenta imprescindível para o processo de planejamento urbano, como já mencionado anteriormente, é o SIG (item 5.1.1.1). Portanto, durante o processo de escolha de programas que ofereçam suporte para as atividades de planejamento, é fundamental priorizar os programas que ofereçam esse tipo de ferramenta.

De maneira geral, a estrutura básica para um processo de planejamento adequado é formada por pelo menos um programa com uma interface SIG que permita um bom manuseio dos dados, de modo a permitir atividades de cadastramento, visualização e análises primárias. Como complemento, sempre que possível deve-se considerar o uso de programas que possuam ferramentas mais elaboradas, que facilitem a execução de procedimentos mais trabalhosos sem exigir muitas adaptações. Isso ocorre, por exemplo, nos programas de SIG-T com interfaces SIG bem elaboradas, cujas ferramentas costumam abranger a maioria das atividades nas diversas áreas do planejamento urbano comuns em cidades de países em desenvolvimento (KHAN, 2007).

No caso do modelo aqui apresentado, são recomendados programas com ferramentas específicas para o planejamento de transportes, para que o modelo de demanda proposto possa ser executado sem a necessidade de muitos ajustes. Um exemplo, nessa categoria, é o programa VISUM (http://www.ptvag.com/software/ transportation-planning-traffic-engineering/software-system-solutions/visum/), que possui ferramentas específicas para a execução do modelo sequencial de demanda. Menos abrangente que o TransCAD, o VISUM oferece uma interface SIG menos elaborada, porém mais direcionada e intuitiva, como observado no What if?

De qualquer forma, num programa de abordagem mais geral, sem o foco no planejamento de transportes, contanto que se tenha uma interface SIG bem elaborada, ainda é possível executar os procedimentos do modelo de demanda. Porém, nesse caso torna-se necessária a configuração manual dos procedimentos e fórmulas, que no caso de programas como o TransCAD ou o VISUM, são executados automaticamente por suas ferramentas. Um exemplo de programa com excelente interface SIG é o ArcGIS (http://www.esri.com/software/arcgis/index.html), que oferece inúmeras ferramentas para manuseio de diversos tipos de dados, possibilitando as mais diferentes aplicações. Outro importante exemplo de SIG é o programa Spring (CÂMARA et al., 1996; http://www.dpi.inpe.br/spring/), que por ser 
desenvolvido no Brasil representa uma interessante alternativa para o planejamento urbano em cidades brasileiras.

\subsection{Adaptação e desenvolvimento de ferramentas e programas}

Independentemente dos programas escolhidos, a menos que tenham sido desenvolvidos exatamente para a execução dos modelos a serem empregados, normalmente será preciso adaptar suas ferramentas, através de determinados artifícios, ou ainda desenvolver novas ferramentas e até mesmo novos programas. Alguns exemplos de artifícios de adequação de dados e ferramentas foram apresentados anteriormente, como as hipóteses da figura 4.6 (Hipótese de equivalência entre número de viagens) e os procedimentos do item 5.1.3.3 (Método de divisão modal). É importante destacar que essas necessidades de adaptação foram consequências das limitações de disponibilidade de dados, mesmo quando o programa possuía ferramentas adequadas para realizar as respectivas etapas. Em ambos os casos, havia a opção de adequar os dados às ferramentas (como feito no primeiro caso, porém no segundo provavelmente exigira a obtenção de novos dados), ou às ferramentas aos dados (como no segundo caso, executando procedimentos externos em planilha eletrônica).

Percebe-se, portanto, que os recursos não podem ser encarados de forma isolada, já que são sempre relacionados e dependentes entre si. Sendo assim, é preciso dosar adequadamente os investimentos entre todos os recursos, seja na obtenção de dados, na aquisição ou desenvolvimento de programas, ou ainda na capacitação dos profissionais envolvidos. Dessa forma, é possível buscar processos mais viáveis na execução das atividades de planejamento. Nesse sentido, a obtenção de dados normalmente representa um fator pouco flexível nos países em desenvolvimento, pois está vinculada principalmente a questões tecnológicas. Torna-se então mais razoável manusear os dados já disponíveis de acordo com as alternativas possíveis de ferramentas e programas, incluindo aqueles disponíveis no mercado e os que possam vir a ser desenvolvidos.

Sabendo dessa necessidade de personalização de ferramentas, alguns desenvolvedores de programas disponibilizam meios (em alguns casos, até ferramentas específicas) que permitem a criação de novas ferramentas para seus programas. Através desse recurso, os programas podem ser complementados, 
evitando a necessidade de utilização de outros programas e procedimentos externos. Outra prática que vem ganhando espaço atualmente é o desenvolvimento compartilhado de programas, através da distribuição em código aberto (open source). Essa prática visa incentivar a troca de informações pelos interessados no desenvolvimento e uso dos programas, facilitando e incentivando esse processo, além de permitir que as ferramentas sejam largamente testadas e avaliadas. Isso promove o surgimento de ferramentas de maior qualidade e também mais adequadas para aplicações específicas, dado seu grande potencial de adaptação. Outra característica interessante dessa tendência é o acesso a diferentes alternativas entre programas e ferramentas, tornando-os mais acessíveis do ponto de vista financeiro. Considerando sua natureza de distribuição essencialmente gratuita, o fator financeiro exerce grande influência no momento da escolha das ferramentas. Isso ocorre tanto em relação à aquisição dos programas, quanto em relação ao treinamento necessário, já que muitos desses programas possuem material de apoio ao usuário disponível gratuitamente.

Essas atividades de adaptação e desenvolvimento de ferramentas e programas, porém, exigem alto nível de conhecimento técnico, tanto em relação à teoria envolvida nos modelos e métodos de planejamento, quanto em relação às atividades de programação. Tendo isso em vista, destaca-se a importância da proposta de modelos consistentes, com detalhes operacionais que auxiliem o trabalho dos planejadores e programadores nesse processo. Desse modo, o investimento na capacitação de profissionais deve assumir uma postura mais abrangente, incentivando a disseminação dos conhecimentos técnicos a fim de consolidar modelos e programas que atendam a necessidades e objetivos comuns.

\subsection{Aplicações e benefícios para o processo de planejamento}

Diante da pequena expressão do processo de planejamento como ferramenta de desenvolvimento urbano, percebe-se a necessidade de buscar meios competentes e promissores que incentivem a prática do planejamento, principalmente nas cidades médias de países em desenvolvimento. Devido ao fato de que, em muitas dessas cidades, é constante a incerteza e a baixa credibilidade dos dados e ferramentas de planejamento, pouco se tem investido na área. Nesse 
sentido, é preciso tratar o problema de forma mais abrangente, promovendo um processo gradual de conscientização e capacitação.

Através de estudos como os apresentados nesse trabalho, permite-se explorar a essência de dados e ferramentas típicos de cidades nas condições mencionadas. Informações desse tipo são fundamentais para a formação de conhecimento, assim como sua disseminação e aprimoramento. Dessa forma, é fundamental a participação das universidades e institutos de pesquisa, contribuindo com o desenvolvimento conjunto de soluções de caráter mais universal, dada a semelhança de comportamento das cidades com os mesmos padrões. Utilizando esses valiosos recursos de estudo e análise da consistência de modelos, justificam-se maiores investimentos no desenvolvimento de ferramentas e processos de autogestão, através da formação e treinamento de profissionais das diversas áreas envolvidas. Esses profissionais, atuando tanto num momento prévio de desenvolvimento, quanto posteriormente nas atividades de implantação e operação dos sistemas desenvolvidos, representam um potencial agente transformador da realidade atual do planejamento urbano.

Através do trabalho conjunto de planejadores, programadores e administradores públicos, tem-se o objetivo comum de construir argumentos confiáveis que orientem o processo de tomada de decisões, promovendo estruturas urbanas de maior qualidade. Esses argumentos precisam ser embasados em análises comparativas dos dados e cenários urbanos, para que se possam criar alternativas e avaliar as consequências de cada decisão. Desse modo é possível reverter a constante política de correção de problemas urbanos por uma política de prevenção de problemas urbanos. Essa prevenção pode ser realizada principalmente através de diretrizes de ocupação e uso do solo e diretrizes de implantação e operação do sistema viário e do sistema público de transportes. Dessa forma, modelos como o apresentado nesse trabalho configuram os principais meios de ação para realizar tais atividades.

Com o prosseguimento de estudos de tal natureza, pode-se determinar de forma mais abrangente as reais necessidades das cidades dos países em desenvolvimento. Esse processo tem como consequência a definição de diretrizes seguras para o desenvolvimento de ferramentas específicas para esse tipo de cidade. Com modelos e ferramentas adequadas, torna-se mais fácil padronizar as atividades de planejamento, trazendo diversos benefícios na coleta e cadastramento 
de dados, assim como na formação e capacitação de profissionais. Como resultado, o processo de planejamento torna-se mais organizado e acessível às diversas cidades, representando um recurso valioso capaz de promover um desenvolvimento mais inteligente e sustentável. 


\section{Capítulo 6 - Conclusões}

O processo de planejamento urbano desempenha um papel fundamental para o crescimento demográfico e econômico das cidades, particularmente em países em desenvolvimento. Nestes, a constante falta de planejamento acaba por ocasionar uma série de deficiências urbanas, como problemas de mobilidade e transporte. Apesar de tal importância, muitos governos deixam de investir no planejamento urbano devido à falta de recursos, informações e ferramentas capazes de tornar esse processo viável e eficaz. Mostra-se, contudo, neste trabalho, que é possível utilizar os recursos e informações comumente disponíveis nos países em desenvolvimento, através da adaptação ou criação de ferramentas com eles compatíveis. Essa abordagem tende a permitir a obtenção de previsões essenciais para a elaboração de alternativas e para a tomada de decisões quanto às políticas urbanas.

A metodologia aqui apresentada, aplicada na cidade de São Carlos, teve como objetivos: utilizar dados de fácil obtenção, executar procedimentos simples, baseados em hipóteses, e gerar resultados de fácil interpretação. Dessa forma, o estudo se mostrou amplamente promissor, demonstrando que é possível obter conclusões importantes para o processo de planejamento urbano, mesmo em países em desenvolvimento, com restrições de diversas naturezas (dados, recursos etc.). Tais conclusões podem ser abordadas tanto sob o ponto de vista específico da aplicação na cidade de São Carlos, quanto sob o ponto de vista operacional das ferramentas utilizadas.

\subsection{Conclusões sob o ponto de vista da aplicação}

Uma característica importante do modelo utilizado é que ele se limitou à manipulação dos dados já existentes. Ao evitar a aquisição de novos dados, contribuiu assim com a viabilidade do processo do ponto de vista prático. Para que os dados disponíveis fossem suficientes, no entanto, eles foram avaliados e trabalhados de modo a distinguir suas informações mais significativas, definindo hipóteses coerentes com a realidade da cidade. Um exemplo disso foi a utilização das viagens de trabalho para representar o conjunto geral de viagens diárias nos 
horários de pico, já que esse tipo de viagem constituía o mais representativo de acordo com as pesquisas observadas.

No processo de elaboração de hipóteses, notou-se a grande variabilidade de algumas características que influenciam diretamente o desenvolvimento da cidade. Esse fato, unido à incerteza quanto ao comportamento e a inter-relação de tais características, tornou necessária a criação de cenários hipotéticos de avaliação. Estes cenários permitem comparar resultados hipotéticos, inclusive aqueles gerados a partir de premissas bastante distintas. No caso estudado, os principais cenários apresentados permitiram comparar as perspectivas de desenvolvimento obtidas a partir do proposto no Plano Diretor e aquelas obtidas a partir da observação da situação real da cidade.

Para cada cenário, os resultados foram apresentados de forma visual e padronizada, através de mapas com escalas iguais e um mesmo sistema de cores e padrões gráficos. Dessa forma, é possível a comparação direta dos principais resultados dos diferentes cenários, dos quais se podem extrair informações de fácil interpretação e grande relevância. A análise dos mapas apresentados aponta uma grande diferença no padrão de crescimento dos cenários. Essa diferença evidencia a importância da consideração das distintas hipóteses em diferentes cenários, expondo de forma abrangente os possíveis impactos na cidade. Isso sugere inclusive possíveis linhas de ação para intervenção ou alterações nas futuras revisões do Plano Diretor.

Enquanto no primeiro cenário, que atende às diretrizes do Plano Diretor, o crescimento se deu praticamente todo na região noroeste da cidade, no segundo cenário, aquele que segue os padrões reais de desenvolvimento dos novos loteamentos, o crescimento se deu de forma distribuída. Isso influencia diretamente a demanda por viagens através da cidade, fazendo com que ela siga o padrão de ocupação encontrado. Porém, mesmo com ocupações bem diferentes, ambos os cenários apresentam uma grande concentração de viagens estimadas na área noroeste da cidade. A diferença é que, no primeiro cenário, essa região representa o eixo crítico de viagens, enquanto, no segundo, o eixo crítico se mantém na posição norte-sul, com grande concentração de viagens na região sul.

Quanto à grande diferença encontrada, é importante destacar que o primeiro cenário representa apenas a estrutura de ocupação que melhor se enquadra nas diretrizes do Plano Diretor e não a única capaz de atender às suas restrições legais. 
Além das diretrizes consideradas para a elaboração do primeiro cenário, o Plano Diretor possui outras informações (não utilizadas nesse trabalho já que não afetam as hipóteses adotadas para ambos os cenários apresentados), como a delimitação do perímetro urbano de São Carlos. Esse perímetro define a área total legalmente permitida para ocupação, independente das demais diretrizes que apenas sugerem áreas mais adequadas. Levando isso em conta, deve-se observar que o segundo cenário, assim como o primeiro, também se enquadra nas restrições legais do Plano Diretor, apesar de sua ocupação não seguir as demais diretrizes do plano.

Isso demonstra que o Plano Diretor não tem desenvolvido políticas de incentivo no sentido de promover a ocupação de acordo com suas diretrizes, admitindo grande flexibilidade no que diz respeito ao processo de ocupação urbana. Essa característica acaba permitindo que a ocupação ocorra de acordo com interesses pontuais que não fazem parte de uma política urbana integrada. Essa flexibilidade representa tanto uma consequência da falta de planejamento e controle da estrutura urbana, quanto um fator negativo no sentido de dificultar ainda mais esse processo, já que se torna mais difícil prever o comportamento urbano e, consequentemente, prover infraestruturas adequadas. Essa fraca política urbana resulta, portanto, na baixa qualidade do planejamento tanto da estrutura de ocupação, quanto das infraestruturas públicas.

Observando-se a situação atual da cidade de São Carlos, nota-se a grande quantidade de novos loteamentos aprovados ou em fase de aprovação, fornecendo uma enorme área disponível para ocupação. De acordo com os resultados do segundo cenário, pode-se dizer que apenas essas áreas são suficientes para comportar o crescimento esperado da cidade em um longo prazo. Mesmo ampliando o período de estudo do segundo cenário (2030) em 10 anos em relação ao primeiro (2020), nota-se que, ao fim do período, as áreas dos novos loteamentos não aparecem completamente ocupadas. Isso demonstra que, caso a cidade apresente um crescimento semelhante ao considerado na aplicação, as áreas sugeridas pelo Plano Diretor para expansão urbana só passariam a ser ocupadas após um período superior a 20 anos. Esse longo período evidencia a necessidade de revisão do plano, verificando os benefícios e custos para a cidade das possíveis configurações de ocupação e definindo diretrizes mais sólidas no sentido de promover e incentivar que o processo de ocupação ocorra de forma adequada. 
De qualquer forma, os resultados encontrados na aplicação do modelo proposto evidenciam a necessidade de uma atenção especial com relação à região noroeste da cidade. Independentemente do padrão de crescimento a ocorrer, essa região terá grande acréscimo de viagens em relação à situação inicial, a menos que as hipóteses de crescimento sejam bastante diferentes daquelas aqui apresentadas, o que provavelmente só ocorreria como conseqüência da implementação de políticas com esse fim. Desse modo, tem-se a oportunidade de avaliar, em conjunto com outras características da cidade, se esse perfil de viagens é desejado e qual a estruturação necessária para acomodá-lo, caso venha a ocorrer. Da mesma forma, as diferenças nos fluxos de viagens encontradas entre os cenários servem como base para sustentar futuras estratégias de ação, de acordo com os interesses da cidade.

Esse processo de construção de alternativas passíveis de análise e comparação configura uma das grandes vantagens de se utilizar modelos de simulação como esse. De posse dessas informações, têm-se argumentos que podem influenciar diretamente na definição de diretrizes, sejam de ocupação e uso do solo, sejam de implantação e operação do sistema de transportes. Nesse ponto, é importante destacar, dada a sua recíproca influência, a importância de se considerar conjuntamente as diretrizes de uso do solo e transportes. Com isso, o estudo torna possível prever os impactos de tais diretrizes antes que elas sejam de fato definidas e implantadas, promovendo assim um processo de planejamento integrado. Isso sugere que não apenas a cidade precisa se adequar ao crescimento, mas também o crescimento precisa se adequar à cidade.

\subsection{Conclusões sob o ponto de vista operacional}

Sob os aspectos operacionais, diversas conclusões puderam ser obtidas do estudo, configurando assim uma possível referência para estudos posteriores, tanto na cidade de São Carlos, quanto nas cidades típicas de países em desenvolvimento. Para que fosse possível transformar os dados existentes da cidade em resultados relevantes, utilizou-se do modelo convencional de demanda com sua estrutura sequencial. Esse método apresentou grande viabilidade, já que toda a estrutura de dados e ferramentas existentes, a que se teve acesso, se mostrou compatível com esse modelo de planejamento. Embora atualmente já complementada com outros 
métodos, sobretudo no ambiente acadêmico, essa estrutura sequencial se mostrou muito favorável para a proposta do presente trabalho. Isso se deve, entre outras coisas, à boa capacidade de organização dos dados conforme vão sendo trabalhados, facilitando sua operação e a execução de possíveis alterações.

Como ferramentas de base, mostraram-se fundamentais a interface SIG e as operações de planilha eletrônica, dentro ou fora do SIG. Com isso se faz possível analisar, organizar e trabalhar os dados, tanto estatisticamente quanto visualmente. Embora ainda pouco explorado em cidades pequenas e médias de países em desenvolvimento, apenas a capacidade de visualização de informações proporcionada pelo SIG já representa um recurso indispensável para o planejamento urbano. Já as operações de planilha eletrônica se mostram indispensáveis para o processamento de qualquer modelo de grande escala, como no caso dos estudos urbanos.

As demais ferramentas são também importantes, porém, de forma geral, atuam como agentes operacionais, executando procedimentos trabalhosos de forma automática. Essa simplificação é, contudo, importante, visto que tais procedimentos, além de trabalhosos, são executados repetidas vezes, dada a necessidade de projeção em diferentes cenários. Nesse sentido, deve-se observar a importância da verificação e conferência dos resultados processados de forma automática pelas ferramentas. Do mesmo modo que essas ferramentas reduzem drasticamente o tempo de trabalho necessário, dedicar a elas uma etapa que garanta a sua correta utilização, sem dúvida, reduz o tempo necessário para identificar, encontrar e corrigir possíveis erros.

Essa idéia se aplica, de forma mais geral, à utilização de programas computacionais adquiridos para o processamento dos modelos. Os programas são conjuntos de ferramentas previamente desenvolvidas e testadas, reunidas para permitir o adequado processamento de funções, de acordo com objetivos cuja demanda justifique um processo de sistematização. A vantagem de se fazer uso de programas comerciais é dispensar a necessidade de desenvolver todas as ferramentas que se deseje utilizar no processo. Esse desenvolvimento exige maiores níveis de conhecimento e demanda grande quantidade de tempo, porém substitui o investimento em programas prontos que muitas vezes podem não corresponder totalmente às expectativas dos modelos empregados. 
De acordo com Khan et al. (2007), a utilização de programas largamente testados, além de eliminar a necessidade de programação, ajuda a reduzir o risco de problemas no sistema. De qualquer forma, utilizar programas prontos não extingue a necessidade de conferência dos resultados obtidos nas ferramentas. Existe sempre a possibilidade de erros, tanto de natureza específica, não previstos no desenvolvimento dos programas, quanto de natureza operacional, na entrada e manipulação dos dados. No segundo caso, mostra-se fundamental a realização de processos de calibração, adequando os modelos para que representem o mais fielmente possível a realidade da cidade.

Quanto aos programas utilizados na aplicação, pode-se dizer que o TransCAD se mostrou perfeitamente capaz de executar a grande maioria das etapas necessárias para organização dos dados iniciais, assim como a obtenção e apresentação dos resultados. É um programa bem abrangente, com diversas opções de ferramentas. Como pontos desfavoráveis, podem-se destacar seu considerável nível de complexidade e a quantidade excessiva de ferramentas em grande parte desnecessárias para o método proposto. Apesar disso, com algum treinamento prévio, é um programa altamente recomendado para processos de planejamento que se utilizem da mesma sistemática aqui demonstrada.

Já o programa What If?, com sua estrutura mais simplificada, proporcionou um processo simples e intuitivo, complementando os poucos pontos onde 0 TransCAD não se mostrou suficiente. Apesar de sua estrutura simplificada, muitos atributos de suas ferramentas também não foram necessários no estudo realizado. Diferentemente do TransCAD, o What If? se mostrou ainda relativamente instável na utilização de algumas ferramentas. Quanto a isso, uma grande vantagem do estudo foi a possibilidade de manter contato direto com os desenvolvedores do programa, o que forneceu um valioso suporte na solução de eventuais erros.

Outra desvantagem da utilização de programas comerciais é a provável necessidade de mais de um programa para que se possam abranger todas as ferramentas demandadas pelo método. Isso aumenta o nível de investimento inicial, podendo muitas vezes tornar o processo inviável. E embora demonstrado em Rodrigues da Silva et al. (2009) que os programas TransCAD e What If? apresentam um baixo nível de vinculação e boa compatibilidade operacional, ainda assim o diálogo entre ambos apresentou problemas em alguns dados. Isso mostra outra 
vantagem da utilização de um pacote único que contenha todas as ferramentas necessárias.

De acordo com a análise das ferramentas utilizadas, a grande maioria delas apresenta, ao mesmo tempo, a presença de funcionalidades desnecessárias e a ausência de funcionalidades que contribuiriam para uma execução mais eficiente e realista do modelo empregado. Por se tratarem de programas comerciais, diminui-se a possibilidade de otimizar as ferramentas para as necessidades específicas do modelo, fazendo com que os únicos meios de intervenção sejam através de ferramentas ou programas adicionais, dificultando ainda mais o processo. Percebe-se que um grande conhecimento das ferramentas unido a uma boa capacidade de interação no processo contribui para o desenvolvimento de modelos cada vez mais efetivos. Isso tudo mostra o quanto se torna desejável um maior contato entre os planejadores, programadores e tomadores de decisão.

Fica, assim, clara a importância de reunir ferramentas funcionais que trabalhem bem em conjunto e que sejam apropriadas às hipóteses e modelos considerados. Somente com um conjunto adequado de ferramentas se mostra possível lidar com as restrições encontradas nos países em desenvolvimento e promover um processo de planejamento sólido e viável.

\subsection{Sugestões para trabalhos futuros}

Um dos principais objetivos desse trabalho é fornecer argumentos de base para aplicações de um modelo de simulação que auxilie o processo de planejamento urbano nas cidades médias de países em desenvolvimento. Nesse sentido, apesar das semelhanças, entende-se que cada cidade possui suas próprias características quanto à obtenção de dados, utilização de ferramentas e políticas de administração pública. Portanto, para que o modelo proposto seja cada vez mais acessível e confiável, são necessárias diversas atividades no sentido de aprimorá-lo e testá-lo sob diversos aspectos. Tais atividades são perfeitamente associáveis a trabalhos futuros, que podem ser categorizados de acordo com suas diferentes abordagens possíveis. 


\subsubsection{Calibrações e verificações de hipóteses}

O modelo proposto, assim como sua aplicação na cidade de São Carlos, foi sugerido de forma simplificada, não tendo priorizado a verificação precisa dos resultados obtidos. Entretanto, com o intuito de tornar o modelo mais realista, é possível aplicá-lo de modo a comparar seus diversos dados estimados com informações reais contabilizadas na cidade. Através de tais comparações, podem-se identificar parâmetros mais realistas e verificar a veracidade das hipóteses adotadas. $\mathrm{Na}$ aplicação apresentada, algumas verificações e calibrações foram realizadas, porém, há espaço para muitas outras.

Algumas sugestões são: comparar os valores populacionais estimados para as zonas de análise com os valores dos novos levantamentos censitários do IBGE; contabilizar o número total de viagens estimadas pelo modo ônibus e comparar com o número real de passageiros transportados; contabilizar o fluxo veicular real nas principais vias arteriais e comparar proporcionalmente com os fluxos estimados (levando em conta o número de passageiros por veículo); calibrar a fórmula responsável por estimar as distâncias das viagens internas às zonas de análise através dos dados da Pesquisa O/D; comparar as matrizes O/D geradas pelo modelo com as matrizes geradas pelos dados da Pesquisa O/D; verificar se a hipótese de utilizar somente as viagens de trabalho permanece válida para futuras Pesquisas O/D.

Além disso, outras hipóteses mais realistas podem ser adicionadas ao modelo, auxiliando ou substituindo hipóteses mais simplificadas caso isso se mostre viável e contribua com a qualidade do modelo. Algumas dessas hipóteses poderiam ser: distribuir as viagens pelos modos de transporte, considerando as diferentes demandas para cada modo em cada zona de análise, ou utilizar um método de escolha modal mais elaborado; distribuir os fluxos de viagens utilizando outros métodos de alocação, considerando a capacidade das vias; considerar as distâncias entre zonas através da rede viária, ao invés das distâncias em linha reta; verificar as hipóteses de considerar outros tipos de viagens, como viagens de trabalho específicas no setor institucional e estudos. 


\subsubsection{Aplicações com diferentes ferramentas}

Outra categoria de possíveis trabalhos futuros consiste em realizar aplicações semelhantes à aqui apresentada, porém utilizando diferentes ferramentas. Com isso, podem-se comparar os resultados obtidos através de diferentes ferramentas ou conjuntos de ferramentas, avaliando seus desempenhos, limitações e principais vantagens e desvantagens. Esse processo seria útil tanto no sentido de fornecer mais opções de ferramentas para a execução do modelo em futuras aplicações, quanto para avaliar o desempenho do próprio modelo, observando a consistência dos resultados e procurando possíveis erros. Dependendo das ferramentas escolhidas, diferentes hipóteses podem ser necessárias para adequá-las aos dados disponíveis, de acordo com suas funcionalidades e procedimentos exigidos para executar as etapas do modelo. Um conjunto interessante de ferramentas é a utilização de um programa SIG de interface simples e um programa de planilha eletrônica, onde seriam desenvolvidas todas as fórmulas e procedimentos do modelo, representando um processo trabalhoso, porém de grande relevância para o aprimoramento do modelo.

Além de testar ferramentas disponíveis, uma das importantes sugestões desse trabalho é utilizar as informações operacionais reunidas com a análise da aplicação do modelo apresentada para auxiliar o processo de desenvolvimento de novas ferramentas e programas. Com base nas necessidades e limitações encontradas, é possível saber os pontos que precisam ser aprimorados, o que contribui para o desenvolvimento de ferramentas adequadas ao modelo. Esse enfoque sugere trabalhos interdisciplinares entre as áreas de planejamento urbano e de transportes e as áreas de computação. É também interessante o desenvolvimento de ferramentas auxiliares ao processo de planejamento, como ferramentas para a realização de pesquisas e obtenção de dados. Um exemplo desse tipo de ferramenta seria uma página na internet para reunir informações dos usuários de transporte, auxiliando a verificação de tendências e avaliando a qualidade do sistema.

\subsubsection{Aplicações em diferentes cidades}

Finalmente, buscando a consolidação do modelo e sua confiável e eficiente utilização em outras cidades, sugere-se realizar aplicações como a apresentada, em 
diferentes cidades médias de países em desenvolvimento, fazendo uso das mesmas fontes de dados ou de fontes compatíveis e de ferramentas e programas acessíveis. Existe também a possibilidade de testar o modelo para outros tipos de cidades, verificando sua relevância para seus respectivos processos de planejamento urbano e de transportes. Esse tipo de estudo, promovendo a aplicação do modelo em diferentes cidades, representa seu enfoque mais abrangente. Ele envolve todas as características do modelo, desde as restrições de dados e ferramentas até as estratégias de planejamento de cada cidade, tendo impactos diretos sobre o tipo de informações geradas e a forma de análise dos resultados.

A comparação de resultados entre cidades distintas é mais complexa devido às possíveis diferenças tanto nas hipóteses a serem consideradas, quanto na forma dos resultados almejados. Quanto a isso, cidades de configurações urbanas e políticas semelhantes apresentam maiores chances de possuírem dados passíveis de comparação. De qualquer forma, sempre que possível a análise comparativa dos dados gerados por aplicações em duas ou mais cidades representa uma forma importante de compreensão do modelo, agregando conhecimento sobre suas principais variáveis e procedimentos. Esse conhecimento pode ser usado tanto para aprimorar o modelo, quanto para fornecer parâmetros de base para cidades que não possuam dados suficientes para calibrar determinados valores necessários, além de auxiliar e incentivar processos de planejamento de maior qualidade. 


\section{Referências bibliográficas}

AGYEMANG-DUAH, K.; HALL, F. L. Spatial transferability of an ordered response model of trip generation, Transportation Research Part A: Policy and Practice, v. 31, n. 5, 389-402, 1997.

AL-KODMANY, K. Using visualization techniques for enhancing public participation in planning and design: process, implementation, and evaluation. Landscape Urban Planning, v. 45, 37-45, 1999.

ANDERSON, M. D.; OLANDER, J. P. Evaluation of two trip generation techniques for small area travel models. Journal of Urban Planning and Development, v. 128, n. 2, 77-88, 2002.

ANDERSON, M. D.; SHARFI, K.; GHOLSTON, S. E. Direct demand forecasting model for small urban communities using multiple linear regression. Transportation Research Record: Journal of the Transportation Research Board, v. 1981, 114-117, 2006.

BRASIL, Estatuto da Cidade, Lei 10.257 de 10 de julho de 2001, Diário Oficial Eletrônico, 11/07/2001, p. 1, 2001.

CÂMARA, G.; SOUZA, R. C. M.; FREITAS, U. M.; GARRIDO, J. Spring: Integrating remote sensing and GIS by object-oriented data modeling. Computers \& Graphics, v. 15, n. 6, 13-22, 1996.

CLARKE, K. C.; GAYDOS, L. J. Loose-coupling a cellular automaton model and GIS: long-term urban growth prediction for San Francisco and Washington/Baltimore. International Journal of Geographical Information Science, v. 12, n. 7, 699-714, 1998.

EMMELIN, L. Landscape impact analysis: a method for strategic environmental impact analysis, In: SCHOUTE, J. F. T.; FINKE, P. A.; VEENEKLAAS, F. R.; WOLFERT, H. P. (Eds.). Scenario Studies for the Rural Environment, Kluwer Academic Publishers, 449-454, 1995.

EOM, J. K. Incorporating activity-based special generator data into a conventional planning model. (PhD Dissertation), Raleigh: Graduate Faculty of North Carolina State University, 2007.

EWING, R.; DEANNA, M.; LI, S. Land use impacts on trip generation rates, Transportation Research Record, v. 1518, 1-7, 1996. 
FERRAZ, A. C. P.; TORRES, I. G. E. Transporte Público Urbano. São Carlos: Rima, 2004.

HAN, Y. Synthesized through-trip models for small and medium urban areas. Transportation Research Record: Journal of the Transportation Research Board, v. 2077, 148-155, 2008.

HAN, Y.; STONE, J. R.; HUNTSINGER, L. F. Manual traffic allocation for small-town networks. Transportation Research Record: Journal of the Transportation Research Board, v. 1997, 24-34, 2007.

HARMS, W. B. Scenarios for nature development, In: SCHOUTE, J. F. T.; FINKE, P. A.; VEENEKLAAS, F. R.; WOLFERT, H. P. (Eds.). Scenario Studies for the Rural Environment, Kluwer Academic Publishers, 391-403, 1995.

HARRIS, B. Urban simulation models in regional science. Journal of Regional Science, v. 25, 545-568, 1985.

HENSHER, D. A.; BUTTON; K. J., HAYNES, K. E. Handbook of transport geography and spatial systems. Amsterdam: Elsevier, 2004.

HOBSBAWM, E. J. Da revolução industrial inglesa ao imperialismo. Rio de Janeiro: Forense Universitária, 2003.

HUNT, J. D.; MILLER E. J.; KRIGER D. S. Current operational urban land-use transport modeling frameworks, Transport Reviews, v. 25, n. 3, 329-376, 2005.

IBGE, Instituto Brasileiro de Geografia e Estatística, Censo, 2000. [http://www.ibge.gov.br/].

JENKS, M.; JENKS, M.; BURGESS, R. Compact cities: sustainable urban forms for developing countries. London: E. \& F. N. Spon, 2000.

JOHNSTON, R. A.; DE LA BARRA, T. Comprehensive regional modeling for longrange planning: linking integrated urban models and geographic information systems. Transportation Research Part A: Policy and Practice, v. 34, n. 2, 125-136, 2000.

KANAFANI, A. K. Transportation Demand Analysis. Berkeley: McGraw-Hill, 1983. 
KAWAMOTO, E. Análise de Sistemas de Transportes. São Carlos: Universidade de São Paulo, Escola de Engenharia de São Carlos, Departamento de Transportes, 2004. Notas de aula.

KHAN, A. M.; ARMSTRONG, J. M.; TAYLOR, S. J. Urban transportation planning and management in a GIS environment. Journal Alam Bina, v. 9, n. 1, 109-129, 2007.

KLOSTERMAN, R. E. An introduction to the literature on large-scale models. Journal of the American Planning Association, v. 60, n. 1, 41-44, 1994.

The What if? planning support system. In: BRAIL, R. K.; KLOSTERMAN, R. E. (Eds.). Planning Support Systems: Integrating Geographic Information Systems, Models and Visualization Tools, eds., Redlands: ESRI, 263-284, 2001.

A new tool for a new planning: The What if? planning support system. In: BRAIL, R. K. (Ed.) Planning Support Systems for Cities and Regions. Cambridge: Lincoln Institute of Land Policy, 85-99, 2008.

KLOSTERMAN, R. E.; XIE, Y. Retail impact analysis with loosely coupled GIS and a spreadsheet. International Planning Studies, v. 2, n. 2, 175-192, 1997.

LIMA, R. S. Expansão Urbana e Acessibilidade - o caso das cidades médias brasileiras. Dissertação (Mestrado), São Carlos: Universidade de São Paulo, Escola de Engenharia de São Carlos, 1998.

LOPES, R. A cidade intencional: o planejamento estratégico de cidades. Rio de Janeiro: Mauad, 1998.

MANZATO, G. C. Regiões urbanas homogêneas e oferta de transportes. Dissertação (Mestrado), São Carlos: Universidade de São Paulo, Escola de Engenharia de São Carlos, 2007.

MASSER, I.; CAMPBELL, H. Conditions for the effective utilization of computers in urban planning in developing countries. Computers, Environment and Urban Systems, v. 15, n 1-2, 55-67, 1991.

MOHAMMADIAN, A.; ZHANG, Y. Investigating Transferability of National Household Travel Survey Data. Journal of the Transportation Research Record, v. 1993, 67-79, 2007. 
ORLAND, B.; BUDTHIMEDHEE, K.; UUTSITALO, J. Considering virtual worlds as representations of landscape realities and as tools for landscape planning. Landscape Urban Planning, v. 54, 139-148, 2001.

ORTÚZAR, J. de D.; WILLUMSEN, G. Modelling transport. London: Wiley, 2006.

PREFEITURA MUNICIPAL DE SÃO CARLOS. Cadastro de novos loteamentos aprovados ou em fase de aprovação. Arquivos eletrônicos. São Carlos, 2010.

RAIA JÚNIOR, A. A. Uma avaliação do modelo META para cálculo de custos de transportes e seu uso na tributação de terrenos urbanos ociosos. Dissertação (Mestrado), São Carlos: Universidade de São Paulo, Escola de Engenharia de São Carlos, 1995.

ROCHA, G. R.; OLBRICK, M. R.; RODRIGUES DA SILVA, A. N. Relações entre características das áreas urbanas e das linhas de transporte coletivo urbano, $16^{\circ}$ Congresso Brasileiro de Transporte e Trânsito, Associação Nacional de Transportes Públicos - ANTP, 2007.

RODRIGUES DA SILVA, A. N. Sistemas de Informações Geográficas para Planejamento de Transportes. Tese (Livre docência), São Carlos: Universidade de São Paulo, Escola de Engenharia de São Carlos, 1998.

Elaboração de um banco de dados de viagem para auxílio ao desenvolvimento de pesquisas na área de planejamento dos transportes. São Carlos: Universidade de São Paulo, Escola de Engenharia de São Carlos, Relatório FAPESP, Processo No 04/15843-4, 2008.

RODRIGUES DA SILVA, A. N.; ROCHA, G. R.; KLOSTERMAN, R. E. A looselycoupled planning support system for transportation sketch planning. International Conference of Computers in Urban Planning and Urban Management (CUPUM), Hong Kong, 2009.

SANTOS, M. A urbanização brasileira. São Paulo: Editora da Universidade de São Paulo (EdUSP), 2008.

SÃO CARLOS, Plano Diretor do Município, Lei No 13.691/05 de 25 de Novembro de 2005, Diário Oficial do Município, São Carlos, 2005.

SCHRANK, D. L. Developing a sketch-planning technique relating economic activity and urban mobility in small and medium-sized urban areas. College Station: The Southwest Region University Transportation Center, Texas Transportation Institute, The Texas A \& M University System, 2004. 
SEADE, Fundação Sistema Estadual de Análise de Dados, Dados de São Carlos, 2009.

[http://www. seade.gov.br/].

SINGH, R.R. Exploiting GIS for sketch planning. 1996 ESRI International User Conference, Palm Springs, 1996.

SMEED, R. J. The road capacity of city centers. Highway Research Records, v. 169, Washington D. C., 22-29, 1967.

SMITH, J.; SAITO, M. Creating land-use scenarios by cluster analysis for regional land-use and transportation sketch planning. Journal of Transportation and Statistics, v. 4, n. 1, 39-49, 2001.

TRESS, B.; TRESS, G. Scenario visualization for participatory landscape planning - a study from Denmark. Landscape and Urban Planning, v. 64, 161-178, 2003.

ULTRAMARI, C.; REZENDE, D. A. Planejamento estratégico e planos diretores municipais: referenciais e bases de aplicação. Revista de Administração Contemporânea, v. 12, n. 3, 717-739, 2008.

VASCONCELLOS, E. A. Transporte urbano nos países em desenvolvimento: reflexões e propostas, São Paulo: Annablume, 2000.

WEGENER, M. Urban land-use transportation models. In: MCGUIRE, D.; BATTY, M.; GOODCHILD, M. (Eds.). GIS spatial analysis and modeling. Redlands: ESRI, 203-220, 2005.

WOLLENBERG, E.; EDMUNDS, D.; BUCK, L. Using scenarios to make decisions about the future: anticipatory learning from the adaptive co-management of community forests. Landscape Urban Planning, v. 47, 65-77, 2000. 